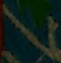

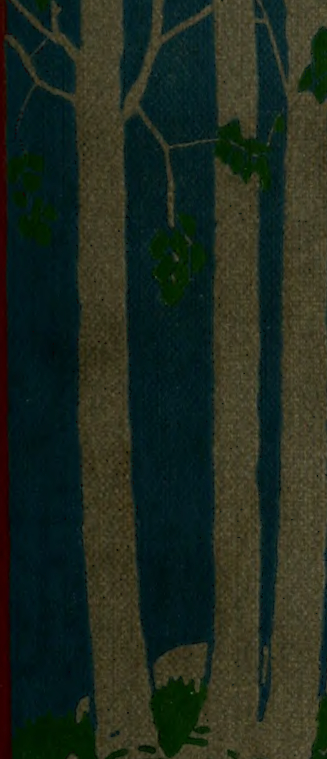

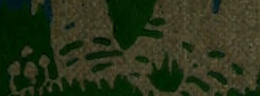

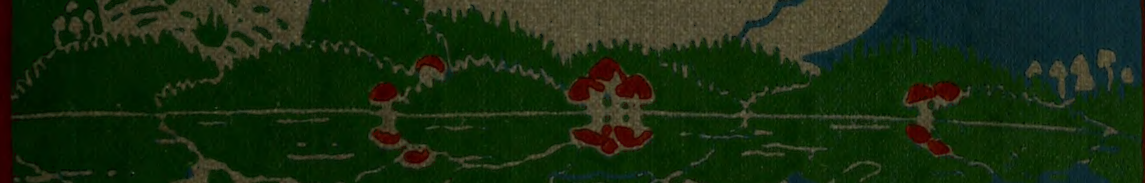

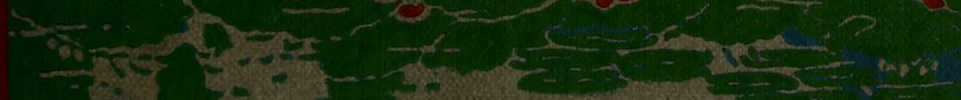

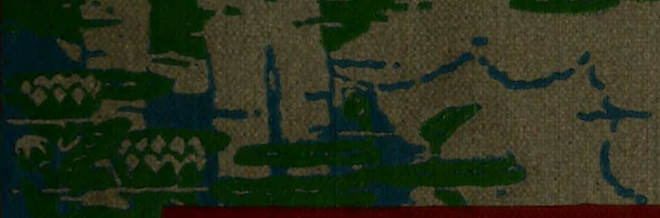

2. AGNES GIBERNE 


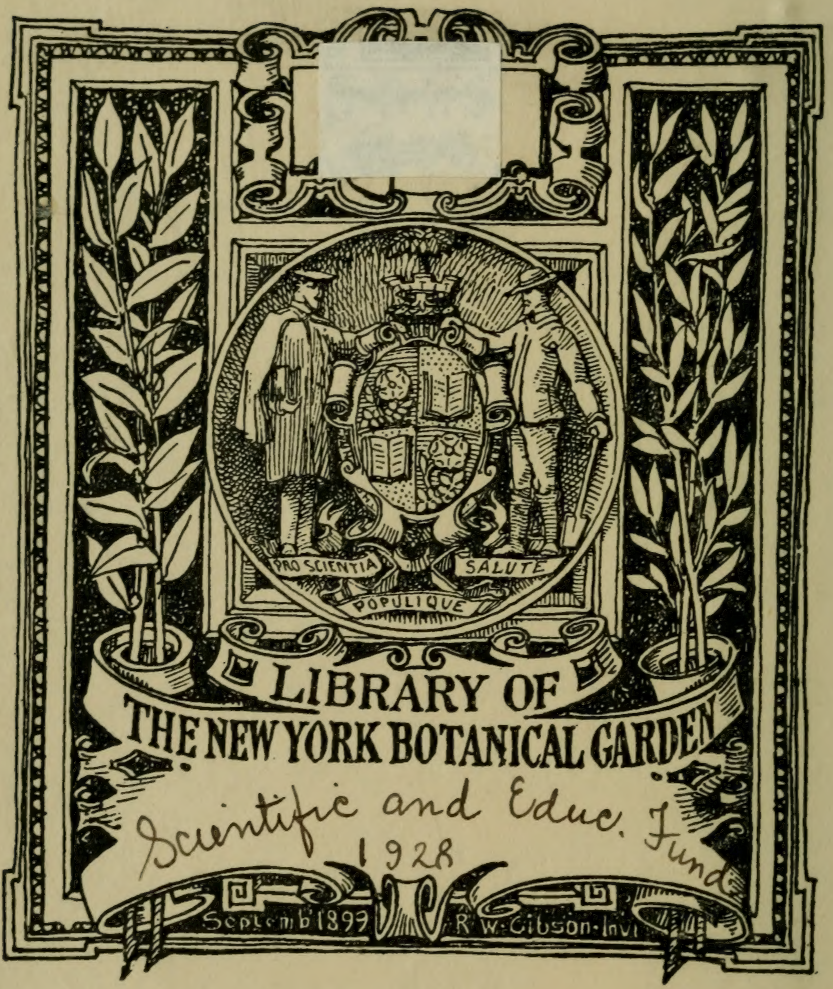




THE GARDEN OF EARTH 


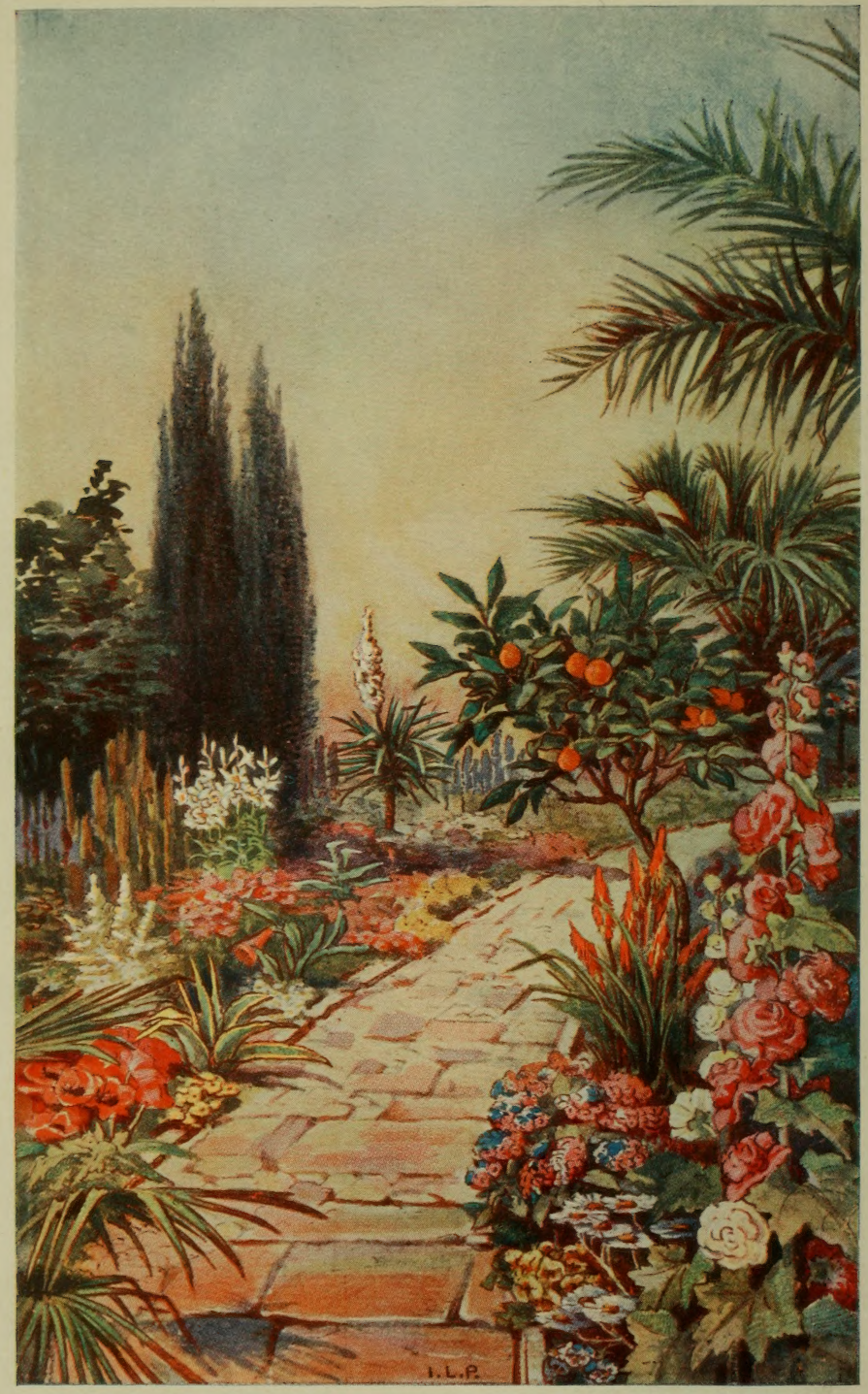

A Sub-tropic Garden. 


\title{
THE
}

\section{GARDEN OF EARTH}

A Little Book on Plant-life, Plant-growth, and the $W$ ays and Uses of Plants

\author{
BY \\ AGNES GTIBERNE \\ AUTHOR OF \\ "THIS WONDERFUL UNIVERSE," "THE ROMANCE OF THE MightY DEEP," ETC.
}

"When Spring unlocks the Flowers to paint the laughing soil."-Reginald Heber.

"O then indeed I knew how closely knit

To Stars and Flowers we are."-Alfred Noyes.

With Coloured Frontispiece and Illustrations

\author{
LONDON
}

SOCIETY FOR PROMOTING

CHRISTIAN KNOWLEDGE NEW YORK : THE MACMILLAN COMPANY 
Uniform with this Volume-by the same Author

\section{THIS}

\section{WONDERFUL UNIVERSE}

A little book about suns and worlds, moons and meteors, comets and nebulæ. New edition completely re-written. With coloured Frontispiece, and numerous other Illustrations. Cloth boards. $6 s .6 d$. net.

LONDON : S.P.C.K. 


\section{FOREWORD}

IT does not fall to the lot of most people to be able to devote much time to Botany. This book does not pretend to be even an introduction to that delightful pursuit. Given, however, a certain admiration for the beauties of the garden and countryside, Miss Giberne's book is calculated to enlarge it into a feeling of friendship for the individuals of the vegetable kingdom. The authoress gracefully draws aside the veil and shows the wind, the bees, and the flowers at play. The reader is encouraged to step among them, and to look for himself.

Any one who had been content with the usual superficial observation of Nature, and who is hereby introduced into an intimate acquaintance with the game and with its players, will have to thank this book for a new and very charming friendship with the animated but previously unnoticed world around him.

S. T. Dunn, B.A. Formerly Official Guide in the Royal Botanic Gardens, Kew. 



\section{PREFACE}

As unpretentious little volume, on the subject of Plant-life and the ways and needs and doings of Plants, is all that my book can claim to be. It is, indeed, in no sense a Manual of Botany; and it is meant for beginners, whether older or younger, as well as for any who love and are interested in trees and flowers.

In the writing of it I have gained needed information from many different sources; more especially from The Natural History of Plants, by Kerner and Oliver. Also generous help has been given to me by Mr. S. T. Dunn of the Kew Gardens Staff, for which I am sincerely grateful. Nor can I refrain from a warm mention of the debt which I owe to my Father's early and unforgettable teachings on this subject.

In addition I thank Mr. Alfred Noyes, Mr. John Masefield, and other poets of the day whose names appear in footnotes, as well as their publishers, for kind permission to quote from their writings.

Many gardens, large and small, are in the world; and our whole Earth may fairly be described as one vast Garden, with its more beautiful and its more barren parts. I have tried to bring some glimpses, some visions, of that Garden and of what it really means, before the imagination of my readers.

This is intended to be a companion-volume to another vii 
of mine, published a few months ago; nominally a reprint from a small volume of the same name, but entirely rewritten. I wonder whether, possibly, some who have read This Wonderful Universe, may now turn to The Garden of Earth with the feeling described by Mr. Alfred Noyes in one of his poems :-

"We should come

Seeking a little refuge from the light

Of the blinding terrible star-sown Infinite, Seeking some sheltering roof, some four-walled Home, From that too high, too wide

Communion with the Universe and God, How glad to creep back to some lane we trod, Hemmed in with a hawthorn hedge on either side."

Yet the marvels and the mysteries to be found in that hawthorn hedge are not less than the marvels and the mysteries of the Star-sown Universe, as seen and known in ever so limited a measure by us on Earth.

Agnes Giberne. 


\section{CONTENTS}

\section{PART I-INTRODUCTORY}

THE SPRING AWAKENING PAGE

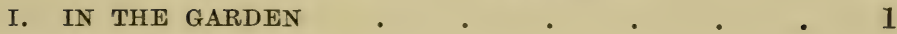

II. MANY PLANTS • . . . . . . 3

III. WHAT THE PLANTS ARE DOING • • . . 6

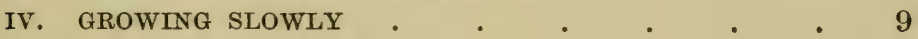

\section{PART II}

THINGS GREEN AND FAIR

I. A GOOD LOOK ROUND $\quad$. $\quad$. $\quad$. $\quad$. 13

II. PLANTS AND ANIMALS . . . . . 15

III. THE PARTS OF A PLANT . . . . . 17

IV. THE PARTS OF A FLOWER . . . . . 21

\section{PART III}

A WIDE WORLD OF PLANT-LIFE

I. NAMES AND NATURES . . . . . . 26

II. SUCH NUMBERS! . . . . . $\quad$ • 29

III. A LADDER OF LIFE . . . . . . 32

IV. SOME CURIOUS DIFFERENCES . . . . 39 


\section{PART IV}

FAMILY RELATIONSHIPS

PAGE

I. PUT INTO CLASSES • • . • • • 44

II. ROSES AND THEIR RELATIVES • • • • 48

III. "BUTTERCUPS AND DAISIES" • • • • 53

\section{PART V}

THE WORK OF ROOTS AND STEMS

I. WHAT SOIL IS MADE OF • • . . . 61

II. THE WORK OF WORMS . • . . . 64

III. GROWING UP AND GROWING DOWN • • 66

IV. TIPS AND HAIRS . . . . . . 68

V. A PLANT'S BRAIN . . . . . . 73

\section{PART VI}

THOSE LITTLE WORKSHOPS

I. THE RISING OF SAP • . . . . . 76

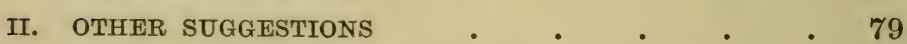

III. HOW MANY LEAVES ? $\quad$ • $\quad$ • $\quad$ • $\quad$ • 82

IV. THE MAKE OF A LEAF- . . • • • 85

V. AND THE WORK OF A LEAF • • • • 88

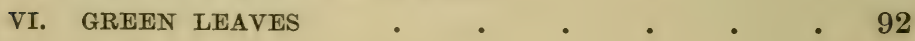

\section{PART VII}

THE POWER OF SUNLIGHT

I. FLOWERS IN SUNSHINE $\quad$ • $\quad$ • $\quad$ • $\quad$ • 96

II. HOW THE WORK IS DONE . . . . 100

III. PLANT MANUFACTURES • . . . 103

IV. THE FOOD THAT WE EAT • . . . . 105

V. OCEAN-FOOD . . . . . . . 110 


\section{PART VIII}

THE WORK OF. FLOWERS

I. WHAT FLOWERS ARE FOR .

- 114

II. PISTILS AND STAMENS

III. HOW THE SEEDS GROW 120

IV. PLANT STORAGE . . . . . . 124

V. MAKING READY FOR SUMMER . . . . 127

vi. SEED-SCATTERING $\quad$ • . . . . . 132

\section{PART IX}

THE WORK OF WINDS AND INSECTS

I. POLLEN TO THE PISTIL • . • • • 137

II. HOW DOTH THE BUSY BEE . • • 143

III. CURIOUS CONTRIVANCES . . . . 150

\section{PART $\mathrm{X}$}

SOME REMARKABLE WAYS OF PLANTS

I. PLANT MOVEMENTS • • • • • . 157

II. SENSITIVE AND MEAT-EATING PLANTS $\quad . \quad 160$

III. THE HEALTH OF PLANTS • . . . 167

IV. PLANT-LIFE IN GENERAL • . . . $\quad$. 171 



\section{LIST OF ILLUSTRATIONS}

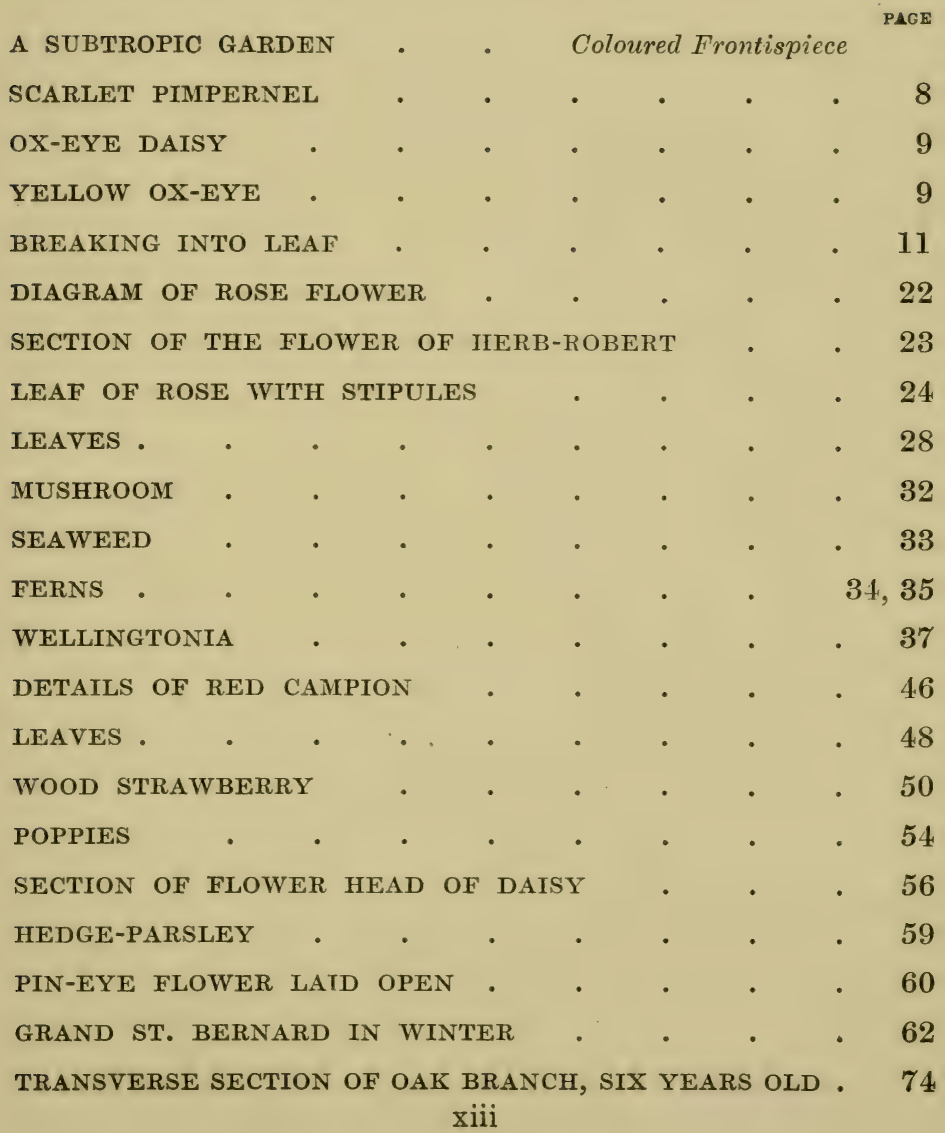


GOVERNOR ODELL AND PARTY . . . . . 77

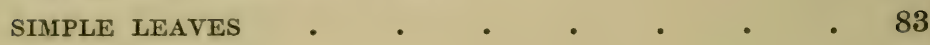

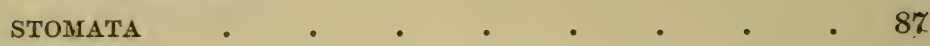

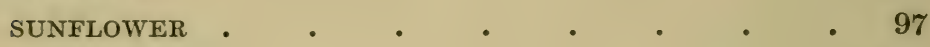

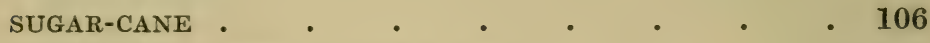

BANANAS AND THE SUGAR-CANE • . . . 107

COCOA • • .

COTTON .

RAFFLESIA FLOWER • . . . . . . 115

FLOWER OF THE COMMON ASH; STAMEN, ANTHER, ETC. 121 SNOWDROP SHOWING STEM, FLOWER AND ROOT • • 126

VARIETIES OF FRUIT • • • • • • • • 132

FLOWERS OF OAK • . . . . . . . 133

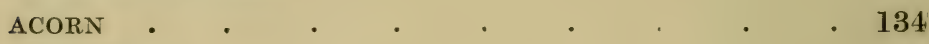

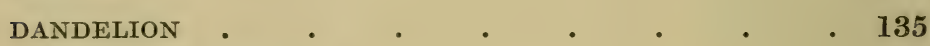

CATKINS OF THE OAK . . . . . . 140

STAMINATE AND PISTILLATE CATKINS OF A WILlOW • 141

POLLINATION BY BEE • • • • • • • • 145

VALLISNERIA SPIRALIS . . . . . . 151

BLADDERWORT . . . . . . 163,164

PITCHER PLANT • . . . . . . 165

SUNDEW . $\quad . \quad$. $\quad . \quad$. 166 


\title{
THE GARDEN OF EARTH
}

\section{PART I-INTRODUCTORY}

\author{
THE SPRING AWAKENING
}

\section{I-IN THE GaRDEN}

Suppose that you and I are going into a large garden, for the first time in our lives. It might be that we had lived always in some huge manufacturing town, where trees could not grow, and flowers could not flourish. Or-if this were possible-that our lot had been cast in far-north regions of perpetual ice and snow, where vegetation would be only of the very lowest.

What, then, should we think of a fair garden, breaking suddenly on our sight in spring? How much should we understand, how much should we grasp, of what would lie before our eyes?

Picture it to yourself, and try to realise how things would look. Come into the garden, in imagination, and make yourself see as you would see under such circumstances, with eyes unused, with a mind unaccustomed, to the surroundings. Countless marvels in this world we accept with calm indifference, only because we have always known them thus. Otherwise, we should be perpetually stirred to wonder and amazement at 
the sights around, the changes which take place, the things which happen.

So here we are in a country garden, you and I together, let us say, for the first time in our lives.

On our left lies a wide lawn, closely mown, but dotted with hundreds of yellow-eyed Daisies, all sprung up since the last mowing. On our right, divided off by a dry ditch, is a reach of longer and coarser grass, mingled plentifully with weeds; and it slopes downward to a meadow, from which it is parted by a belt of shrubs and bushes.

Trees grow in all directions; some small and slender, swaying in the breeze; some lofty and wide-spreading, with heavy, rugged trunks. Many are full of leaf, though not yet so full as in the height of summer; for this, though a warm and sunny day, is only springtide. Others have still the first tender flush of green, when the new little leaves have just begun to unfold. Many again are quite bare, holding up against the sky a lace-work of delicate twigs, branching off and off one from another, each new departure more delicate than the last.

You and I know well enough that plants and flowers grow and bloom and die; that leaves fall off the trees in autumn; that new leaves come in their place with spring; that seeds are formed which develop into fresh plants; and that those plants again produce seeds. Everybody knows all this, because such facts are a commonplace of our daily life.

But suppose we did not know it! Suppose we had never seen, had never even heard of, such alternate generations of plant and seed, seed and plant, each 
succeeding the other. Or suppose that, while in a sense knowing it, we had never given the matter any serious thought, had never cared to learn how such wonders come about.

For, indeed, they are wonders. And to unaccustomed eyes, the eyes of visitors who had never known aught of the kind before, they would be simply amazing.

In either case, if we had not known, or if, knowing, we had not understood or cared to consider-the first step for us to take would be to look; to gaze hard, to find out what there is that is worth seeing and thinking about in the garden-world. This would not mean idleness. Real looking, real watching, real thinking, are often harder work than cutting or hammering or digging or studying. It is studying-trying to learn from the Book of Nature.

That great Book of Nature is more difficult to read than any printed volume; and naturally so. For the author of such a volume is a man, but the Author of the Book of Nature is God Himself.

It has easy pages, however, as well as hard ones; and it lies always within our reach. Anybody may read from it at any time. And that which we spell out for ourselves is worth far more to us than what we have been taught verbally by others.

\section{II-Many Prants}

This is what we have to do in our garden. We will try to make out a few sentences from the Book of Nature, lying invitingly open; and then we will go on to learn other facts, many of which we could not find out for ourselves. 
We all know that the trees around, excepting only the evergreens, have been lately as bare as the barest of those trees which still do not show any foliage.

Yet we may not have grasped the fact that each of those dead-looking branches is not only alive, but already is actively at work, putting forth a new array of spring clothing. If we did not know it, how should we guess that the tiny beginnings of leaves are now actually getting ready inside the buds of boughs and twigs, so as to come out into daylight at the earliest possible moment, dressing the whole tree in sweet fresh green, so giving it power to get through its summer work.

"What work?" you may ask.

At the outset you may be sure of one thing. Not only that each tree has some definite task to carry out, but that each leaf has its own particular share in that task. Roots, stems, flowers, one and all have their appointed service. Every part of a plant has its own especial work to do, for which it is especially fitted; and no other part of the plant can, generally, undertake that duty.

Wandering onward, we reach a wide border, crammed with flowers. The rich, brown earth is damp from rain in the past night. If we had never seen anything of the kind before-perhaps if we had-we might know little about the varieties of good food for plants, found in such soil, without which they could not grow. A long wriggling earth-worm half shows itself, and scurries away. Only an earth-worm, yet a most useful person; for he too, humble though he be, has his tasks.

Plants of many kinds are crowded together in the 
border. We note one that grows low, with small purple-blue blossoms, modestly trying to hide themselves among heart-shaped leaves, while betraying their presence by a sweet pervading scent. Close by are other tiny star-like blooms of bright blue, several on one stalk. Next comes a plant with crinkled leaves and rounded flowers of pale yellow, lifting their faces confidingly towards the sky.

These old friends we recognise at once-Violets, Forget-me-nots, Primroses. But how wonderful they would seem, if they dawned on our vision for the first time !

Along the outer edge of the border grow many double red and white Daisies; so unlike their cheery little pink-tipped sisters on the lawn, that a stranger would not call them by the same name. A patch of tall, earlyflowering Marguerite Daisies, standing hard by, really have a look of cousinship.

Tulips flourish in abundance; large red ones, single and double; little dainty yellow ones; and pure white ones with golden centres. The many-hued Polyanthus claims attention; and a silky Phlox with star-like pink blossoms; and a white-flowered Candytuft; not to speak of many more.

At the back grow bushes, laden with Lilac-blossoms, mauve and white; and a Laburnum flings its long golden tassels in the breeze; and on the hedge, behind the Lilacs, where a wild Rose grows luxuriantly, one green flower-bud has just begun to unfold itself, showing a tiny streak of coral-red.

All these we see for ourselves. And how much of them do we really understand? 


\section{III-What the Plants are doing}

Wandering still through the quiet garden, gazing at one plant after another, we come suddenly on the gardener, a hard-working man of the olden type. He is tying up some long trails of a creeper; and our presence seems to make no sort of difference to him. Presently we venture on a question-an attempt to draw him out. He surely knows much about these garden wonders. We try to intimate politely that he could tell us-things -if he would.

He goes steadily on with his work, not answering hastily. But after a pause, he says-

"Yes. I've seed a deal of their ways."

"Their ways!" That is rather a new idea. We had not perhaps thought of plants as having ways like human beings.

"What sort of ways?" we ask.

He takes a good while to consider. We begin to fancy that he has forgotten our question. But he straightens himself, looks full at us, and remarks-

"You just keep a look-out, and you'll see. They've got lots of ways-queer ways too, and no mistake."

"Tell us one-just one!" we beg; for he has taken up his basket, and is on the move.

"You can see 'em a-lookin' up at the sun, and follerin' him along!"

Then he disappears inside a small glass-house, and we exchange glances, deciding to take his advice.

That means careful study. Plant after plant, kind after kind, we examine. Many flowers, unmistakably, do not take any particular trouble to face the sun. 
Some turn carelessly another way. Some, like the Violet, prefer to creep into shade. Some hang their heads, either from modesty or from weakness of stalk. But gradually it dawns upon us how very many do really seem to face the sun, as if of set purpose.

Reaching again the large lawn, still with our heads full of this thought, we are impressed by the fact that Daisies are among the number of sun-lovers.

Hundreds of little white faces, with their golden centres, are uplifted straight towards that part of the sky where the King of Day shines in his brilliance. We examine them carefully, first from one side, then from another; and again and again we note how those hundreds of slender stems slope in one direction, like the bayonets of a regiment of soldiers, all in the same direction.

No; not all. This begins to perplex us. A few here and there fail to follow the rule. The idea occurs that possibly those few are in weak health, which would explain the fact.

Then again, several Daisy-plants are growing under the shade of a mass of bushes, so that direct sunshine is cut off. And since they are debarred from looking up at the sun, they wisely do the next best thing in their power, which is - to face towards the greatest amount of light. This they practise quite as markedly as the Daisies on the open space are facing the sun himself. The slope of their stems, therefore, is different from that of the other Daisy stems.

So much at least we have discovered for ourselves in one afternoon, But later in the day, going back 
to the same spot, we note something else, not less interesting.

In the afternoon the Daisies were all wide awake, gazing skyward. Now they have shut up their faces, folding the outer white rays over the golden centres, for all the world as if they were going to sleep.

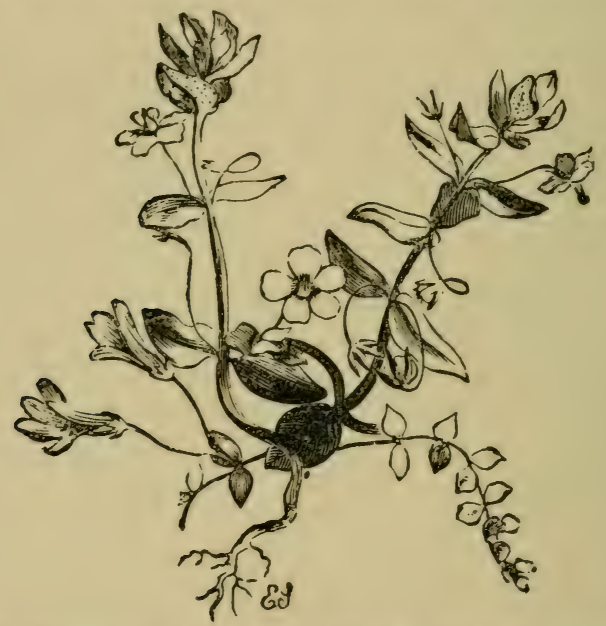

anagaldis arvensis (Scarlet Pimpernel) and a. tenella (Bog Pimpernel).

Another ramble round becomes necessary, to see if other plants behave in a like manner. We come across several which do. Tulips are plainly closing for the night; and a dainty little Linum has done the same. Also some tiny red Pimpernels, growing at the pathedge-only weeds, but not less pretty for that-and the bell-shaped Convolvulus follow their example.

Others might be noticed, not shutting up, but drooping 
on their stalks, with faces turned away from the darkening sky. But many remain open, and one or two are actually unclosing their flowers, which all day have been fast shut.

$$
\text { "Of all the floures in the mede, }
$$

Than love I most these floures white and rede,

Soch that men callen daisies in our toun." 1
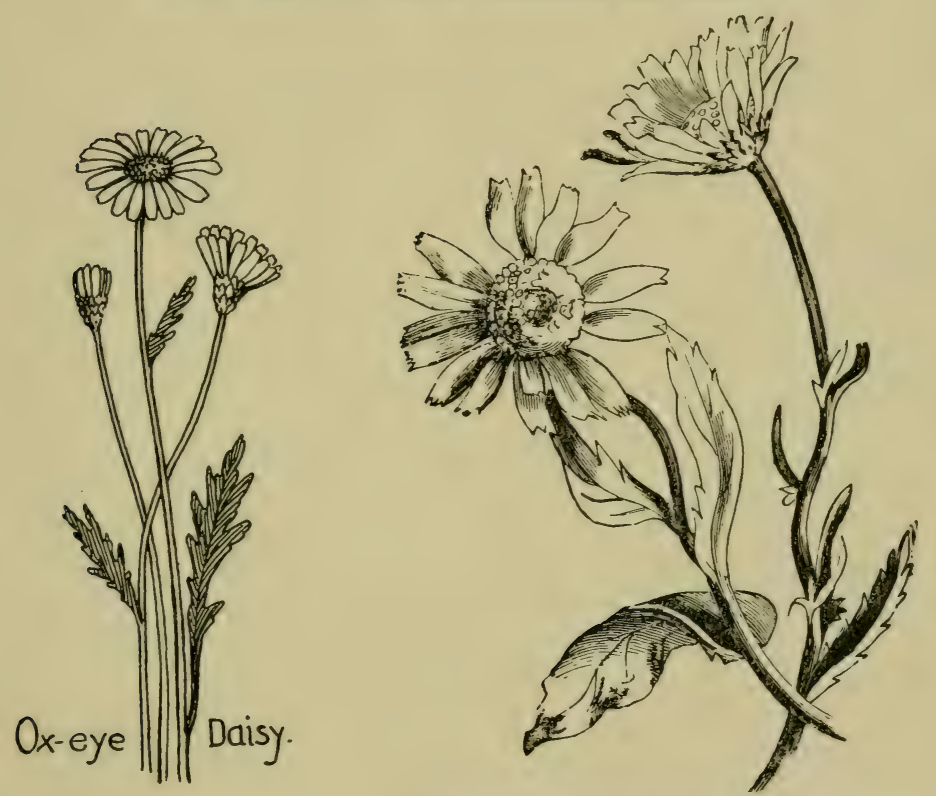

CHRYSANTHEMUM SEGETUM ( $Y$ ellow Ox-eye).

\section{IV-Growing Slowly}

As we go on, day after day, studying the garden, something else claims our attention.

1 Chaucer. 
Certain trees which were bare and brown now show a glint of green. Some which had boasted only a gentle flush of that tint, have small leaves. Others, which had displayed half-open leaves have abundance, fully open.

With lesser growths the same is seen. Plants which had carried only buds have now full blossoms. Some which had borne two or three flowers now bear many. The Rose-bud on the hedge is a bud yet, but its coral streak has so far widened that we feel any hour may see it in full bloom.

All this is only to be expected. But we begin to realise what it all means, and how wonderful are these silent changes, perpetually going on.

Why should we not watch the actual working out of such changes? Why not see with our eyes the growth of a leaf-the opening of a flower-bud? It happens incessantly, all around us. Flower after flower unfolds. Leaf after leaf expands. Can we not follow the wonder for ourselves, minute by minute, as it actually takes place?

We do our best. We sit down, and fix a steadfast gaze on the pretty Rose-bud, which seems just readymore than ready-to burst into bloom. We lookand look-and look-steadily, persistently, till eyes and brain are weary.

And it is in vain. Not the smallest movement can be observed. Not the faintest alteration can be detected. Tired of watching, we wander away, and in an hour or two come back-to find that the bud has opened; the Rose is in bloom.

Sometimes we have tried to see the movement of an hour-hand in a small watch; and we have failed. The 


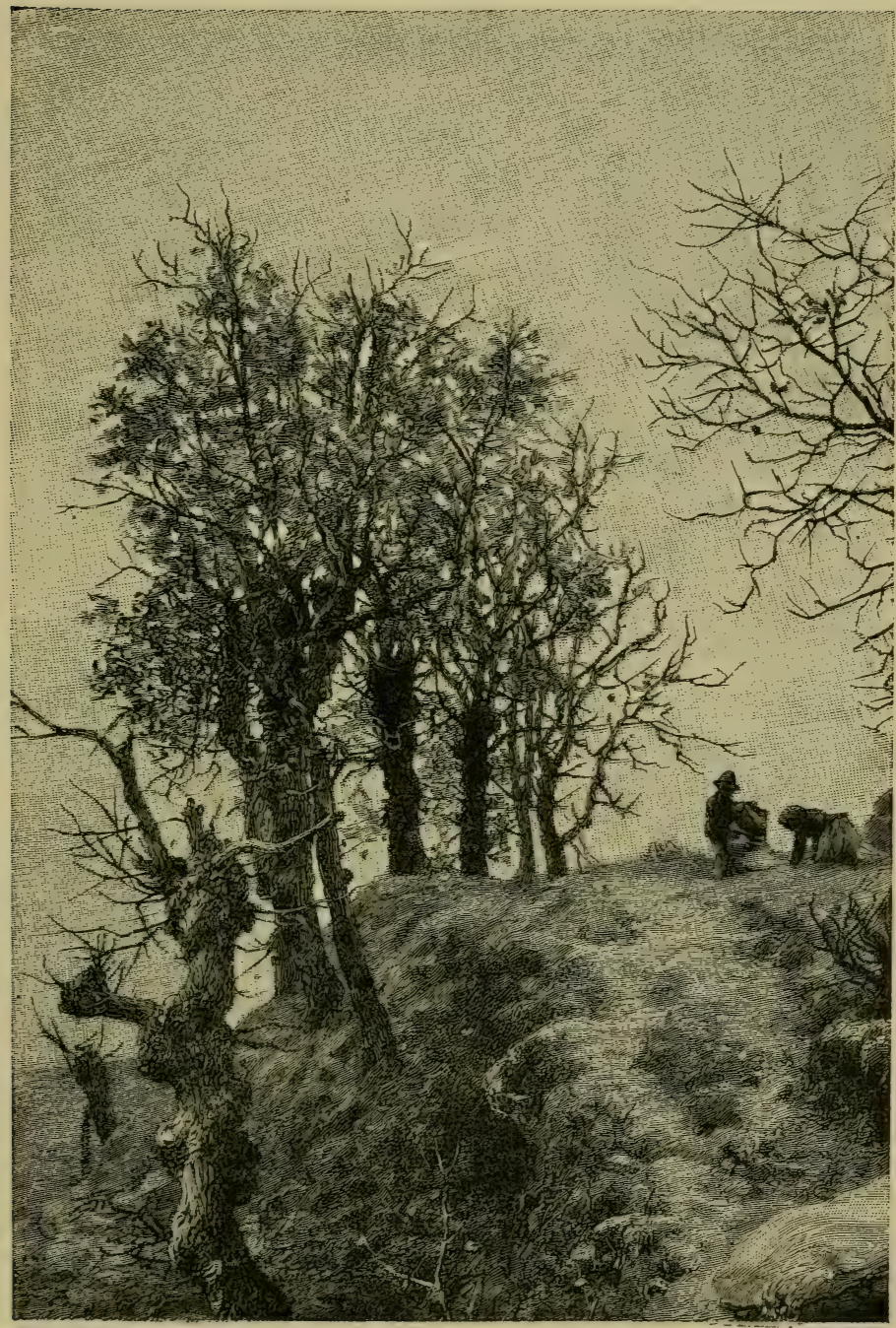

BREAKING INTO LEAF. 
hand does move, but so slowly, so gently, that we cannot detect its motion. So it is with plants and leaves and flowers.

In some cases growth is far more rapid than in others. A Scarlet-runner will in one night-if it is a good growing night, warm and close-become four or five inches longer. Hops are still more expeditious. A Hopshoot has been known in a single night to add eight or nine inches to its length. Yet even then, if we sat up with a lamp, and gazed continuously hour after hour, it is more than doubtful whether we should actually detect the growth.

As Keble wrote-

"Who ever saw the earliest Rose

First open her sweet breast?"

But it is worth while to make the attempt. Looking into such possibilities for ourselves is much more interesting than only to hear what other people may have done.

"A Rosebud by my early walk

Adown a corn-enclosèd bawk,

Sae gently bent its thorny stalk,

All on a dewy morning.

Ere twice the shades o' dawn are fled,

In a' its crimson glory spread,

And drooping rich the dewy head,

It scents the early morning.

So thou, sweet Rosebud, young and gay,

Shalt beauteous blaze upon the day,

And bless the parent's evening ray

That watched thy early morning." 1

7 Robert Burns, 


\section{PART II}

\section{THINGS GREEN AND FAIR}

\section{I-A Good Look Round}

Whether a garden be large or small, whether it is a town or a country garden, in any case it is sure to be full of interest.

Somebody once spoke of her little town-garden as "just the size of a pocket-handkerchief"; which was a modest way of stating the matter. But even the very tiniest scrap of a garden, if well cared-for and lovingly tended, may hold beautiful growths. And if you have no garden at all, there is still something to be done. You may have two or three plants in pots; or, better yet, a wooden window-box full of flowers. The commonest plants, the simplest blooms, are things of wonder and charm.

We all know something of plant-life. Like the visitors to a new garden, we do at least know that plants grow, and bring forth leaves and flowers; and that when the leaves die, fresh leaves come in their stead; and that, when seeds have been formed, new plants arise in time from some of those seeds.

But I wonder how many of us have begun to look on plants as living things-as not only having life, but having habits and ways of their own. I wonder how 
many of us quite realise that, as living things, they . breathe, they feed, they work; that they have what seem to be likings and dislikings; that each kind of plant needs a particular sort of place to grow in, and a certain amount of warmth; that some plants do well in one soil, while others must have a different soil; that the climate which suits one does not suit another.

All this and much more is true. Plants can be said to sleep and wake. Plants live out their lives, even as we live out our lives. Plants carry on their especial tasks. Plants may have good health or bad health. Plants, in fact, are beings-living creatures. They are a wonderful part of the vast creation of God. And they have a marvellous work to do for Him-and for us. Without plants, without the tasks that they carry out, we ourselves could not live.

We depend upon them for our daily food. For instance, for our vegetables-for cabbages and cauliflowers and potatoes; and for far more than these. And they are such good faithful little servants. They do not fail us. We shall hear more about this later.

Our World is made up of many lesser worlds, which interlace and yet are separate. The World of Mankind; the World of Animals; these we know. And also the World of Plant-life; the World of Green Things; the vast Vegetable Kingdom.

We cannot rightly speak of the whole Vegetable Kingdom as a world of green things, because it contains many growths which are not green; such as brown and red seaweeds; and yellow and grey fungi; and countless invisible specks of life. But in this book we have to do chiefly with green and flowering plants. 
"There was once a nest in a hollow;

Down in the mosses and knot-grass pressed,

Soft and warm and full to the brim-

Vetches leaned over it, purple and dim,

With Buttercup-buds to follow." 1

\section{II-Plants and Animals}

What is the real difference between Plants and Animals? That question comes first.

Why, of course - they are so very unlike. Animals can feel and suffer; animals can love and hate; animals can understand when they are spoken to; animals can-well, not exactly talk, but they can make us understand by signs and looks and sounds what they want. Sometimes we say of an especial pet, "That dear dog knows every word that is said to him."

But this is true only of a few among the highest and most sensible of animals. What we have now to think about is-all animals of every kind, from the highest to the lowest, as compared with all plants of every kind, from the highest to the lowest.

Your little dog may be clever and affectionate, and horses and elephants have extraordinary sense. But will an oyster understand if you speak to it? Can you win the love of a beetle? Is a cheese-mite intelligent? Could a worm do your bidding?

When we speak of a dog's powers, we are looking at the difference between higher and lower animals. What we have now to see is - the difference between any kind of animal and any kind of plant.

We can grasp in a moment the distinction between an Oak-tree and a horse; or between a Wellingtonia

1 Jean Ingelow. 
and an elephant. No one ever muddles up the one with the other. A man never stands gazing, and shaking a puzzled head, and saying: "Well, on the whole, I think the cow is an animal, and not a vegetable. I really believe that the Elm must be a plant, and not an animal."

But when we get very low down in the two Kingdoms, matters are by no means so easy.

When in the Animal Kingdom we leave behind us elephants and horses, cows and dogs, four-legged beasts of all sorts, birds, reptiles, fishes and insects. And when in the Vegetable Kingdom we leave behind us Oaks and Elms, Flowering Plants of all kinds, and Ferns and Mosses. And when we get right down to a wide borderland, just between the two Kingdoms, where the very lowest and smallest of animals and of plants are found-then perplexities begin.

For it is there that the line has to be drawn, dividing the Animal Kingdom from the Vegetable Kingdom. And that is just what is so hard to do. It becomes most difficult to say which of the minute creatures there is an animal, and which is a vegetable. Many mistakes have been made in the past.

Some tiny creatures, long believed to be animals, have turned out to be really very minute plants. And other tiny specks, long believed to be plants, have turned out to be really very minute animals.

You may think it odd that this puzzle should exist; since, after all, we are sure of one thing. Plants remain in one place, firmly rooted to the ground; while animals are not rooted, but move freely about. So that there is always one clear indication, by which to know them. 
Yes; if only the rule held good throughout. Strange to say, it does not.

In that hazy borderland, between the two Kingdoms, the test breaks down. Animals and plants, living there, are very tiny, very simple in make, very much alike, and very puzzling. Some of these minute animals will fix themselves in one spot, and stay there, and behave for all the world like plants. And some of these minute plants will actually swim about in search of food, going from one place to another, and behaving for all the world like animals.

So it is not surprising that learned men should have made a few mistakes, in trying to settle which was which; or that certain learned men do not believe that any clear line at all can be drawn between the two.

\section{III-The Parts of a Plant}

We will go now for a little stroll around the garden, and find out what there is to be seen. If you cannot go into a real garden, you must picture one in your mind.

The first thing to be noticed is this-that plants, in growing, follow a regular plan.

They do not come up anyhow, in a chance fashion, so that nobody can tell what to expect. Unlike as one plant is from another, still they are more or less built after one general scheme.

Certain parts are found in the greater number. And if one asks, "Which parts are those that go to make up a full plant?" the answer will perhaps be, "Oh, that is easy enough. There are roots and stems, branches and leaves, flowers and fruits and seeds, and heaps more." 
But we do not want to hear about "heaps." We want to have all the different parts of a plant brought under the smallest number of heads; under four heads. The four chief parts of a plant are-

\section{The Root; \\ The Stem; \\ The Leaves; \\ The Flowers.}

And under these four headings the whole plant is embraced.

First, as to the Root. This is not commonly pretty, though most useful and necessary. It burrows into the earth, branching out generally in divers directions. It does the work of an anchor, holding the plant firmly in its place, and keeping it from being blown away by gusts of wind. It drinks in water from the soil, to support the life of the plant, and to keep it in good health. Water and food, I might say. But all food taken by a plant has to be liquid, or else in the form of gas. Plants in general cannot, like men, eat anything solid.

Then secondly, the Stem. In smaller plants it is usually green. It acts as a backbone to the whole; or rather as a body, like the body of a man. It is the pathway by which all the water and liquid food, taken in by the roots, travel upward and pass into the branches, and thence into the leaves. In most cases the main stem sends out branches or lesser stems to right and left.

Thirdly, the Leaves. These are all-important. If you were to do away with the leaves, you would soon 
put an end to the life of the plant. Just as the roots drink in water and food from the soil, so the leaves drink in food from the air.

But they do not only drink it in. They also work up and alter that which they have received, together with that which the roots have sucked up; and they make it fit for food. Food, first, for the plant itself; and then food for animals and men. Leaves are the most wonderful little workshops, doing what nothing and nobody else in the wide world is able to do. Without the help of leaves, no plants could live or grow : and so no human beings could live or grow either.

Fourthly and lastly-the Flowers. These, too, are little workshops, different in kind. They are the seedgrowers.

You no doubt look upon flowers as by far the most important part of a plant, because of their beauty. But they have this other use, and a very weighty use. One chief work of a plant must always be to bring forth fruits and seeds, from which new plants may grow.

If no fruits, no seeds, were brought into being, it would soon mean an end of most of the vegetable-life on earth. In time we should have no more herbage, no more trees, no more grasses, no more corn or grain of any kind. All the old plants would die; and no new ones would come to take their place. The world would change into a vast rocky and sandy and pebbly desert, where neither animals nor men could live.

Yet, while this is the special work of flowers, and perhaps their most important work, we need not suppose 
it to be the only object of their existence. If it were, we might well wonder why they should be so lovely as they are, when little plain green blossoms could produce seeds just as well as beautiful and gorgeous ones. Many large trees have plain green flowers; and they carry on their task of seed-manufacturing most successfully.

True, a definite reason is known for the bright colours of flowers, as we shall find later. They are believed to act as a lure to insects, thus inducing them to do what is a very important piece of work in connection with the growth of plants.

But this does not cover the whole question. May we not confidently believe that, when Our Father in Heaven caused all these lovely forms and radiant colours to spring forth, He had a loving thought for us, and that He meant them to be a delight to His children who were to inhabit this Earth?

We know well the words spoken by Our Lord, Who Himself loved flowers, when $\mathrm{He}$ told His followers to "Consider the Lilies of the field, how they grow," adding that "Even Solomon in all his glory was not arrayed like one of these."

What an utterly different world ours would be, if no blue and crimson, no golden or pure white blossoms grew anywhere; no Roses, Pinks, Primroses; nothing but small insignificant seed-makers. We can hardly picture to ourselves such conditions.

Perhaps nothing speaks to us more plainly of the kindness of Our Father than the care He has taken to provide us with beautiful sights for our enjoyment. Just as nothing tells us more clearly of the love for beauty in the Divine Mind than do the flowers of earth 
in their endless and exquisite variety. Is not each one an embodied Thought of God?

"A thing of beauty is a joy for ever; Its loveliness increases; it will never

Pass into nothingness; but still will keep

A bower quiet for us, and a sleep

Full of sweet dreams, and health, and quiet breathing.

Therefore on every morrow are we wreathing

A flowery band to bind us to the Earth,

Spite of despondence. ...

$$
\text { Yes, in spite of all, }
$$

Some shape of beauty moves away the pall

From our dark spirits. Such the Sun, the Moon,

Trees old and young, sprouting a shady boon

For simple sheep; and such are daffodils

With the green world they live in; and clear rills

That for themselves a cooling covert make

'Gainst the hot season; the mid-forest brake,

Rich with a sprinkling of fair musk-rose blooms." 1

\section{IV-The Parts of a Flower}

Suppose we find our way to a Wild Rose-to that one which grew on the hedge in the garden which we visited in the first chapter of this book.

Those were spring days, and now it is summer. Or, if not, let us imagine that it is. We shall find that, instead of one bud only just opening, the tree carries a mass of delicate white pink-edged blossoms.

We will pluck one of them, and look at it carefully. What you have to think about is-not the Parts of a Plant, but the Parts of a Flower.

Notice first the small stalk on which it grows-an off-shoot from the main stalk or stem, coming up straight from the root. Then see where the flower meets its

1 Keats. 
stalk; and you will discover what look like five small pointed leaves, green in colour, joined at the bottom into one. This is the CaLyx, and the pointed leaflets are SEPALS.

Sometimes a calyx is all in one; sometimes the sepals are all separate; sometimes, as here, they seem to be half joined into one and half separate. It is this green part which covered up the bud safely before it began to open, and kept it warm and sheltered. The sepals

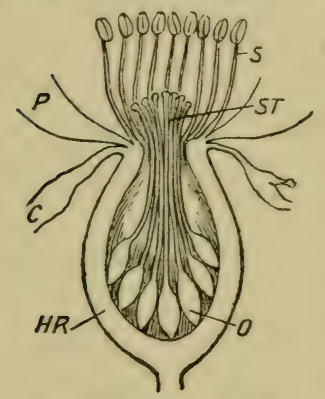

DIAGRAM OF ROSE FLOWER. really are leaves, though rather unlike the regular leaves of the Rose.

Within the green calyx we come to another circle of leaf-shaped things; not green, but white, with rosy tips; the prettiest part of the flower-its Petals. These, too, were folded protectingly over the inner part of the bud, before it opened; being themselves protected by the sepals.

In the Wild Rose there are usually five petals. All the petals of a flower, taken together, are known as the Corolla, or crown; and they, like the sepals, may be either joined into one, or half separate, or quite separate. They are, indeed, the crown of the flower, both in position and in beauty.

And the petals also of a flower are leaves; different in shape, different in colour, from the regular leaves and from the sepals, yet neither more nor less than leaves.

They are what we call modified leaves; that is altered 
leaves, changed leaves; altered in shape, changed in colour; but the same in actual origin.

Within the corolla we find a number of little dainty things, standing upright, slender, and with golden tips; golden, because of a fine yellow dust on them, which often comes off when touched. They are named Stamens; and the stamens again, though you would not think it, are leaves ; different once more in form and in tint, yet still leaves.
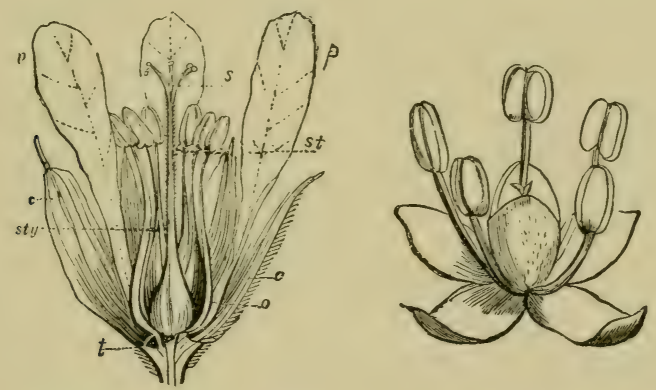

SECTION OF THE FLOWER OF HERB-ROBERT, A SPECIES OF GERANIUM : $c c$, calyx; $p p$, petals; st, andrœcium or stamens; $o$, gynœcium or pistil, composed of ovary $o$, style sty, and stigmas $s ; t$, thalamus. FLOWER OF GOOSEFOOT.

The golden dust is called Pollen; and no other kind of leaves, except stamens, has power to bring into being this wonderful yellow pollen.

Within the stamens, and surrounded by them as by a little bodyguard, are the tops of the Pistils. Some flowers have one pistil; some have two or three; some have many. The Rose has several. And the pistil, like the sepal, the petal, and the stamen, is just a modified or altered leaf. 
The pistils and the stamens together carry out the great task of Seed-growing. Stamens cannot do this alone. Pistils cannot do it alone. They have to work in company.

Perhaps you may find it hard to believe that those lovely pink and white petals, and those little soft yellow-tipped stamens, are not only one in nature with the green leaves, but also are one with each other.

This can be made more plain. The Wild Rose which

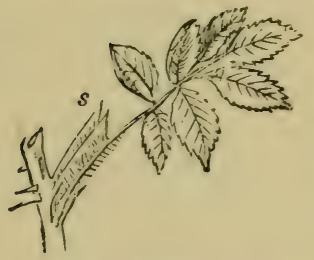

LEAF OF ROSE WITH STIPULES : 8 , apex of the sheath. we have examined is what we call " single." But now let us get two more Roses; not wild ones this time, but a half-double Rose, and another that is fully-double.

What do we mean by "single" and "double"?

Let us compare the three. The wild one has a single row of five petals, and a large array of stamens. The half-double one has a great many more petals, and not nearly so many stamens. The fully-double one has very many more petals still-it seems quite made up of petals-and no stamens. They have entirely vanished.

Where can they have gone? And how is it that so many more petals have appeared? Simply this-that the stamens have turned into petals. Curious, is it not? Both being in their nature leaves, they can be made by careful cultivation to change from the one form of leaf into the other. Stamen-leaves can become petalleaves; and petal-leaves can change again into stamenleaves. 
This does not mean that a single Rose-blossom can be so altered. It means that the plant which bears the one kind may be gradually made to bear the other kind. Any particular sort of Rose-tree can be so tended as to bring forth Roses more and more double year by year.

It is the gardener's care which causes such a remarkable transformation of stamens into petals. And if for a long while a Rose-tree bearing double Roses is neglected, and no further care is taken, then very often the Roses will become smaller and less double, with fewer petals and more stamens, each year. The plant has thus begun to revert, as it is called, to the old form.

Pistils also can undergo this change from their natural state into petals.

"In misty blue the lark is heard

Above the silent homes of men;

The bright-eyed thrush, the little wren,

The yellow-billed sweet-voiced blackbird,

Mid sallow blossoms blond as curd

Or silver oak-boughs, carolling

With happy throat from tree to tree,

Sing into light this morn of spring

That sang my dear love home to me.

Airs of the morning breathe about

Keen faint scents of the wild wood side

From thickets where primroses hide

Mid the brown leaves of winter's rout.

Chestnut and willow, beacon out

For joy of her, from far and nigh,

Your English green on English hills;

Above her head, song-quivering sky,

And at her feet, the daffodils." 1

${ }^{1}$ From England and Other Poems, by Laurence Binyon; published by Elkin Matthews. By permission. 


\section{PART III}

\section{A WIDE WORLD OF PLANT-LIFE}

\section{I-NAMES AND NATURES}

WE will think a little now about the immense numbers and varieties of Flowering Plants that are in the world.

Though the great mass of them are made, as we have scen, after one general plan-with Roots, Stems, Leaves, Flowers-yet there is every kind of difference between one and another.

Look around in any garden where you may happen to be, and see how many kinds may be discovered almost at a glance; how many different trees, how many different shrubs, how many different smaller plants, what quantities of little weeds. And if it is so in one garden, or in one place, what must it not be in the Earth as a whole?

We may, indeed, picture our Earth as a vast Garden, with rich beds and borders of flowers, with woods and forests, and with dry and sandy parts where few things can grow.

You might come across a man who has given his entire life to the study of plants; and you would find that he feels he has only begun to understand a very little of their extraordinary numbers and kinds, their ways of growing, their behaviour, their history. The 
more a man knows of Nature, so much the more he has learnt what an immense amount lies still beyond his power to understand.

And the true understanding of plants means a great deal more than just being able to give their names, either in English or in Latin.

It is useful to know their names, and still farther to be able to say to which Divisions or Families in botany each one belongs. But that is a small part of the question. Many people who can give names glibly enough know almost nothing of their real nature, their true history. And some others, who are not at all ready with their names, could tell you any amount about the plants themselves, and about their curious wonderful ways.

You know how, in the Animal Kingdom, we find an enormous variety of creatures, ranging from the eagle to the humming-bird, from the elephant to the mouse, from the whale to a speck of floating jelly.

And it is the same in the Vegetable Kingdom. There too, we have all kinds, all sizes. There too, we can range from the vast Wellingtonia and the wide-spreading Banyan, down to invisible vegetable-specks, living their own tiny lives; and from huge flowers, a yard across, down to blossoms so minute that they can only be seen with a magnifying-glass.

Not all plants are equal; not all have the same powers; not all are beautiful. And no two kinds of tree, no two kinds of herb, no two kinds of flower, are alike.

More than this, though one might not think it, no 

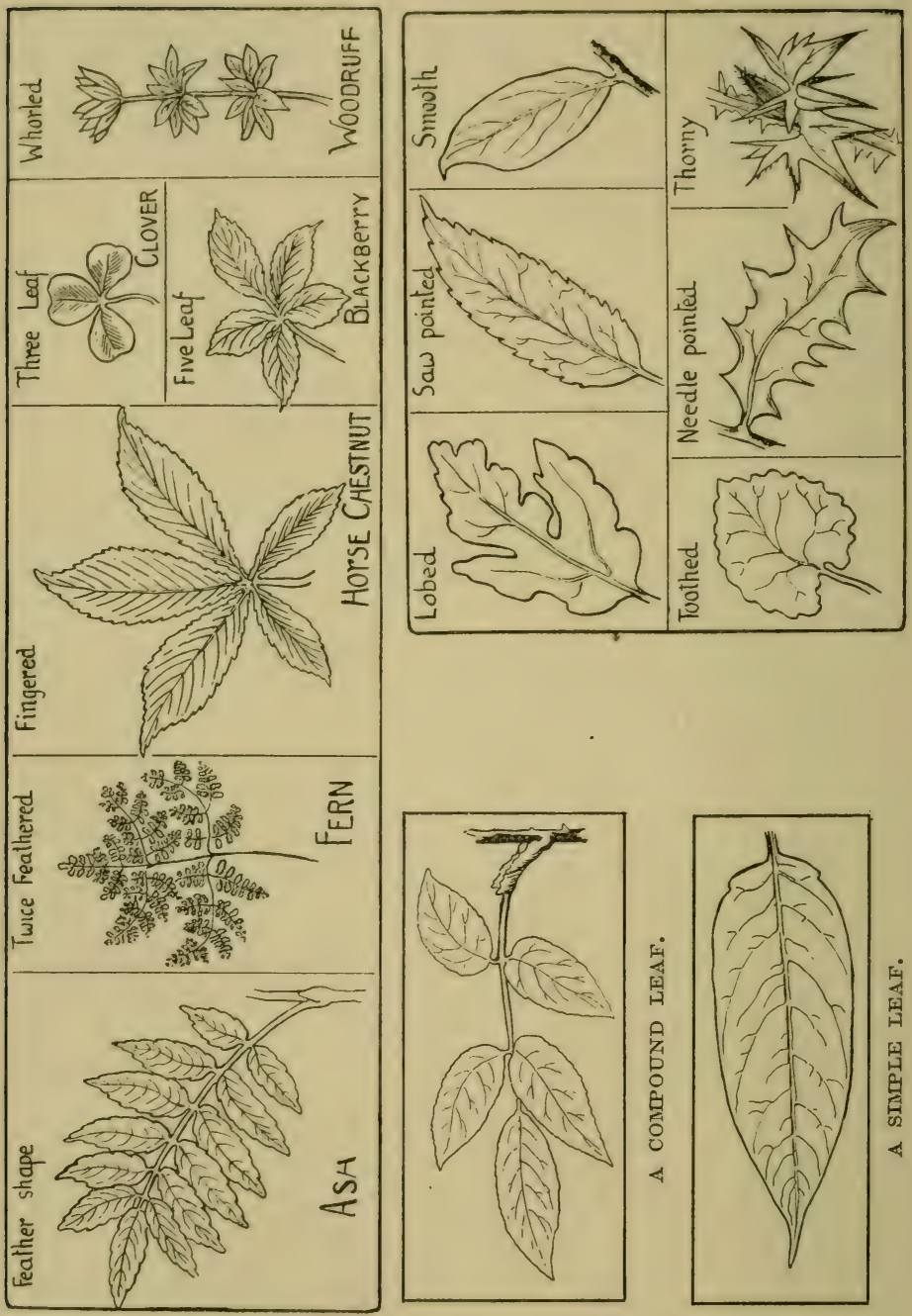
two flowers on one plant, no two leaves on one tree, no two blades of grass in one field, are absolutely the same.

Here, again, is something which anybody may prove for himself. Next time we go for a walk, or out into a garden, we might try to find two Oak-leaves, or two Elmleaves, or two Rose-leaves, or two Grass-blades, which are precisely the same; the same in size, in shape, in markings, without the very smallest difference.

It will not be an easy task. And when we think we have succeeded, we must put the question to the test by looking at both through a magnifying-glass, or under a microscope. If then we can still detect not the tiniest difference, we shall have done something to be proud of. But I hardly think we shall succeed.

All the leaves of an Elm will be alike; very much alike; just as the brothers and sisters in one family are sometimes very much alike. Yet generally each leaf will be slightly unlike all the other leaves, just as each child in a family is different from all the rest.

\section{II-Such Numbers !}

We have been thinking so far mainly of the higher kinds; those known as Flowering Plants; and we shall go on thinking mainly about them.

But before making any farther advance, it is as well to picture to ourselves, in some small degree, what is really meant by the whole Vegetable Kingdom; the vast World of Plant-life.

To do this we have to begin very low down, and to go steadily upward. We have to make a start far below 
the level of Flowering Plants. It will be like climbing a long ladder. Only, instead of a ladder standing by itself, we must picture in our minds a ladder surrounded on all sides by enormous numbers of vegetable growths. As we mount, step by step, we shall see one kind following another; beginning with the smaller and simpler sorts, and going on with those that are larger, less simple in make, more complex and finished.

At the very bottom we find ourselves in the midst of swarms upon swarms of those tiny vegetable-specks, spoken of earlier; specks so minute as to be invisible except under a microscope. Among them a great number of varieties are known; but in them all we find no trace of root or stem, of leaf or flower. In very many cases each one is a mere tiny cell of living jelly; and when they increase in numbers, it is done by the cell dividing into two-the halves going off in different directions as a couple of plantlets.

A whole book might be written about these specks of vegetable life alone; their number is so great. Only two or three kinds can be named here.

Sometimes on snow-clad mountains a curious sight is seen in the shape of a patch of red snow. That snow is not in itself red; for the colour is lent to it by multitudes of minute plantlets; millions and millions of them mixed with the snow; each one far too small to be seen by the naked eye. And even their red tint is borrowed from something else that is present; it is not actually their own.

You may have heard of the famous little Diatomplants-exceedingly small, but important because of their multitudinous numbers. Mere specks of life, 
they are so tiny that if a hundred of them were sprinkled on a piece of clear glass, and you were to hold up that glass against the light, you would see nothing. Yet the Diatoms would be there.

Real living water-plants are they; each one enclosed in a minute case or box, made of a flint-like substance, in two halves which exactly fit one another like a box and lid. The outside is decorated in all sorts of patterns; one kind having one pattern, and another kind another pattern. About two thousand different species are known; each particular species being marked with its own special design, unlike all the rest. The beauty and finish of these ornamental markings are marvellous. ${ }^{1}$

For thousands of years nobody knew anything about the Diatoms and their wonderful little boxes. It was not till men had learnt how to make microscopes that the Diatom-cases could be seen at all.

Somehow these living specks travel about; and probably it is by means of very fine lashes-called cilia-put out through little holes, and used like oars for rowing themselves along.

A step or two higher up the ladder brings us to the small and dainty Volvox plant, which may be found in many an English pond. It is greenish in colour, and globe-like in shape; and it too moves about like an animal, rowing itself along by means of little arms or cilia. It really is not one plant only, but a whole colony of plantlets, all pressed together and joined into one, and surrounded by a kind of envelope.

1 For illustrations of these Diatom-cases see The Romance of the Mighty Deep, by the same author: opposite pages 154,156 . 


\section{III-A LADDER OF LIFE}

Now as we climb we have to leave behind us these lowest and simplest forms of Vegetable life. Passing up two or three more rungs, we find ourselves soon among the company of Lichens.

Many a time, when looking at some old cottage or barn, we have noticed on the roof a curious yellow

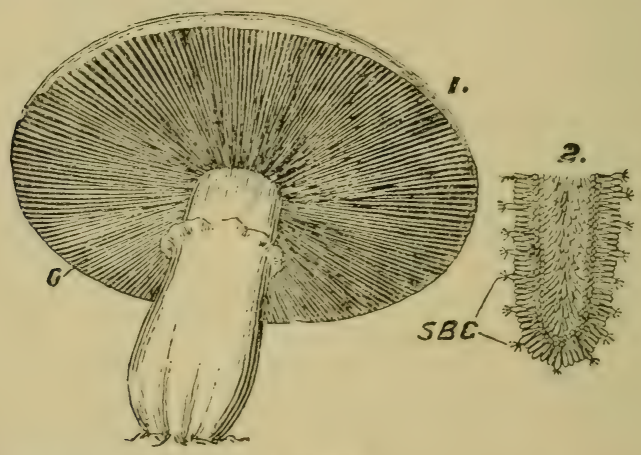

1. MUSHROOM, SHOWING " GILLS."

2. GILL PLATE IN SECTION, showing spore-bearing cells SBC.

colouring. Also on some aged wall we have seen a number of different tints, brown or grey or reddish, looking like stains. All these were due to Lichen-plants, and were actual vegetable-growths, flourishing where no other kinds could find sustenance.

Sometimes in a wood we light upon a piece of grey Lichen, looking much like a dried seaweed, and seeming as if it were dead. But it is not a seaweed, and it is not dead.

As we continue to mount the ladder, rung by rung, 


\section{A WIDE WORLD OF PLANT-LIFE}

we pass innumerable Fungus-growths-Mildew and Blight, Toadstools and Mushrooms-some of which are poisonous, and some have unpleasant smells. But all are in their nature vegetable.

Nor must we omit to note, in passing, the vast array of Seaweeds ; real plants these also. Most of us know well the prettylittle branching red ones; and the wide brown ribbons; and the slimy green kinds; but enormous numbers besides are found in other parts of the world.

All these-Lichens, Fungi, Seaweeds-belong to the great Lower Division of Flowerless Plants.

Soalso do the Mosses, farther up; and the huge brotherhood of Ferns, higher up still.

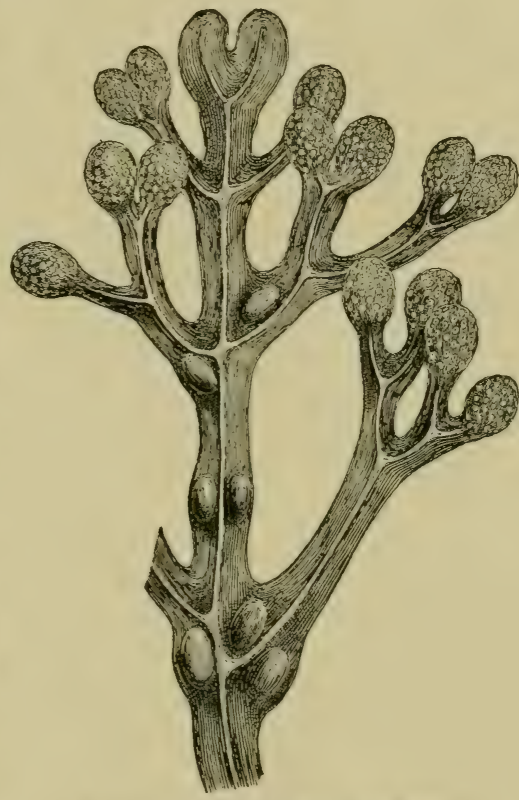

FROND OF COMMION SEAWEED (Fucus Vesiculosus.)

But when we get to the Mosses and Ferns, we see that we have made a very important advance. They come much closer to the Higher Division; for they have roots and stems and something very like leaves. Practically, the fronds take the place of leaves, and also they take the place of flowers. 
At certain times of the year we may sce on the back

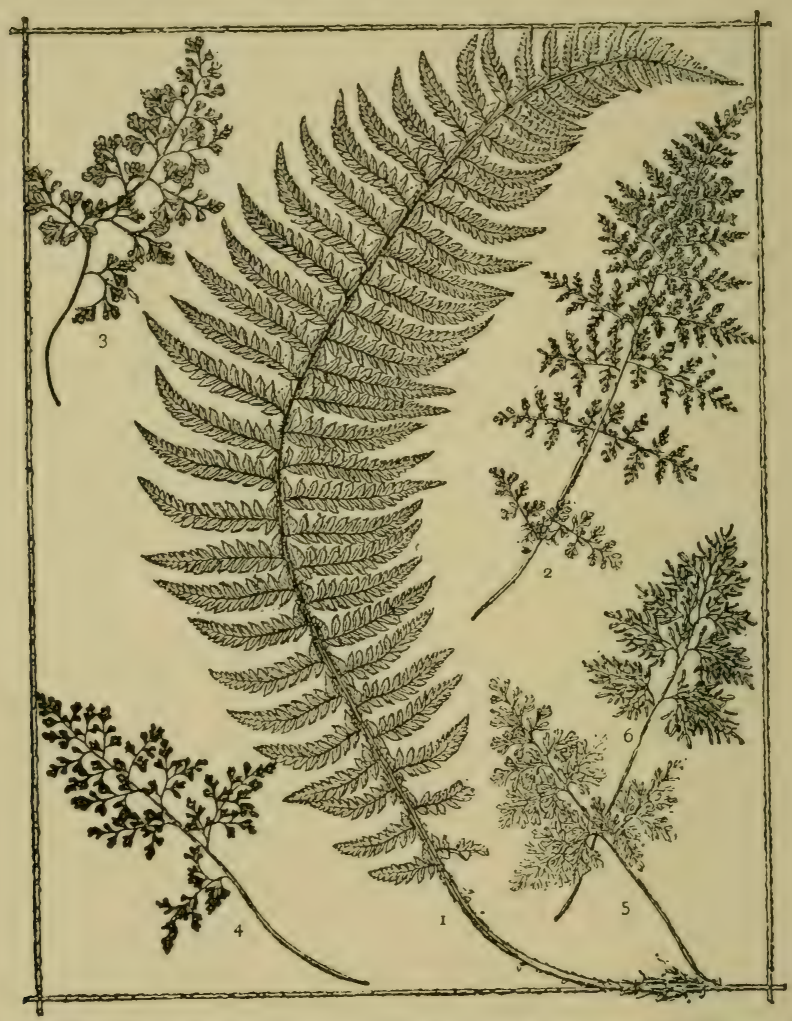

1. HARD PRICKLY SHIELD FERN (Polystichum aculeatum) (Upper Side). 2. ALPINE BLADDER FERN (Cystopteris regia) (Under Side). 3. ANNUAL MAIDENHAIR (Gymnogramma leptophylla) (Upper Side). 4. ANNUAL MAIDENHAIR (Gymnogramma leptophylla) (Under Side). 5. PARSLEY FERN (Allosorus crispus) (Barren Frond). 6. PARSLEY FERN (Allosorus crispus (Fertile Frond).

of a fern-frond curious raised brown markings, arranged in rows. This is known as the "fructification" of a 


\section{A WIDE WORLD OF PLANT-LIFE 35}

fern. In other words, it is the "spore-growing" part of the plant; and, like a flower producing seeds, it produces "spores."

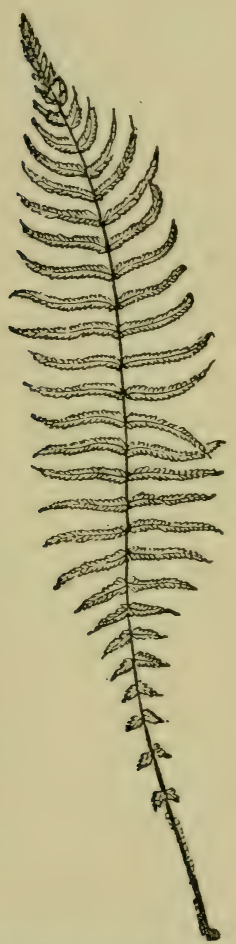

LEAVES OR FRONDS OF MOUNTAIN FERN.

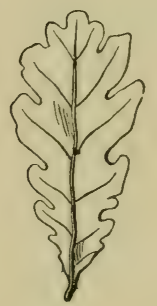

LEAF OF OAK.

These spores are very tiny, and are much more simple in make than seeds; but they serve the same purpose. Their task is the same. They have to provide, not only 
new ferns, but also new mosses, new fungi, new lichens, to take the place of the old when the old die. Thus the Earth is kept supplied with fresh generations of these various growths.

And now, as we still mount our ladder, we find a marked change, and we come to a new Division.

All the plants which we have so far noticed in our upward progress belong to the vast Lower Division of Flowerless Plants. But at last we have reached the great Upper Division of Flowering Plants.

At the very beginning of this Division we come across the large Grass Family, sometimes called the Grass Order. There are many such big Families or Orders or Tribes; and they include often such enormous numbers of distant cousins, that really they are more like Scotch "Clans" than Families.

Here we see the plan followed of a regular structure, built up out of Roots, Stems, Leaves and Flowers. Not always pretty flowers, or brightly coloured, but still flowers of some description, producing seeds.

All the Grasses belong to this Family; little low ones and tall rank ones. The highest kinds in Britain seldom rise above a man's waist; but in tropical countries they are often over his head. Wheat and Barley, Oats and Rye, Rice and Indian Corn and the Sugar Cane, are included in the same clan.

Presently we find ourselves in the midst of hordes of Flowering Plants, such as grow in meadows and hedgerows, on hills and downs, in valleys and by rivers, in gardens and parks; wild flowers and cultivated flowers; plants that we all know, and plants which none of us 


\section{A WIDE WORLD OF PLANT-LIFE}

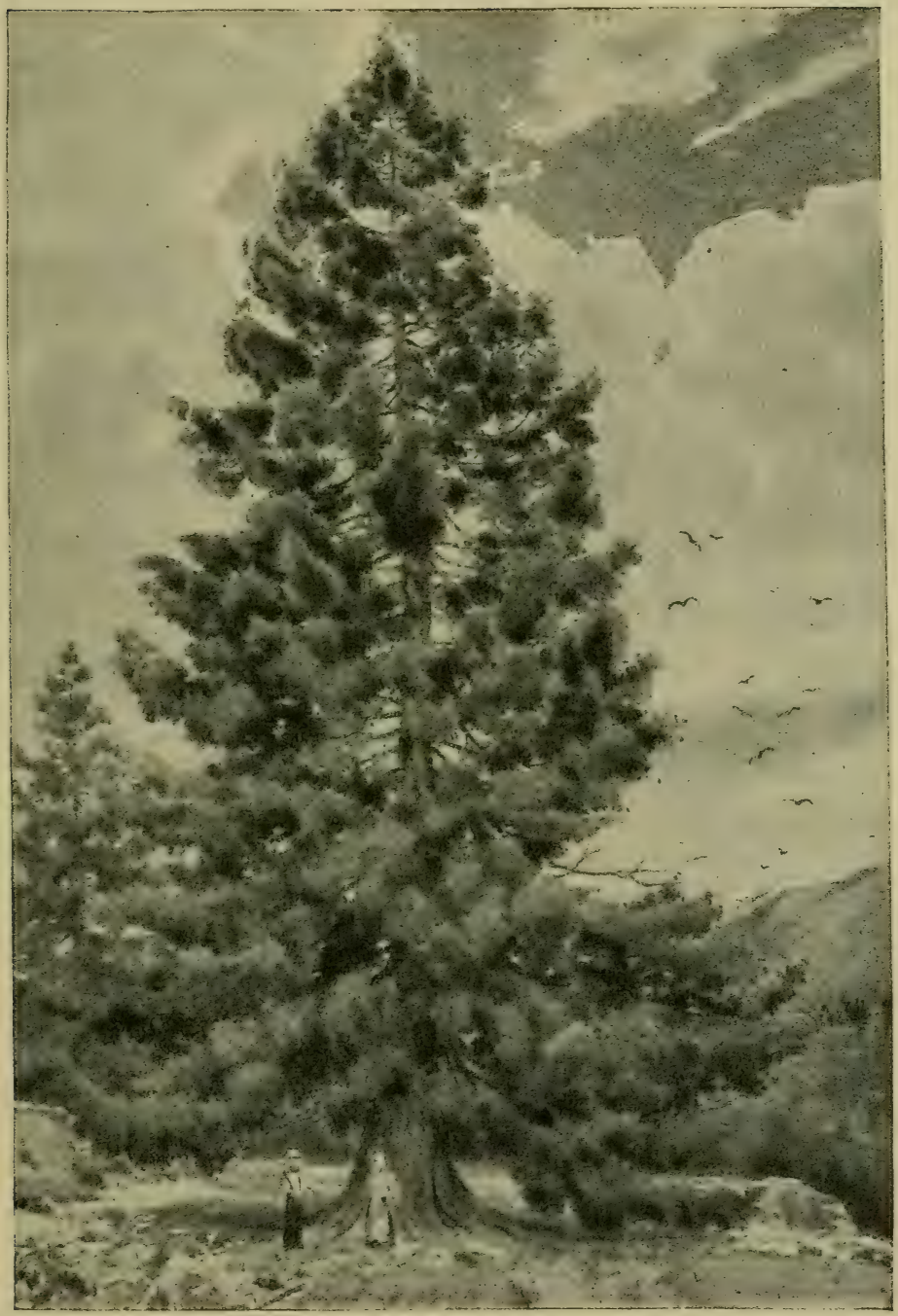

WELLINGTONIA. 
have ever seen; thousands and thousands of them; some beautiful; some curious; some sweet-smelling; some interesting. But, indeed, we may say that in one way or another all are interesting; and that very few are without some touch of beauty.

And the Trees; first the Pines and the Firs-conebearing-and the multitude of Palms. And then the immense varieties of Forest trees; not perhaps most of them really higher on the Ladder of Life than many flowering plants of a smaller growth. Yet they are so tall and stately that we might wrongly place them at the top. Can anything be more beautiful or more grand than an ancient Oak; or a great Beech, sweeping its branches to the ground; or a splendid Cedar of Lebanon; or a gigantic Wellingtonia with a trunk so huge that a dozen people might sit down to dinner within its bark; or a vast Indian Banyan-tree, with its numberless root-trunks?

Think of the extraordinary difference between one of these and a rolling invisible speck of jelly in a pond. Yet both are alive; both grow; both belong to the same Vegetable Kingdom.

" Large streams from little fountains flow, Tall Oaks from little acorns grow." 1

"I know a bank where the Wild Thyme blows, Where Oxlips and the nodding Violet grows; Quite over-canopied with luscious Woodbine, With sweet Musk-roses, and with Eglantine." 2

1 David Everett.

2 Midsummer Night's Dream. 


\section{IV-Some Curious Differences}

We have learnt now a little about two great Divisions in the world of Plant-life. Certain Subdivisions must also be mentioned.

With the very first beginnings of growth from a Seed sown in the ground or in a pot, we may notice that two humble small green leaflets creep quietly up above the soil. They are the Cotyledons or Seed-leaves; so-called because they are the first to spring from the seed. Each day they get a little taller; and soon other leaves grow up from between the two. In time the first pair, having done their share of work, fade quietly away; and the later leaves are often unlike them in shape.

Great numbers of plants begin life thus, with the two leaves. In some cases, however, as with the Oak and other Forest trees, we do not see them, for they remain underground, and the leaves which first appear are not true "Seed-leaves." Still, the fact is the same that most of our trees, such as the Oak, the Beech, the Elm, the Birch, the Sycamore, actually do begin their careers with a pair of such leaves. And thousands of lesser plants do the same.

A very unimportant matter, you may perhaps think. What does it matter?

Well, in one sense, perhaps not much. But a good deal that is interesting goes with it. .

Sometimes, in place of those two leaves a plant begins life with only one Seed-leaf; and that makes a considerable difference; or rather, a considerable difference goes with that arrangement. Plants which spring from bulbs may be said to have only one Seed-leaf. The 
Lily-of-the-Valley and the Narcissus grow thus; as also do Rushes and Grasses and Orchids.

If this distinction of either One or Two Seed-leaves stood alone, it might be of interest, though we could hardly count it to be worthy of much attention. But the number of Seed-leaves is not the only sign which marks off one big Subdivision of Flowering Plants from another.

It is a curious fact that most of the One Seed-leaf plants seem to grow-or, as one may say, to be built up-in threes. Their flowers, for instance, have usually three sepals and three petals, or else twice or three times three; that is, six or nine of each.

But the Two Seed-leaf plants are hardly ever thus. They are commonly found to be in fours and fivesor in twice four or five, as the case may be. ${ }^{1}$

Any of us may put this to the test. We may count the sepals and petals of a Lily and a Narcissus, and then those of a Buttercup and a Primrose. And usually these rules will be found true-that the Threes go with the single Seed-leaf, and the Fours or Fives with the double Seed-leaf. Once in a way a flower seems to have made a mistake, and to have its numbers wrong; but this is rare; and we have to examine several of a kind, noting what the greater number are like.

1 These lesser Divisions of Flowering Plants are known as Mono-cotyledons and Di-cotyledons; by which is meant Plants with One Seed-leaf, and Plants with Two Seed-leaves. There are also Plants which have several, called Poly-cotyledons, and Plants which have none, called A-cotyledons. "Mono" means One; "Di" means Two; "Poly" means Many; and "A" means "No." But we need not trouble our heads with the two last. 
A third distinction helps to mark these Subdivisions as apart each from the other.

With a Two-Cotyledon plant, if we study the leaf carefully, we shall nearly always find its markings-its ribs and veins - to be notted. There may be a main rib running up the middle, and there will be many lesser ribs or veins branching off sideways towards the edges. When we try to tear this leaf, it will not tear straight, but only in a jagged way along the branching side-ribs. This can be seen with an Oak-leaf or a leaf from a Rose-tree.

But if we get a Lily-of-the-Valley leaf we shall at once find that it is not netted or branched. A number of long lines run all the way from the stalk to the leaftip. And if we try to tear it, we shall see that it tears smoothly down its full length. It is the same with other Mono-cotyledon plants.

And yet again a fourth difference exists between these two big Subdivisions.

If an Oak or an Elm is cut down, and we look at the cut end, we may notice many lines running round, circle within circle. These lines show the age of the tree. Each year a fresh growth or layer takes place, between the outer wood and the bark; and so the trunk gets steadily larger year by year. That is the way in which Di-cotyledon plants grow (see page 74).

But the Mono-cotyledon plants increase in quite another fashion.

They do not grow by added outer layers. The wood of a Palm-tree, for instance, when cut down shows no circles, It does not increase by layer added to layer. 
Its wood grows in bundles of fibre, scattered through the trunk. Palms have slender smooth trunks, not rugged and massive like so many of our forest-trees. ${ }^{1}$

But if somebody asks why straight-veined leaves, stamens in threes or sixes, and inward-growing stems, should belong to the single Seed-leaf-and why branching-veined leaves, stamens in fours or fives, and outward-growing stems, should belong to the two Seed-leaves - no answer is possible. No sufficient reason has been found. We can only say that we do not know.

We do know, however, that whether they begin life with one cotyledon or with two cotyledons, it makes no difference as to the sweetness of the flowers, the beauty of the trees, or our enjoyment of them.

"Between the erect and solemn trees

I will go down upon my-knees;

I shall not find, this day

So meet a place to pray.

" Haply the beauty of this place

May work in me an answering grace,

The stillness of the air

Be echoed in my prayer.

"The worshipping trees arise and run,

With never a swerve, towards the sun;

So may my soul's desire

Turn to its central fire.

"With single aim they seek the light, And scarce a twig in all their height Breaks out, until the head

In glory is outspread.

1 These Divisions are often spoken of also as Exogens or outward-growing and ENDOGENS or inward-growing plants, 
"How strong each pillared trunk; the bark That covers them, how smooth; and hark,

The sweet and gentle voice

With which the leaves rejoice!

" May a like strength and sweetness fill Desire, and thought, and steadfast will, When I remember these Fair sacramental trees."

J. D. C. Pellow. 1

1 From Georgian Poetry, 1918-1919, published by "The Poetry Bookshelf." By permission. 


\section{PART IV}

\section{FAMILY RELATIONSHIPS}

\section{I-Put into Classes}

IN a small book of this kind it will not be needful to say very much about the way in which Plants have been sorted or classified by botanists. Still a few clear ideas on the subject, before going on to the make and the ways and the habits of plants, are desirable.

Plant-lovers recognised that certain groups more or less closely resembled one another; and it became convenient to have names for such groups, so that the nature of any particular one might be quickly conveyed to gardeners or botanists. If these groups could be arranged in some definite order, it would then be fairly easy for a gardener to make a methodical list of his stock, and for another to find any given plant in that list. He would look for it under the name of the group to which he knew it belonged. The question was-How to carry out such an arrangement?

Suppose we wished to classify Mankind into divisions. We might make one class of tall men, another of short men. Or one class of stout men, and another of thin men. Or we might sort them by the colour of their hair; those with black hair, those with brown, those with red, those with yellow. 
This would not be a good mode, because in other respects the men in one class would often be so utterly unlike. A far more sensible plan would be to sort them by their descent; by Race and Relationship. Many points of real resemblance-of inherited likenesswould then be found in large numbers of men, belonging to one family or to one race.

Several different methods were tried for plants, without much success. Then a learned Swede, named Linnæus, took the matter up.

His scheme ${ }^{1}$ was a very simple one. He placed all the Flowering kinds in Classes by means of their stamens and their pistils. First came ten classes : of plants with one stamen only in each flower, plants with two stamens, plants with three stamens, and so on up to ten stamens. Then a class with many stamens; and then some classes with stamens growing in particular ways. All these were again divided into lesser classes by means of their various kinds of pistils.

People were delighted with the plan; it was so easy to grasp; and it was taken up far and wide.

But in time botanists grew dissatisfied. The scheme was not good enough. It was too much like classifying men by their height and size, or by the colour of their hair. Such utterly diverse kinds came into one class, only because they happened to have the same number of stamens, when perhaps hardly another point of resemblance could be found in them.

Gradually that simple system fell out of general use, and another took its place.

This other is known as the Natural System; and in

7 Known as "The Linnæan System," 
it plants are arranged according to what seem to be their actual relationships. They appear to be related, because of their marked likeness one to another, not in one respect only, such as the number of their stamens, but in many respects; such as the way in which they grow, the forms of their leaves, the manner in which they produce seeds, and so on.
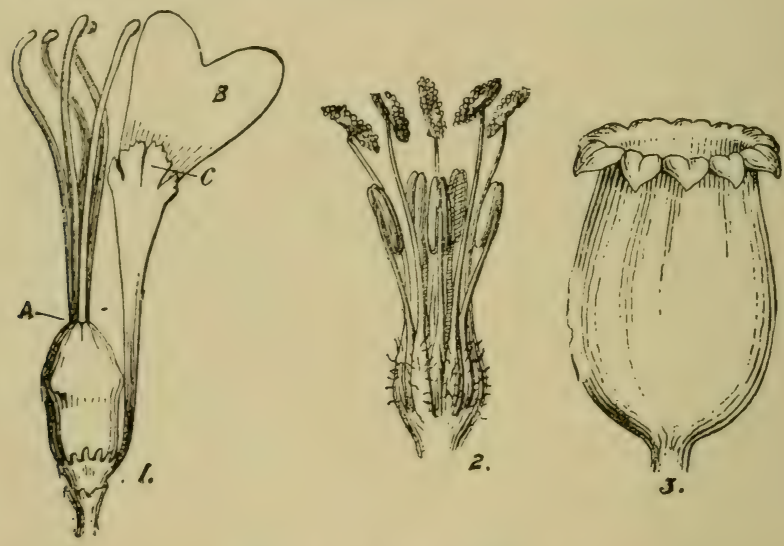

DETAILS OF RED CAMIPION.

1. Pistil and Styles. B. a petal to show attachment and Corona $C$.

2. Stamens. The anthers of the long ones have opened to shed the pollen.

3. Capsule.

By "relationship" we commonly mean descent from the same more or less recent ancestors. This we know to be true with men. And though we cannot absolutely declare that it is true with groups of plants, there is every reason to believe that it may be the real explanation.

It seems to be with them as with ourselves. Some 
people are very nearly related, such as brothers and sisters. Others, such as first-cousins, are not so near; and others, such as second and third cousins, are more distantly of kin. Many more, again, are united only by the tie of belonging to the same race, the same country; while countless numbers can only be called connected because they all belong to the great Family of Mankind in general.

We have already heard something of the first main division of all plants into two very large classesFlowerless Plants and Flowering Plants. Our business now is with Flowering Plants only; and chiefly with those which begin life with either one or two little Seed-leaves. These are separated into lesser classes, under various titles, as follows-

All Flowering Plants are divided into NaturaL Orders, sometimes called Families.

Each of these Natural Orders or Families is divided into groups called Genera. One such group is called a Genus.

Each Genus is divided, again, into different Species. This word is the same in the singular and in the plural. We speak of $a$ species and of many species.

Lastly, each species may be divided into many $V$ arieties; more or less alike, yet with differences.

The word "Tribes" is sometimes used as a title for a lesser division or class belonging to one of the Natural Orders. And, as stated above, the relationship here spoken of is believed to be a real thing; to come from actual descent. Plants which we look upon as near of kin are, in all probability, descended from one common ancestor. 


\section{THE GARDEN OF EARTH}

\section{II-Roses AND THEIR RELATIVES}

"Loveliest of lovely things are they

On earth that soonest pass away.

The Rose that lives its little hour

Is prized beyond the sculptured flower." 1

We have noticed earlier the make of a Wild Rose. It was white, with pink tips; and it had five green sepals, partly joined into one, and five tinted petals; and many delicate gold-tipped stamens.

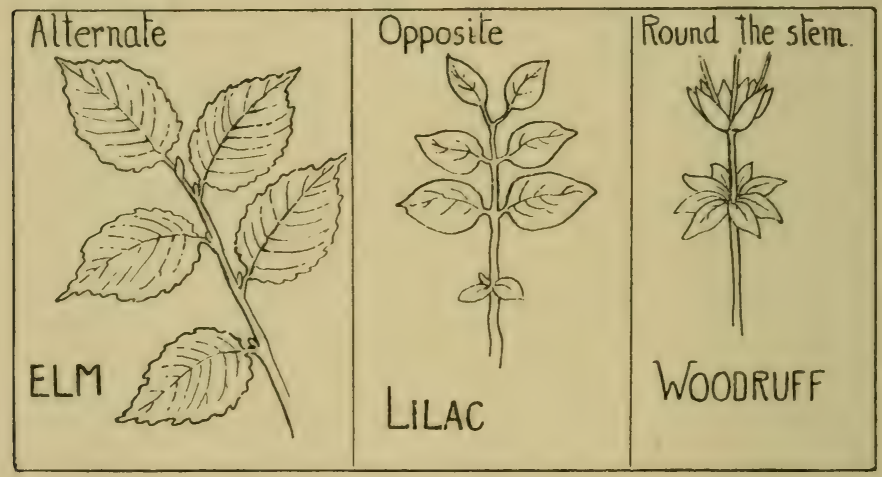

We might have seen that the leaves of the plant grow alternately; not in pairs, just opposite, but first one on one side, then another higher up on the other side. Also we might have noted the tiny leaflets, called Stipules, growing at the bottom of each leaf-stalk.

Now we will look at a very near relative of the Rose; a first-cousin. This is the Strawberry Plant. If we examine the flower, we shall find not indeed only five, 1 W. C. Bryant. 
but twice-five sepals and five white petals, and a great many stamens; also stipules, but not alternate leaves.

Another near relative we might find, if it is the right time of the year, in the hedge-rows. Its name is Potentilla or Cinquefoils; and it has a pretty little pale yellow flower, with again ten sepals and five petals and many stamens. One kind has soft white undersides to its leaves.

These all belong to a great Order or Family, named RosAcEe; and that Order is divided into three Subfamilies: the Rose Sub-family; the Pear Sub-family; and the Almond Sub-family. Sometimes the whole large Order is spoken of as the Rose Famiry. But while each of the Sub-families really is rather like a very big Family of innumerable cousins, the whole Order is more like a huge Tribe or Scotch Clan.

And think what a useful Tribe this is to us. What should we do without the Strawberries, the Raspberries, the Blackberries, the Cherries, the Apples, the Pears, the Almonds, the Plums, the Peaches, and many other fruits, which its different members manufacture for our use?

Or, again, what should we do without the multitudes of lovely Roses, and of numberless other beautiful flowers, belonging to it?

We have already seen some of the general signs by which we may recognise many members of this very fascinating clan. One other characteristic must be mentioned : that, with hardly an exception, its members do not manufacture anything hurtful or poisonous to man. 
The question of their seeds is interesting, because from them come many of our favourite fruits. And though they are so nearly related, they differ oddly in the manner in which those fruits grow and ripen.

For instance, with the Strawberry flower. Within its clustering stamens are several pistils, each of which

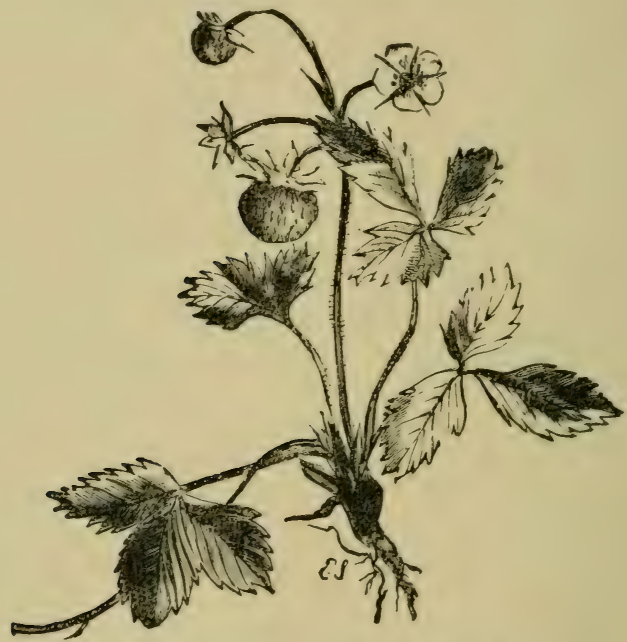

FRAGARIA VESCA (Wood Strawberry).

has its own stigma, its own style, its own ovary, the last-named holding one tiny beginning of a seed.

As time goes on, the petals having done their work fade and drop off, and the sepals close in around the young fruit. This fruit really is the receptacle of the flower; a sort of tiny cushion, from which the pistils grew. It begins to swell, and gets gradually larger and larger. Later on it also gets rosier and rosier. 
Meanwhile, those parts of the pistil which contain each one its little seed get harder, but not bigger. And as the berry increases in size they slowly separate, going farther and farther apart, till at last they are scattered all over the crimson surface, as you will see in any ripe strawberry. Those small, yellow, seed-like things are really dried-up pistil-remains, each having its own seed inside.

The Raspberry follows quite another plan. Here we find not ten, but five sepals, and also five petals. And here again-as with many flowering plants-there is the receptacle from which the pistils grow. But in this case it is not the receptacle which swells into a luscious fruit.

If you look closely at a ripe Raspberry you will see, rising from its rather lumpy surface, a number of tiny threads. They are the remains of the pistil-styles; and so the ripe parts of the Raspberry are actually the pistils, which have changed into this soft state, pressed closely together. And the hard part within, from which you pull the ripe berry, is the dried-up remains of the receptacle, which has given up all its juices to feed the growing fruit.

With Apples and Pears we have again a different structure. In their flowers also are found the five calyx-divisions, and the five petals, and the many stamens. When an apple is fully ripe, you see at the end farthest from the stalk a dried-up something, which is just the remainder of part of the sepals. But part of those same sepals has united with the pistil, to grow into a beautiful and refreshing fruit, in the E 
middle of which-if you cut it open carefully-you may find five divisions, and one or two seeds hidden snugly in each.

Then, again, there is the mode followed by stonefruit trees, belonging to this Family : such as Plums and Peaches, Apricots and Cherries. These also have their five sepals, their five petals, and their many stamens. But with them we find only one pistil, which grows and changes into a soft eatable fruit, containing inside a single seed, shut firmly up within a hard protecting stone.

Countless lesser differences run through the numberless varieties of this great Order, to which we owe so much. We have gone more fully into the "ways" of the Rose Tribe than will be possible with others. But it is well to gain a clear notion of what is generally meant by such an Order or Family, and by its Subfamilies and relationships.

It might make us think of the Tribes of NorthAmerican Indians, which in olden days used to wander over the country; each separate Tribe being divided into Families, the members of which were closely related, while the whole Tribe was connected, but more distantly.

"Ye Violets that first appear,

By your pure purple mantles known, Like the proud virgins of the year,

As if the spring were all your own-

What are ye when the Rose is blown?"1

"What does it take to make a Rose, Mother-mine?

The God that died to make it knows;

It takes the world's eternal wars,

${ }^{1}$ Sir Henry Wotton (A.D. 1600). 
It takes the moon and all the stars,

It takes the might of heaven and hell, And the everlasting love as well,

Little child." 1

\section{III-"ButTercups AND DAISIES"}

Next we have to think about two or three more such Orders or Families in the Kingdom of Plant-life.

Suppose we begin with a Buttercup. If it is spring or early summer, and if a field happens to lie near, we may easily find one. In examining flowers a small magnifying-glass is very helpful, though much can be done without it.

About half-way down the flower-stalk one or two little leaves will be found, not unlike the other leaves, only not so large, and these are called Bracts. Many plants have no bracts.

We shall see once more five small green sepals, and five bright yellow petals, and many stamens; and in the centre, growing up from a little cushion-like receptacle, several pistils. In these points a Buttercup is much like the flowers of the Rose Order. But there are differences.

The stamens of the Buttercup-and of many other plants belonging to the same Order-grow from close below the ovary, instead of, as with many of the Rose Family, from around or above it. This may seem to be a very slight matter, yet with it appears to go a distinction which is far from slight.

The plants belonging to the Rose Tribe manufacture

1 This and other quotations from Mr. Alfred Noyes in this volume are from his Collected Poems, published by William Blackwood, and are used by permission. 
with hardly an exception only food that is good and wholesome. But plants belonging to the Buttercup Order have, in many cases, fruit that is very unwholesome and even poisonous; and in their stems are sometimes found acrid and burning juices.

We do not in the least know why wholesome fruit
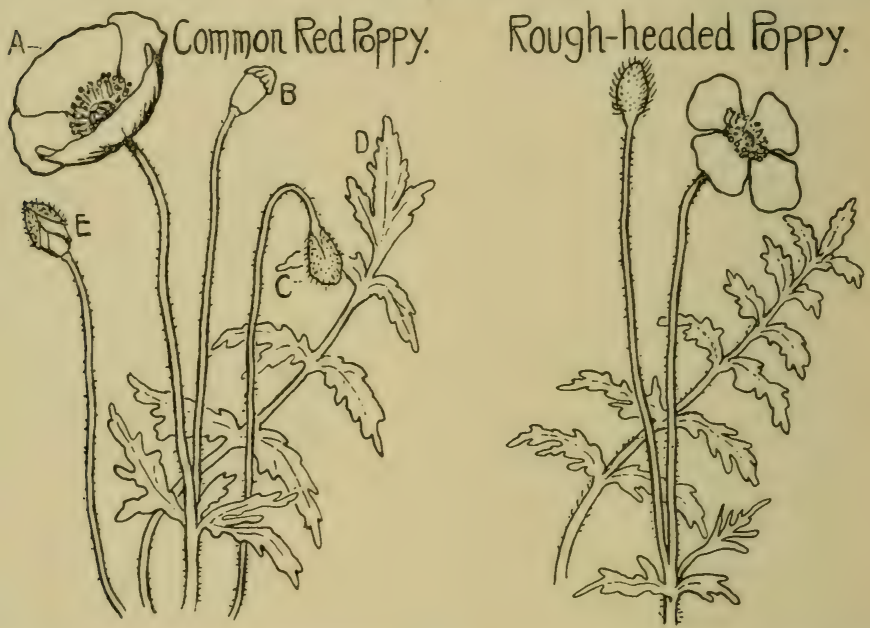

should go with stamens that spring from above the ovary, and unwholesome fruit with stamens that spring from below the ovary. We only know that so it is. Many travellers with some knowledge of botany, when going through a wild and strange country, have trusted to such tokens as a means of telling safe from unsafe fruit, and have found the plan to answer.

The Buttercup Order, often spoken of as "The Crowfoot Family," 1 contains many flowers familiar

1 Order, Ranunculace 
to us all, such as the Anemone, the Hepatica, the Larkspur.

In some respects the Poppy Order or Family, ${ }^{1}$ comes rather near to it. Many of the plants in this Order also manufacture fruits unwholesome and even hurtful in kind. From the Poppy itself comes that stupefying and deadening Opium, which works such terrible harm in Eastern countries.

A Poppy flower has many stamens, but only two sepals and four petals. Its pistils are joined together, and do not grow separately, as with a Buttercup. Its juice is often milky in character.

Now let us turn to one of our oldest and commonest and dearest little friends, the Daisy, beginning with what a poet of to-day has said about it-

"I know why the Daisy is white, my dear, I know why the skies are blue;

I know that the world is a dream, my dear, and I know that the dream is true;

I know why the Rose and the Toadstool grow, as a curse and a crimson boon-

Hey! diddle, diddle, the cat and the fiddle, the cow jumped over the Moon." 2

With which unexpected ending we will take a Daisy in hand and examine it.

The golden centre is there, which we often call the Daisy's "eye," because with it the flower seems to gaze so cheerfully upward. And around this golden centre-which you might take for a mass of stamensare pure white rays, or white rays tipped with crimson,

1 Order, Papaveracee.

2 Alfred Noyes. 
standing out in a circle, and you might suppose them to be the petals of a single flower.

But the golden centre is not made of stamens, and the outer rays are not ordinary flower-petals. We talk of the Daisy as "a flower," yet really it is not one flower only. It is a whole bunch or collection of tiny flowers or "florets," as such minute blossoms are called. And only in a sense can we speak of the whole as one flower.

Those tiny, yellow, stamen-like things in the centre

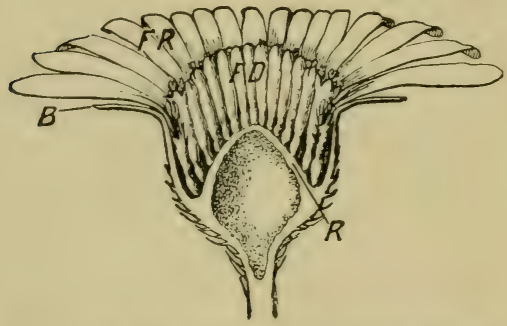

SECTION OF FLOWER HEAD OF DAISY. are florets; each having its own corolla and stamens and pistil. And the white rays surrounding are florets also, different in shape, yet each again having its own corolla and stamens and pistil. Altogether there are between two and three hundred of them in a single Daisy.

The florets have no green sepals of their own, however. Instead of this, there are little, green, sepal-like leaves surrounding the entire collection of yellow and white florets. These we might call the "calyx," though the right word for them is Involucre - a word something like envelope. They really do "envelop" or cover up the young Daisy bud.

A Daisy is a Composite Flower, for it is composed or made up of many florets, all growing together and behaving like a single flower. It belongs to the "Com- 
posite Order," 1 sometimes spoken of as the "Sunflower Family."

We all know the big Sunflower, with its soft central cushion of yellow florets, and the large outstanding yellow rays. This is an important member of the Family; and, indeed, a great Sunflower looks as if he had an extremely good opinion of himself.

Then we have Dandelions, and Thistles, and Chrysanthemums, and China Asters, and many more; though it must not be taken for granted that every plant with " composite flowers" belongs to the same Tribe. Other marks beside those already named distinguish its members. But we have not space to go farther into the matter here; though I think we may spare room to quote what our northern poet of past days had to say about a Daisy-plant, which stern duty forced him to demolish.

"Wee, modest, crimson-tippèd flower,

Thou's met me in an evil hour;

For I maun crush amang the stoure

Thy slender stem;

To spare thee now is past my power,

Thou bonny gem.

"Cauld blew the bitter biting north

Upon thy early, humble birth;

Yet cheerfully thou glinted forth

Amid the storm;

Scarce reared above the parent earth

Thy tender form.

"The flaunting flowers our gardens yield,

High shelt'ring woods and wa's maun shield,

But thou, beneath the random bield ${ }^{2}$

O' clod or stane,

Adorns the histie ${ }^{3}$ stibble-field,

Unseen, alane.

1 Order, Composite.

2 Shelter.

3 Dry. 
"There in thy scanty mantle clad,

Thy snawy bosom sunward spread,

Thou lifts thy unassuming head

In humble guise;

But now the share uptears thy bed, And low thou lies!" 1

Another plant, neither pretty nor sweet but very common, may have a moment's attention, the Wild Parsley. It grows in fields and waste grounds, and a second name for it is "Fools' Parsley." It looks so like real Parsley that children have sometimes eaten and have been made ill by it or even poisoned.

The manner in which this plant grows should be noticed. Several flower-stalks branch outward from one centre, and often lesser stalks branch outward again from these. In each case the stalks, springing from one spot and bearing tiny white flowers at their tips, stand out somewhat in the fashion of an open umbrella held upside down. So the Order to which the Wild Parsley belongs is described as "Umbel-bearing." 2 The flowers are said to "grow in umbels," like an umbrella.

To the same Family belong the Carrot, the Parsnip, and Celery, also Hemlock, which is poisonous. It is curious that Celery which when cultivated we find so good to eat, is unwholesome when in a wild state.

Certain plants, branching out much after the same fashion, such as the Elder-bush and certain Geraniums, do not belong to this Order.

These few examples will be enough to give some little idea of what is meant by Orders and Families,

1 Robert Burns

2 Order, Umbelifierex. 
and also of the way in which plants are grouped in Classes.

But the subject is such an enormous one that it has

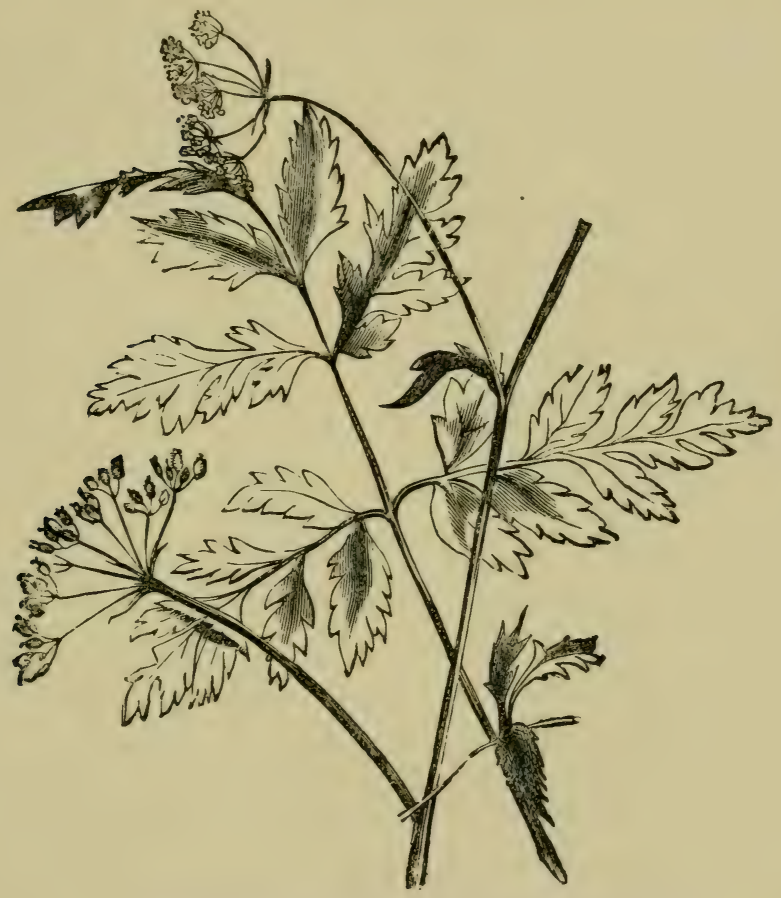

CaUCAuIs anthriscus (Upright Hedge-Parsley).

to be studied by itself. There are numberless books, large and small, written about the Divisions and Classes.

It is a good plan to hunt out the various flowers 
which may be found in one's neighbourhood; and then, with the help of a book about wild flowers, to learn all that one can about them. Not only their names, but the principal marks by which they may be known again, and by which some of their near relatives can be recognised. All this, as one goes on, becomes exceedingly interesting.

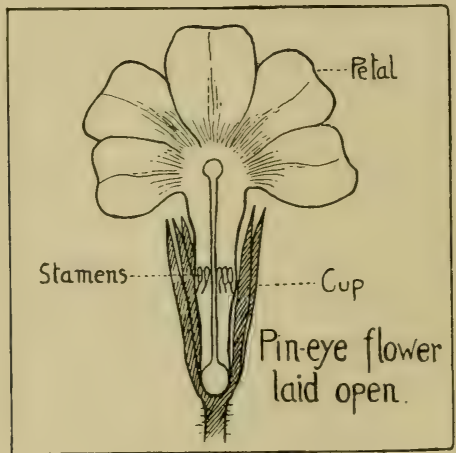




\section{PART V}

THE WORK OF ROOTS AND STEMS

\section{I-WHAT SOIL IS MADE OF}

WE all know from early childhood that plants grow out of the earth, for it is a fact constantly before our eyes. But not everybody thinks seriously about what he sees, and not everybody considers and wonders how a plant thus comes; what is in the ground to make it grow; why it should appear ; and why, having appeared, it should continue to gain in size and height.

People are so used to these marvels, so used to having small plantlets push their way up through the soil, and bring forth leaves and flowers and fruits, that they take it all as a matter of course and forget to feel any surprise.

Yet it is by no means a matter of course !

Why should plants come up? And why should they increase in size? And why should they bear leaves and flowers, and produce fruits? If we did not know that things are so, we should never have expected such extraordinary happenings. For though they seem to us quite ordinary, they would not be so to one who had never before seen anything of the kind.

What can there be in the soil which does so much? 61 
It does not do all, for air and rain and sunshine all share in the work, but it does a great deal.

You have noticed often the different kinds of soil found in different places. Here it is yellow and sandy; there it is white and chalky. Here it is red; there it is grey. Here it is coarse and stony; there it is fine and

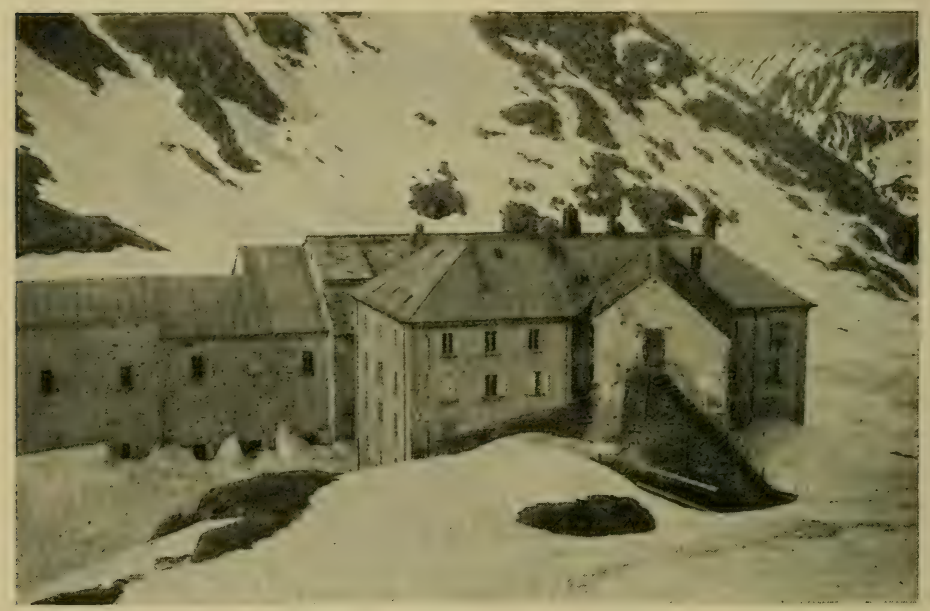

GRAND ST. BERNARD IN WINTER.

soft. And if we go to the top of a high mountain we come upon great spaces of solid rock, with no soil at all worth mentioning.

At the Grand St. Bernard for instance, in Switzerland, where the monks live and go out with their big dogs to hunt for travellers lost in the snow, it is all hard granite rock with no covering of earth. Nobody can dig there, for you cannot dig rock. 
Earth's soils are largely made from rocks. The hard rock has first to be split and broken and crumbled, and then gradually mixed with other materials; and at length soil is formed, in which plants can grow.

More powers than one go to this work of soil-making. It is tremendously important work, and it takes a good deal of time.

First King Frost steps in. He splits the rocks, and breaks up the stiff earth-clods, and does no end of good. Where a little water happens to lie in a crack, it presses the sides of the crack as it freezes farther apart, and so begins to demolish the mass. Bitterly cold weather, though unpleasant, is much needed each year for the soil.

Frost acts quickly and strongly; but another power, which is gentle and slow in its methods, does as much if not more in its own way. This is-Rain. One would hardly suppose that small falling raindrops could help to destroy solid rocks; to "decompose" them is the right word, and to "decompose" simply means to "unmake."

That which gives raindrops this power is the presence of certain gases, such as nitric and carbonic acid gases, in the water. If enough of these is present it can eat its way gradually through the hardest rocks. At the same time, such gases unite with other substances found there, to form salts which are required for the growth of plants.

When the soil is so far ready that certain of the simpler kinds, such as lichens and mosses, can begin to grow in it, and when spores have been brought by wind or water or animals, then such plants themselves will 
soon lend help. Their roots creep down quietly into the cracks and force the sides more widely apart, and as they die and decay they become part of the soil, fitting it for use.

Then as the soil goes on improving, and plants of a higher make can thrive there, these also shed their leaves and the leaves decay, and by and by the plants die also. All this enriches the earth more and more.

Soil that is formed only or chiefly of broken and crumbled rock may be spoken of simply as " earth" or " earth-mould," but when a large amount of leaves and dead plants have been added it becomes "vegetablemould." It is then of far greater value.

Many different kinds of food required by plantssuch as potash, soda, magnesia, lime-are found in soils ; and each particular kind of plant must have its own especial kinds of food, to keep it in good health. What suits the constitution of one will often not do at all for another.

\section{II-The WorK OF Worms}

A curious fact comes in here about the manner in which earth is changed into good mould. Some way back it was remarked that worms have a certain work of their own to carry out, and very important work too.

Many of us have perhaps looked upon worms as ugly slimy, useless creatures, unpleasant to handle. Well, they may be ugly, and they certainly are slimy. But useless they are not.

It is believed that they have no power of sight, though light does faintly affect part of their bodies; so far as is known, they have no means of hearing; 
their sense of smell at best is very feeble; and they do not seem to have any great amount of sense. So we cannot look on them as gifted creatures. Yet they have their task to do, and they do it perseveringly.

A part of it is the dragging of fallen leaves underground. Have you ever remarked how the piles of autumn leaves gradually disappear? They are not all swept up and carried away by gardeners. In a garden or a park this may account for a good many, but not in fields and woods. Yet there, too, in time they silently vanish.

And the worms have a hand here. They are believed to swallow a certain amount of the softer parts of leaves; and they draw goodly supplies into the soil for stopping up the holes of their burrows. If you keep a look-out you may sometimes find a twisted leaf sticking out of the ground only half pulled under by a worm.

Besides supplying the soil with dead leaves to serve as manure they take in large quantities of the soil itself as food. And this is all cast out again by them, enriched and improved and fitted for use. It has been said, indeed, that the whole of the soil in a garden or a field passes in time through the bodies of the worms, being thus prepared for its work.

One would never guess what numbers of worms are in the ground; sometimes as many as tens of thousands in one acre, or in one garden or field. Birds are perpetually after them, yet still multitudes remain.

One day I saw a blackbird that had just found a long fat worm. He had, no doubt, four hungry little ones at home, for he proceeded scientifically to cut the 
worm into four pieces, all the same in length. Then he tried to get the four into his mouth to carry away. The first two were easy enough, and the third was not difficult. But with the fourth he had hard work, for his beak really was too small. Perseverance, however, won its reward, and at length all four were firmly gripped, sticking out on either side like huge moustaches. Then he flew happily away to his family. But what the worm may have thought of the proceeding-if a worm can think!-is another question.

\section{III-Growing UP AND Growing Down}

A Root taken out of the ground seems a plain, dull, brown thing, not attractive. The leaves of a plant are pretty, and the flowers are often beautiful, and the fruit may be good to eat. But the root-who cares for the ugly root, buried out of sight? Useful, no doubt, since a plant without a root could not grow. But interesting-no !

Yet roots in their way are just as wonderful, and just as interesting, as any other part.

To give in few words the difference between a Root and a Stem is not quite easy. The stem comes from the root; and the two are so joined together that at a certain spot they are one. Often it is difficult to say exactly where the one ends and the other begins.

Some one may say, "Oh, that is easy! A root is brown and a stem is green." But many stems of trees are brown, and some roots are green-such as those of certain Orchids which grow in the air, and never go under ground.

It has been said that stems may be known apart 


\section{THE WORK OF ROOTS AND STEMS}

because they send out buds which grow into leaf-bearing shoots, while roots cannot do this. But here again the distinction fails. It is commonly true; yet roots are known, though they are rare, which do produce such buds.

Or again, we may say that a root is under ground and a stem is above ground. Only, as we have just seen, some roots grow in the air. And some plantsespecially ferns-have their stems under ground. What you see in a fern is usually not the stem with leaves on it, but the leaves alone. And you might easily take the underground stems for roots.

These, however, are exceptions. More frequently we do know a root when we see it; and we seldom make the mistake of supposing a root to be a stem, or a stem to be a root. A botanist knows that the two are quite different in their actual make.

Have you ever thought how singular it is that the roots should always go creeping under the soil, while the stems always rise upward into air and light-with just those few exceptions?

Why should they do so? Why may not the roots sometimes for a change try to come above ground, or the stems once in a while try for a change to go burrowing below ground? We never see this happen, with all the hundreds and thousands of garden-plants and forest-trees known to us. Such a thing is unheard-of. And why?

No explanation can be given except that which has been offered before: that it is their nature so to grow, and that He Who gave them life gave also to each its own particular nature and character. 
"The earth bringeth forth fruit of herself; first the blade, then the ear, after that the full corn in the ear."

Those words, spoken nearly two thousand years ago, still hold mystery. We have been trying to see something of how the soil is first made ready, by one means and another, so that it may be able to "bring forth" plant-life. But-like the roots growing under groundwe are still feeling our way very much in the dark with such difficult questions. We see what takes place, we "know not how" it happens. Only so much as we do see is full of interest.

Most of us can recall how Tennyson, studying a tiny plant, touched on these mysteries-

"Flower in the crannied wall,

I pluck you out of the crannies;

I hold you here, root and all, in my hand;

Little flower-but if I could understand

What you are, root and all, and all in all-

I should know what God and man is."

\section{IV-Tips aNd Hairs}

And now we have to think again about how roots behave under ground.

As they climb cautiously downward, into the dark moist earth, they send out branching side roots. When we pull up a plant we seldom fail to find such branching rootlets growing from the main root.

And if we examine them closely we may be able to make out a few tiny hairs near the tips of the rootlets; though most likely these could only be seen with the help of a magnifying-glass. 
It is very largely through these hairs that the roots take in food from the soil. All the young soft tips drink in moisture, but it is the tiny hairs which do most of the work.

A great deal of food is needed by the growing plant, and especially a great deal of water. You would hardly believe what a quantity of the latter has to be taken in. Those plants which live entirely in water have really very little that is solid in their make; and even with land-plants at least half of their substance is in most cases water, and often as much as three-quarters. So we can easily imagine what supplies of it a plant must drink to keep itself going.

In fact, a plant can in its way be just as hungry and thirsty as a man; and if food and water fail or become scanty it droops and gets limp and weak, just as a human being would do. This drooping of leaves and stem is often called "wilting."

Sometimes only a few root-hairs are to be found. Sometimes such numbers of them are crowded together, round about the root-tip, that it seems to be clothed in a kind of thick velvet. Their business is to suck up water, and at the same time they receive whatever of solid substances may be dissolved and floating in the water.

Root-hairs are really cells on the outside of the root-tip, and it is when need arises that some of the cells lengthen into hairs. Not only do they become long and thin, but also they gain a curious power to suck, so that they can draw away water and salts clinging to specks of soil : clinging, indeed, so fast that force is often needed before they can be dislodged. 
We have already heard something about living cells, in connection with the lowest forms of vegetable-life, and more must be said later.

Just now it is enough to observe that a cell is a very minute bag of living liquid. We could not by any possibility see one, unless in a most powerful microscope. But the whole root and all the smaller root-branches are simply made up of masses and masses of such cellsas, indeed, is the entire plant. They grow and change and alter their shapes, and gain fresh powers, and do different kinds of work, as may be required.

A word here about the food of plants found in the soil. Some mention was made earlier of " mineral salts," as they are called, which a plant must have if it is to carry out its proper work, and some of the most needful of such "salts" contain soda and potash, iron and phosphorus. These substances, taken in through the roots in liquid form, are worked marvellously into the living substance.

Among the pressing needs of all plants-we are thinking now of the higher kinds, such as grow in field and wood and garden-they must have a large amount of carbon, and they must have a large amount of nitrogen.

The carbon they get out of the air easily enough. And one might expect that they should get their supplies of nitrogen from the same quarter, since enormous quantities of nitrogen float in the atmosphere, much more than of any other gas.

But, strange to say, they cannot take and use nitrogen straight from the air. They cannot feed upon it at all when it is in what we call a "free" state-that is, by 
itself alone. They can only feed on it when it is united with some other substance. And plants in general have no power to bring about this union.

So the work has to be done for them. The "free" nitrogen is made ready for their use in the soil by numberless tiny specks of living creatures-the very lowest and smallest and simplest kinds of life, either vegetable or animal. They are called "Bacteria," and weak and tiny as they are they have this task to carry out. They have to capture the nitrogen gas, and to unite it with some other substance, so that it may become fit to be food for plants and animals.

It is only certain kinds of these minute "Bacteria" which have the power; and more particularly certain kinds that feed largely on the roots of beans and clover and other growths belonging to the same family, though not on those alone.

So the living specks of which we are thinking, hidden away in the soil, are doing two things. They are feeding on the roots of bean-plants or clover-plants; and at the same time they are busily making ready the food which those bean-plants and clover-plants must have to keep them in health.

You see now what an important question it iswhat kind of soil we put seeds into, year by year, whether in gardens or on farm-lands.

\section{And now to come back to roots in general.}

The root grows downward away from the light, and as it does so, gradually lengthening, its tip travels gently round, hunting for food like a live thing. And, of course, it is a live thing. The plant has life. 
All parts of the soil are not alike. Here may be found more water; there, less water. Here are more of such salts and other foods as are needed, dissolved in water; and there are smaller quantities. And the business of the root is to find out where it can get just that kind of food, and just that amount of water, which the plant must have if it is to grow and be in good health.

So, as the root gets longer and longer, its tips go steadily circling onward, making their way towards what is wanted.

If a root-tip touches a part which has the wrong sort of food, or not enough water, what do you suppose it does? It simply turns aside and tries elsewhere.

And when it draws near to a part where there is abundance-what then? Why, it goes in that direction, and the tips on arriving at the place send out tiny root-hairs to suck in food and water.

Far away in the cold north the ground is always hard-frozen a little way below the surface, not only in the winter, but all the year round. Many shrubs and fir-trees manage to flourish even under such difficult conditions, helped by the sun. And the roots of these plants start off just as do others farther south to travel straight downwards.

But before long they come near to the hard frozen under-soil. What do you think they do then? Would you expect them to go steadily, doggedly, boring onward into the ice?

Not they! As soon as they get near to the frozen soil, and before they reach it, they make a sharp bend, and journey along keeping to the same level, going no 
deeper down, and so remaining in ground which, through the summer, is not frozen hard.

\section{V-A Plant's Brain}

In all that we have been discussing with regard to the roots of plants, one thing is clear, that they certainly behave as if they had some sort of dim sense, or at least as if the plant as a whole had.

More than this we can hardly venture to say, for it is a very difficult question altogether. But so wonderful are the roots in the way they go prowling under ground, not only hunting for food, but apparently choosing just the right food for their own particular growth, that they have even been named "The Brain of the Plant." So a plant's brain seems to be, not as with us at the top of the structure, but down at its feet.

We need not, indeed, imagine that a plant can really think and understand. All we know is that it certainly has wants; and that it can respond to-can turn towards - that which will satisfy those wants.

When root-tips are spoken of as travelling round and round, no rapid movements are meant. If we were watching ever so long and so carefully we could not see those movements. They are real, but they are very slow, very gentle, very gradual.

Now what do you think becomes of all the water and liquid food sucked in by the roots?

It passes first through the hairs into the side roots, then on into the main root, and thence it journeys upward by way of the stem or trunk. Its name at this stage is "raw sap" or "crude sap." It is thus far 
only the "raw material," not yet fashioned into what it is meant to be. It has to go higher still before it can be altered and moulded and shaped.

And here we come to one of the chief uses of the stem or trunk-the "body" of the tree. Just as your body is used for the carrying of blood to every part of it and of its limbs, so the trunk of a tree is used for the carrying of raw sap to every part of it and of its branches; and,

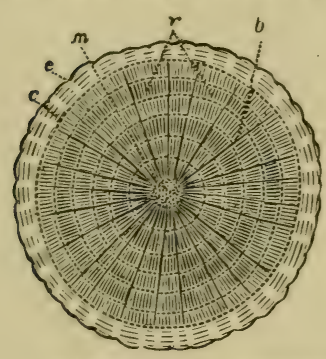

TRANSVERSE SECTION OF AN OAK BRANCH, SIX YEARS OLD : $m$, pith or medulla; $c, e$, bark; $r$, wood; $b$, medullary rays. later, for the carrying also of the manufactured and finished sap to wherever it is needed.

While winter cold reigns over the land the life of a tree is at a low ebb, and all outer active growth has come to a standstill. But this does not mean complete idleness. Within the trunk, and within the branches, preparation for spring has not only begun, but may be far advanced. If leaf-buds and flower-buds are not actually formed-and each kind of plant does differently in such respects - they are slowly taking shape, and they -will be ready in time for warm spring sunshine. For the present all is quiet, and growth is sluggish, and the roots have not nearly so much to do as they will have by and by.

It is very much the same with a tree in winter as with ourselves when we are asleep at night. All day long while we are on the go, actively employed, we need plenty of food and water; but in bed we can sleep for many hours wanting neither. Yet all night long 


\section{THE WORK OF ROOTS AND STEMS}

we are alive, and the beating of our hearts and the taking in of air by our lungs go on as usual, though the body is quiet.

All through the winter a tree is alive, and work is going on inside it, though it needs little food or drink. Not till the beginning of spring, the first arrival of mildness, are active growth and change seen by us; very early in the spring with some kinds of plants, and not till almost summer with others, but always with the coming of sun-warmth.

Then, indeed, the root-hairs start upon their task with energy; and quantities of liquid are sucked in to find their way upward through the roots into the trunk and branches.

And thus comes about one of the greatest marvels known in Nature. But of this we must speak in another chapter.

"Full many a glorious morning have I seen

Flatter the mountain-tops with sovereign eye, Kissing with golden face the meadows green,

Gilding pale streams with heavenly alchemy." 1

"Lo, here the gentle lark, weary of rest,

From his moist cabinet mounts up on high, And wakes the morning, from whose silver breast

The Sun ariseth in his majesty:

Who doth the world so gloriously behold, The Cedar-tops and hills seem burnished gold." 2

1 Shakespeare.

2 Ibid. 


\section{PART VI}

THOSE LITTLE WORKSHOPS

I-The Rising of SAP

Aт the end of the last chapter we had just come upon one of the greatest wonders known in Nature.

All the water that is drawn in by the roots of a tree does not stay there. It passes from the hairs into the root-branches, and then by way of the main root into the trunk. After which it mounts up and up, through tiny channels, till it gets to the lower boughs.

And it does not stop there. It sends out a sidesupply into each bough in turn as it passes; while still the chief amount goes on, climbing higher and higher, till the top of the tree is reached and every part has had its share.

Sometimes the sap - as yet in its " crude" or unfinished state-has a long journey. Many of our forest trees are fifty feet, eighty feet, a hundred feet high, and often much more. Trees in other parts of the world, such as the Wellingtonia in America and the Eucalyptus in Australia, rise to a height of two hundred or perhaps even three hundred feet. Yet the supplies of sap rise to the very topmost twigs.

Think what a marvel this is, this steady upward climb of the raw sap which takes place each springtide in every plant that lives and grows, in each herb, 


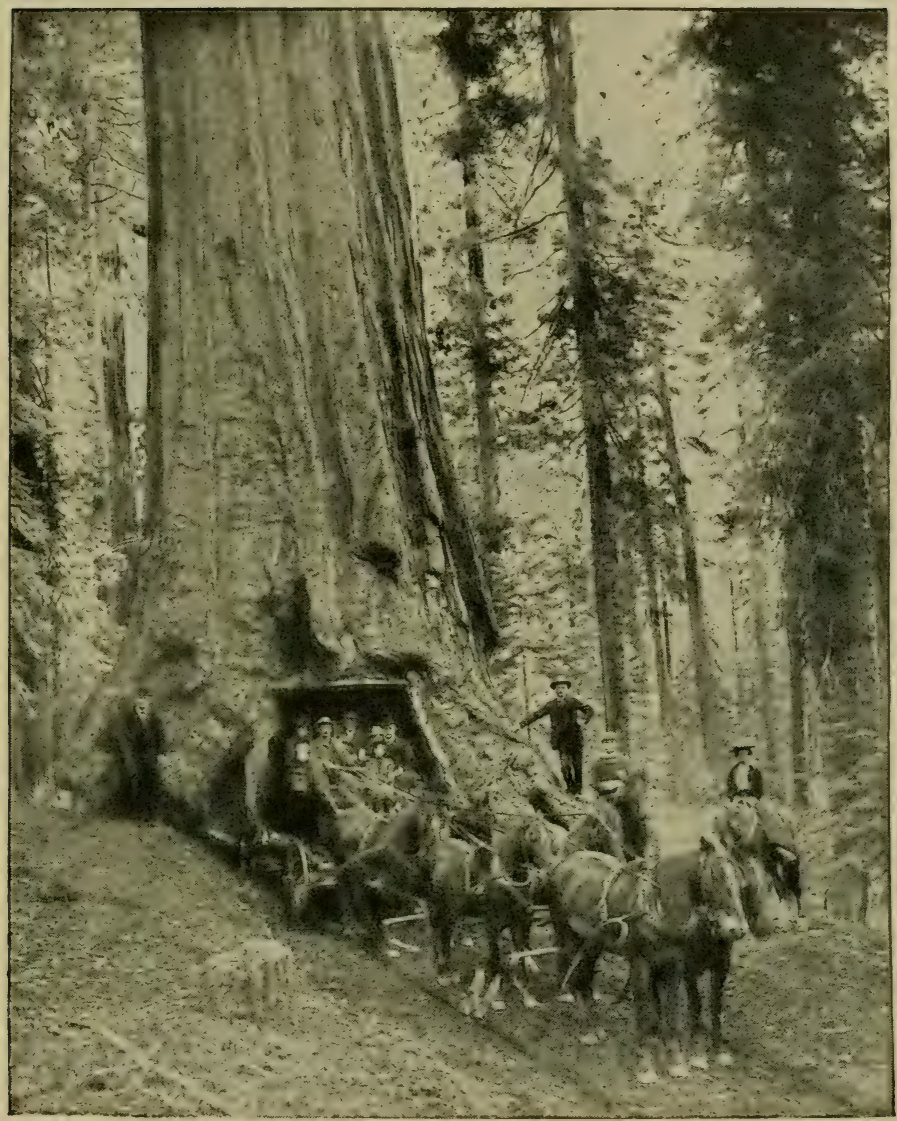

GOVERNOR ODELL AND PARTY PASSING THROUGH A WAWONA TREE, CALIFORNIA.

each shrub, each tree, in garden and field, in wood and forest, throughout the whole world. 
We know that things are so. But how does it come about? That is no easy question to answer.

Water and all liquids pour downward, never upward. Not once in our lives have we ever seen a stream running uphill. If we tried to any extent to make it travel thus we should fail. For the strong attraction of our Earth, perpetually at work, draws everything towards the ground, from higher to lower levels; and water because of its fluid make responds quickly to that pull. So it always flows downward to lower levels.

Except in this case! And here we find just the opposite. Here we have water in large quantities, taken in by the roots, mounting steadily to the tops of the highest trees, going as it seems to us right in the teeth of that tremendous earthward pull which we call "Gravitation" or "Gravity."

No easy matter this to account for. Many explanations have from time to time been given, but even when taken all together they cannot be said to explain fully what goes on.

It was long believed that the rise of sap was due to a certain form of attraction which is found in very small tubes. If you hold upright in water a tiny glass tube, you will see that the water inside rises just a little higher than the water outside. For the sides of the tube, attracting the water inside, draw it slightly upward. With a very minute tube indeed, the water would rise much higher.

Now a tree-trunk contains millions of most slender tubes. Some of them may be as much as two or three feet in length, and they lie up and down the trunk, 
not across it. Such tubes have been named "channels" and "water-pipes" and "water-mains," because of the quantities of water filtering through them.

In a tree which has begun its growth with two small seed-leaves these delicate water-pipes lie chiefly between the bark and the wood. But in a tree which has begun its growth with only one small seed-leaf they run throughout the whole trunk.

It was argued that the sap, reaching each of these tubes in turn, would be naturally drawn upwards by this particular kind of attraction, which is known as "Capillary," from the Latin word for " hair." Each of our hairs is really a tiny hollow tube. But though, no doubt, there is truth in the explanation, it is not enough by itself, not nearly enough, to account for the mystery.

\section{II-Other Suggestions}

A different idea, more lately put forth, is less easy to make clear. It has to do with the "make" of the cells and tubes of a tree.

Both cells and tubes, little round cells and long slim tubes, are clothed in a most fine and delicate skin, which is called by the same name as the thin outer skin of our bodies-the "cuticle." And the tubes are not open at either end like a glass tube. All these cells and all these tubes are closed at both ends.

As the sap rises in the tree it has to make its way right through this skin before it can go from one cell or one tube to another. It finds no tiny open doorways. The whole tree-trunk is divided into millions and millions of little compartments, and in every few feet of 
its upward journey the sap has to pass into and out of countless multitudes of them. This is a very different matter from a clear run through one long channel, and it is impossible fully to explain.

The subject as a whole is far too difficult to be gone into here. All I can tell you is that the sap does so journey from cell to cell, from tube to tube, filtering gently through the enclosing skins. Not only in springtime upwards to the leaves, but later on, when it has been fashioned into the completed sap, it travels again in like manner, away from the leaves to all parts of the tree, both above and below, wherever it may be needed.

One other fact, which bears on this question of the rising sap, is easy to grasp. You have heard how the roots suck in liquid and send it upward. Such constant pressure from below of more and more sap ever rising must, it is thought, help the forward movement of that which is in front, very much as people in a dense crowd are pushed on in front by the pressure from behind.

Also the constant giving off by the leaves of quantities of water is believed to lend some little assistance. Water vapour is poured into the air from tiny leafpassages, and as it goes, more and more water is needed from below to take its place.

So we may say that probably both the roots and the leaves do, to some extent, lend their aid in the upward journeying of the raw sap. But with all these proposed explanations it cannot be said that the rise of the sap is fully understood.

Perhaps hardly anything is more surprising than the 
energy with which the small root-hairs suck in water and despatch it on its upward climb. Still, one naturally asks why this remarkable energy, begun in the roots, should last unbroken until the mounting sap has gained a height of one or two hundred feet or more above the ground? Why does it not die down, long before then, under the ceaseless drag of Earth's attraction? And again, what is it which gives such energy to the tiny hairs? - a force which, it has been said, goes beyond that of a boiler in a steam-engine!

One great cause, and one alone, may be spoken of as meeting the entire difficulty. Not as explaining it, not as showing precisely how the work is done, but simply as stating to what it is due.

All this wonderful energy, this force of movement, this persistency of work, this growth and change and development, spring from the LIFE of the tree. That Life is in its very nature active, energetic, aspiringwhich means that it must climb upward. It cannot rest content where it happens to be. It must strive after something ahead. It works and it must work, just because it is Life.

But we can no more explain fully the "how" than we can tell exactly how it is that the life in your body keeps your heart and lungs working, day and night unceasingly, without any effort of your will. We only know that things are so.

In the same manner we know that the life of a treethe life that is in the tree-accounts for the work of the roots, for the energy of the root-hairs, for the rise of the sap, and for countless other wonders. 


\section{III-How Many Leaves?}

The sap, having reached the boughs, passes into the twigs, and thence onward into each separate leaf.

For this purpose it has climbed the trunk-that it may get to the leaves. They have a great task to carry out, which they could not possibly do without the raw sap to manipulate.

Each leaf by itself may be regarded as a small workshop; this has been said earlier. And the "crude sap" brought to it by the channels of trunk and branches is as the "raw material" brought to a manufactory.

"Pig-iron," for instance, is taken to great ironworks, to be there transformed by many complicated methods into all kinds and varieties of iron and steel goods. Or, again, a different class of raw materials may be conveyed to a soda manufactory, and after many processes the finished article, soda, is produced for uses innumerable.

In like manner the raw sap is brought to the leaves of a tree, to be transformed into many diverse substances, needed by the tree itself for its own use, and needed also by human beings.

These "workshop" leaves are always green, except when they first open out in early spring and when they fade in autumn. In the spring many of them show pink and salmon tints, but that is before they begin their real business. And in the autumn they often turn yellow or red, but that is when their task is done. The life of a leaf is both short and busy. No idlers are they, these useful little friends of ours. 


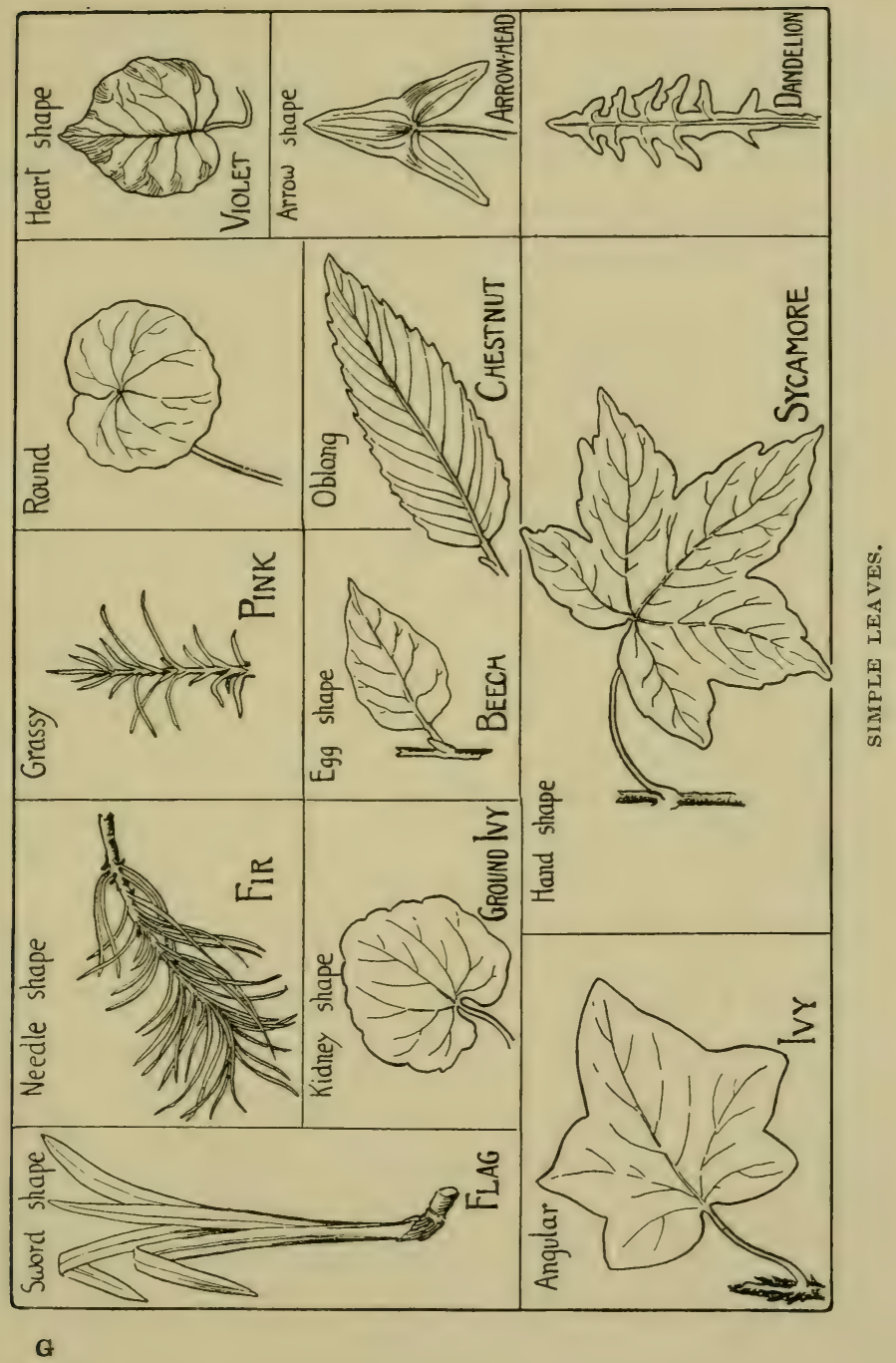


They take in hand the raw materials, which are dissolved in water and brought to them from the soil, together with the gases which they receive from the air; and they work up these materials and gases into what is known as "Organic Substance" - that is, into such a substance that LIFE CAN WORK IN AND THROUGH IT.

Life cannot work through all kinds of substance. It cannot, for example, through marble or granite. But when the leaves have prepared this "organic substance" it has become fit for food of animals and men, for Life can enter into it and can use it.

Each day with early dawn the toil of the green substance of leaves begins. At night, in hours of darkness, it rests; but no sooner does sunlight return than it is once more hard at work.

How many leaves would you imagine to be on a tree? Counting is no easy matter with one of any considerable size, they cluster in such dense masses. But a reckoning was made with an Oak, probably a large tree, for the result gave about seven hundred thousand leaves! What, then, must be the multitudes in a wood, in a forest, in the whole world?

Not only are their numbers enormous, but their kinds and shapes and varieties are endless. Some are large, some small; some are thick, some almost transparent; some are strong, some fragile; some are long and narrow, some short and broad; in fact, every imaginable description of make may be found.

And they grow so differently: some in pairs, one opposite another; some alternately; some in circles or "whorls" around the stem. 
A few years ago, when I paid a visit to the Kew Gardens, I came across remarkable leaf-specimens.

Near the main entrance was a bed of plants, standing about eight or ten feet high, with very big substantial leaves, handsomely veined and ribbed, many of them measuring a good two feet across and the same in length. This was the "Kiri" plant. But others go far in size beyond those of the Kiri.

In one of the houses was a lovely fern from the tropics, the "Dicksonia." It has a woolly protective covering for its stem, and graceful fronds or leaves, fully ten feet long.

And yet another great tropic plant-the "Cohune Palm "-boasted a leaf actually thirty feet in length. It was deeply cut down to the mid-rib, but still the whole was one leaf.

Such a specimen can hardly be spoken of as a small workshop. It is more like a large manufactory.

"The leaves of the winter wither and sink in the forest mould,

To colour the flowers of April with purple and white and gold." 1

\section{IV-ThE MAKe of a LeAF-}

Now as to the make of a leaf: how it is built up or put together.

It is said to be in three parts : the Blade, the Footstalk, and the two Stipules, which look like small leaflets, just where the footstalk begins. But often no stipules are found; and often, too, is seen no footstalk. The really needful part, without which we should have no

$$
1 \text { Alfred Noyes. }
$$


leaf, is the blade, the wide green portion. This reminds one of an oar, the chief part of which is called "the blade."

A leaf, like all the rest of a plant, is formed of countless tiny cells, pressed and growing together; and the mass of these, green in colour, is known as the "cellular tissue" of a leaf. This word "tissue" means strictly "that which is woven"; and here it stands for the kind of substance which may become part of a living body, either of plant or of animal.

The ribs and veins of a leaf-its skeleton-are also formed of cells; but these cells have hardened into a tough substance, which is fit to act as a strong framework for the soft tissue. And over the whole is a fine transparent skin or cuticle, both above and below, through which the green tint can be clearly seen.

In this skin are numbers and numbers of extremely minute openings; tiny pores or holes, so formed that they can open or close according to the needs of the plant. They are indeed so tiny that they cannot be seen at all without a powerful microscope. If you were to prick a hole in paper, with the point of the very finest needle, that hole would be simply huge side by side with a single leaf-pore.

By far the greater number of them are on the undersides of leaves. No doubt this is because the underside is the more sheltered, and not nearly so much exposed as the upper-side to rain and wind and dust. And each of them is the doorway to a minute channel or passage, leading to and from the inside of the leaf.

No one would guess how great is the number of these 
little pores-or stomata, as they are called. A single Oak-leaf, for instance, was reckoned to have on its under-side alone more than two millions. Some of the largest known are on the leaves of Orchids, and some of the smallest are on the leaves of Water Lilies. But all
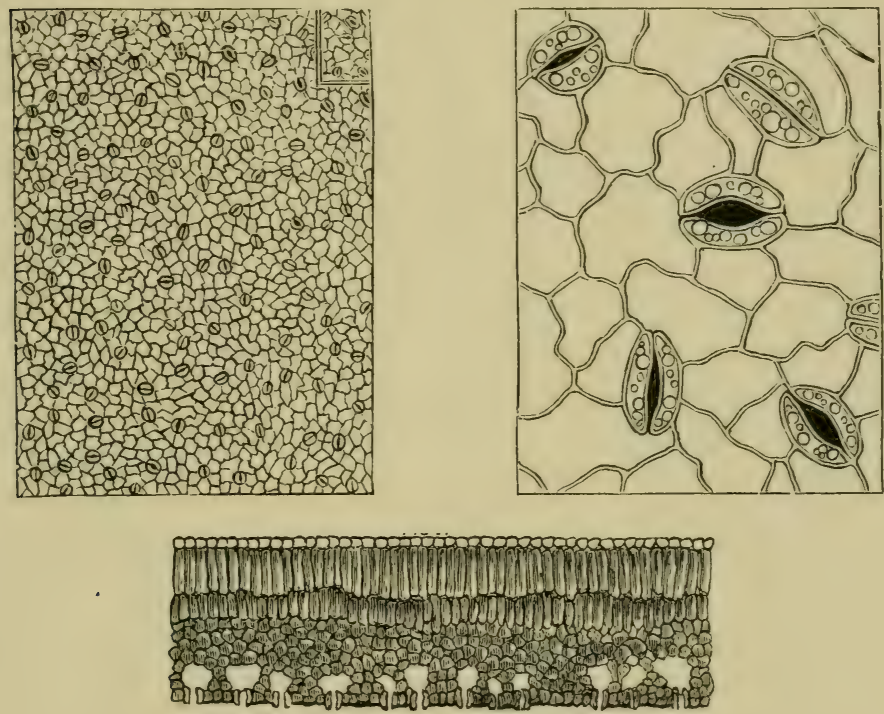

STOMATA.

are tiny. They are most useful, most necessary, for the life of the plant. They have to let in and to let out supplies of both air and water-vapour.

A plant-any kind of plant-must do three things, not unlike what we have ourselves to do. It has to breathe. It has to digest. It has to transpire. This 
last word means that it has to get rid, through its skin, of water not wanted for its own use.

Would you have thought of a tree being obliged to breathe? But indeed it must. It cannot live without breathing. Like a man, it must have oxygen gas, or it will die of suffocation; yes, of actual slow suffocation. A tree breathes day and night; summer and winter.

A man breathes by means of his lungs. But a tree has no lungs; and it breathes in all its parts that are actively alive-its roots, its green stems, its seeds, its fruits. If the roots cannot find enough air in the soil, then the whole tree suffers. It also breathes by its leaves.

When a man's lungs receive the air which he has drawn in, they make use of it for his body. A kind of burning goes on within him, much as when fire burns away wood. The oxygen of the air is united with some of the carbon of his body, to make carbonic-acid gas; and this is poured out again into the atmosphere. It has to be got rid of quickly; for if not, the man would die.

And the same thing goes on in a tree, in any kind of plant. There too, the oxygen of the air, which has flowed in through countless little pores, is united with some of the carbon of the tree, and carbonic-acid gas is formed, ready to be poured forth into the atmosphere.

\section{V-AND THE WORK OF A LEAF}

Thus far the tree does much the same as we do. Here we come to a difference.

It has to digest, as well as to breathe. That is, it has to take in food, and to make that food a part of itself. 
Like ourselves again! But a man digests his food by means of his stomach; while a tree digests by means of its leaves.

So the leaves have to carry on two separate tasks at the same time. In breathing, they capture air with its life-supporting oxygen, and get rid of carbonic-acid gas. But in digesting, they again capture air, and do just the opposite. They keep for food the carbonic-acid gas-which is more strictly known as carbon-dioxideand they get rid of the oxygen. Green plants and all green portions of plants feed very largely on carbonicacid gas; for it is much needed in building up the substance of a tree.

Both men and plants in breathing make the air around less healthy, because they keep taking away from it oxygen gas, and adding to it carbonic-acid gas. And if this went on perpetually, with nothing to undo the harm, our whole atmosphere would in time become impossible for us to breathe.

But there is a something, and a very big something, to undo it. There is the work of leaves, of grasses, of countless millions of them in all parts of the world, taking in carbonic-acid gas as food, and pouring out enormous quantities of oxygen gas, so needful for life. While they breathe like ourselves, thus helping to render the air unfit for us to breathe, they also by their digestion set the matter right, and keep the atmosphere pure and good.

They are doing it always; but not all plants in the whole world incessantly. Day after day, and month after month, they carry on this work in relays. Each 
plant works thus only in daylight. The breathing of a plant goes on, as with us, both by day and by night. The digesting takes place only while it is light. After dark, it stops. The tree then just breathes as we do; keeping the oxygen of the air for its own use, and getting rid of the carbonic-acid gas.

And so soon as morning light returns, they are once more at their useful work; and while they still breathe out carbonic-acid gas, they catch it up again as it leaves the little pores, and use it anew as food for the plant to which they belong.

You would never guess what accumulations of that important but suffocating gas are being manufactured, day and night, through breathing. Putting aside what plants and animals do, and reckoning only what is done by men and women and children throughout the world, it is said that each day more than one million tons of carbonic-acid gas are poured into the atmosphere.

So no wonder the daylight task of plants is needed, to undo the mischief which we ourselves are perpetually working.

"Small service is true service while it lasts;

Of humblest friends, bright creature, scorn not one.

The Daisy by the shadow that it casts

Protects the lingering dewdrop from the sun." 1

Something has already been said about a tree having to transpire. This really is a kind of perspiration.

When a man perspires, drops of water are seen on his face; water that has oozed out through tiny pores in his skin. When a plant "transpires" the water escapes through its skin-pores, as invisible vapour. But

1 Wordsworth. 
a man really transpires, as well as a tree. All day long water-vapour is escaping through the pores of his skin - about as much as one pint in twenty-four hours. This is sometimes called "insensible perspiration," because we do not see or feel it.

Plenty of water, as you now know, taken in by the roots, mounts upward by way of the tree-trunk into the leaves. And in each drop there may be, at the least, a few specks of some other kind of substance, needed by the tree.

Such tiny specks!- the very smallest that we can imagine!-so minute, so light, that they float in the water unseen, and can pass with it through the delicate skins of the cells and tubes. Yet, tiny though they are, the tree must have them, if it is to carry on its work.

As they pass they are caught hold of and kept back and made use of by the leaves. And all the water that is not wanted is sent on to the leaf-pores, to escape as vapour into the outside air.

This is yet another work done by the leaves. Not only do they help to make the air more pure, but also they help to keep it well supplied with moisture. Here, too, we have to do with large quantities. Immense amounts of water travel thus, from the soil upwards through the tree-trunks, then out by way of the tiny leaf-pores, into the air which we breathe.

It has been reckoned that a well-grown Apple-tree, in the course of a single spring and summer, may part with something like two hundred and fifty pounds' weight of water. If we count the trees growing in one large orchard, we can soon find out how many tons of water are poured through them in a year. The total 
is astonishing-all the more if we picture to ourselves the weight of a single ton.

And since one orchard alone can do so much, what must be the supplies which are in this manner got rid of by all the orchards-all the gardens-all the woods and forests-in our country? For not only are trees engaged in the task, but plants of all descriptions as well, including grasses, ferns, and mosses.

\section{VI-Green Leaves}

We have now seen that these little "workshops" have their "raw material" brought to them in two ways. First, from the roots upward through the stem; and second, by the leaves themselves inwards from the air. First, water, with invisible specks of many kinds floating in it; and second, air, with its mixture of different kinds of gases.

From these two sources the leaves are able to work up or to manufacture many "finished articles," as we may call them; such as sugars and starches, and fatty and oily substances, perpetually needed by men; many of which can be obtained in no other way.

Two wonderful powers work together for this end; each helping the other.

One of the two is in the leaf itself. It is, the Life in that leaf. We have noticed earlier the extraordinary vigour found in life; and here we find it again-the power to work, to grow, to do.

Throughout the whole tree, in all the active cells of which it is or has been made-" has been" because parts are always dying as fresh parts grow-in these 
active cells a certain something is found, the presence of which means the presence of Life. Where that something is, that part of the plant is alive. Where it is not, that part is practically dead.

This something is also in those specks of vegetablelife, the very lowest kinds known, of which you heard some time back. Each little plantlet by itself may be only one single cell; a mere bag of liquid. But it has in it this mysterious substance-soft, slimy, colourless. It holds the germ of life; and so it is a living, breathing plant. And every active cell in every plant has in it the same; without which it would not be alive.

Such living cells, whether each one is a separate plantlet or whether it is part of a larger plant, have power to work, and to shape and mould other substances. As has been said of them-they not only " provide the building materials, but they are themselves the builders."

And what marvellous building it is !

Plants by millions throughout the world, all of them living, growing, working. Yet each plant, no matter how great, has always begun its life as one tiny cell. From that cell came others, shaped first inside itself, and from each of those more and more cells, till at length a seed has taken form; and from the seed comes a new herb or tree.

And now to go back to the leaves; our busy little workshops.

They, too, are built up of multitudes of cells, each of which is lined with this living substance. But now we touch upon something else, not always found with it. 
For here are numberless tiny green specks, which lend their colour to the leaves. All through the green leaves of plants, and the green blades of grasses, and young green stems and shoots, they float in vast hordes. They are found also, to some extent, in the petals of flowers, in seeds and fruits, and even in roots; but not nearly so abundantly.

And it is only where these little green specks congregate, that the work can be done of which we have been thinking-that particular work which is given to leaves; the taking up of lifeless materials from earth and air, and so changing and fashioning them into new substances, that they are fitted to become food for animals and men.

A curious fact is that the living cells in a leaf first make this leaf-green; and then, having manufactured it, they use it for their tremendously important work.

"How can they possibly do all this ?" you may ask; and indeed you may well ask it! In one sense I can give no clear answer. In another sense I can. For here comes in the second great power; and that power is-Sunlight.

Sunlight and leaf-green work together in a happy comradeship. Without the Sun, the leaf-green could do nothing; and without the leaf-green ${ }^{1}$ the Sun could not carry out this task. Each apart from the other is powerless to break up the carbonic-acid gas of the air, keeping the carbon for the building up of the tree, and setting loose the oxygen for us to breathe. Each, apart from the other, is also powerless to provide in

1 The "leaf-green" is known by the name of "chlorophyll," from two Greek words for "green " and "leaf." 
enormous quantities that "finished material" without which neither we nor animals could feed and live; without which the whole world would soon become one vast desert of death.

But why, and how, and in what precise manner, the great blazing Sun and the tiny invisible green granules work together to bring about such grand and worldwide results, no man living can fully explain.

"We on this earth are servants of the Sun, Out of the sun comes all the quick in me, His golden touch is life to every one, His power it is that makes us spin through space. What we may be, who knows? But every one Is dust on dust, a servant of the Sun."

1 From Lollingdon Downs, by John Masefield, published by W. Heinemann. By permission. 


\section{PART VII}

\section{THE POWER OF SUNLIGHT \\ I-Flowers in Sunshine}

You remember how the Daisies on the lawn lifted up their faces towards the Sun. And Daisies do not stand alone in their seeming love of sunshine. Many other flowers depend even more upon it.

For example, Sunflowers are looked upon as great Sun-lovers. Some of them really are too huge for beauty; such thick yellow masses! The name was given to them because of their devotion to light. It has been said that no Sunflower is ever seen with its back to the Sun.

This perhaps is not quite correct; for if the plant were not in good health, and if in consequence the stalk were weak, the flower might not be able to carry out such movements. But no doubt it would do its best.

A gardener told me that, one day many years ago, he saw in Kew Gardens two great beds of these flowers, in full bloom. And among them all, large and smallsome plants standing ten feet high-he found not one single bloom that did not face the Sun.

The same thing may be seen with the curious rolled leaves of an Onion-plant-not a Shallot.

If we should examine a row of them in the evening, towards sunset, we should probably find the greater 
number of leaves pointing towards the rest, where soon the sun will go down. But if we pay them another visit next morning, not too early, when the Sun has been some hours up, a change will have taken place. Many if not most of the tube-like leaves will have probably managed to turn over more or less towards the east,

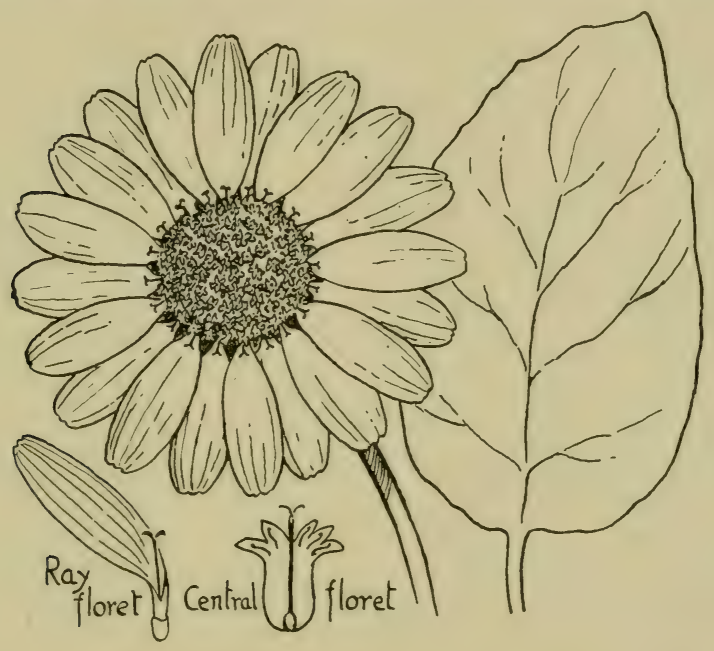

where the Sun arose. Generally there are a few weakly or sickly ones, not able to do this.

For plants, like men, are by no means always in good health. They suffer from weakness, and from various diseases, partly due to bad air or bad water or not enough food, just as with ourselves.

The same apparent love of sunshine is shown by other kinds also. Some time ago I came across a Viola-plant 
in a garden, growing in a narrow bed which ran beside the drive. It was fully in bloom, with a crowd of pretty mauve-blue faces, turned smilingly upward.

They were marvellously arranged, so that each one might obtain as much light as possible. No attempt had been made to follow the Sun in his journey across the sky; for it would have been useless. The hedge behind, and a wall in front, cut off much of the direct sunshine, except at one certain time of the day. But the plant had plainly done its best so to place its blooms that, when the sun did come, they could make the very most of him. And when he was gone, they would still be in a position to get all the light that might be obtained in that position.

It was so cleverly managed! Of all the seventy or eighty flowers-I forget the exact number-not one lay behind another.

Many were touching at their edges, because there was not too much space for them all. But they had so spread themselves out as to find enough; making a lovely pattern of delicate blooms, side by side or one above another, close together, yet each one clear of the rest. Only in one spot, I think, did I find a single small corner of a petal behind the next flower, and that was because it really could not be helped.

And all this was worked out by the plant itself. Is it not wonderful?

Of course I do not mean that the plant thought it out, as you or I might do. It is more like what goes on perpetually in our own bodies - the living, the growing, the putting-on of flesh, the breathing, and so on, without any conscious effort of our own wills to bring it about. 
A plant cannot think, or reason, or resolve what it will do. But certainly it does often act as though after a fashion it knew what is good and needful for its growth and health. The way in which it manages to gain all possible sunshine for flowers and leaves, and the way in which it takes in and uses materials gathered from earth and air and water-are very marvellous.

It was pretty to see how gently matters had come about in this particular instance. If a party of human beings were all together, wishing to be in full sunshine, and if the space in which they could move were small, they might be tempted to think first of themselves, and to push others into the shade.

But the Violas had done no such thing. They had just spread themselves softly out, as far as they could, without any pushing. It really did look almost as if each one had tried, not only to get plenty of light for itself, but also not to hinder its neighbours from doing the same.

On one other occasion I remember noticing this eagerness of Violas for sunshine. It was on Sunday, in the country and in early morning. On my way to church, I saw a little grave in the churchyard full of them, in full bloom. And though it was so early, and the Sun had risen no long time before, yet each little face was turned towards the east, right upwards in his direction, as if rejoicing in his beams.

"The heart that has truly loved never forgets,

But as truly loves on to the close-

As the Sunflower turns on her god, when he sets,

The same look which she turned when he rose." 2

1 Thomas Moore. 


\section{II-How THE WORK IS DONE}

It must not be supposed that all plants need the same amount of sunshine. Just as with ourselves, that which is good for one is not always good for others.

Some can hardly have too much, while others droop quickly under heat and glare. Some flowers, like the Viola, lift their faces upward towards the Sun, while others, like the Violet, creep under sheltering leaves. A Viola is more like the sunshine-loving Heartsease. ${ }^{1}$

But, taking the question as a whole, we may say that plants in general undoubtedly do need, not only light, but sunshine also. Without warmth there can be no growth; and more warmth, though not too much, means usually more rapid growth. For the special work of green leaves, sunshine is particularly needed.

As with flowers so with leaves, you may note if you will how carefully they often seem to arrange themselves, that they may get the greatest possible amount of light. In a plant it can be seen frequently that the leaves-like the Viola blossoms-have most of their upper surfaces turned towards the Sun, spread out level to catch his beams.

With a large tree, where the foliage grows in dense masses, many parts must be more or less in shade; yet the same result is here aimed at. Each leaf at least tries to obtain its share of sunlight.

Something else is worth noticing, in the way that leaves are arranged. Very commonly they grow in a

1 All three are species of Viola. 


\section{THE POWER OF SUNLIGHT}

kind of pent-house style, sloping gently outwards, one above another, so that rain, pouring on them, is guided away from the trunk.

A reason for this may be conjectured. Do you remember that it is the soft tips of the roots, where they are clothed with hairs, that suck in moisture from the soil? But in a tree, with its widely spreading roots, those tips are far away from the trunk, often many yards distant. Rain, falling close to the trunk, is not needed; while at the root-tips it is much needed. So when the sloping leaves throw it outwards, it falls where it is wanted.

At times we may see leaves doing the opposite. If on a rainy evening, after a dry day, you pass a patch of potato-plants, some of the leaves may be tilted up, standing on end and twisted as one might twist a piece of paper, to form a channel for water. Thus again they guide the falling drops to the roots, which in a small plant are not far from the stem.

However, this curling of the leaves may arise from another cause. Many leaves, which all day long have turned their upper surfaces broadside to the sun, will droop and curl at the coming of night.

For at night heat pours quickly away from the ground, and from all upturned surfaces; and the leaves in that position might suffer from cold. So, perhaps, it is mainly on this account that they no longer face upwards. Such drooping and turning away has been called "the Sleep of Leaves."

It is not real sleep with them, as with us. It is simply a movement, placing the leaves-often also the flowers-so that they may keep a little of their warmth 
until the morning. Yet their so doing may be of use to the plant in the two ways named above.

Leaves, as we have seen, are called upon to carry out many and varied tasks. But of all that they have to do, not one is more necessary for ourselves than the wonderful way in which they transform the raw sap into all kinds of food and other useful substances.

A very remarkable part of the matter is that each kind of plant should always make its own especial material, and should always go on making it. Through years, through hundreds of years, still plant after plant, shrub after shrub, tree after tree, manufactures always and only its own particular " brands," and never any others.

Different plants may grow side by side, using the same air, the same earth, the same water; and yet the "finished article" turned out by each is not the same.

One kind brings forth poisonous berries. Another brings forth a delicious fruit. Another brings forth a remedy for illness. Another brings forth something of use in our household work. Another brings forth that which we need for clothing. But always, always, the same thing is made by the same kind of plant.

And this means that each plant uses for its work exactly the right materials. It chooses out those substances, from the various supplies which travel to it in air and in water. It refuses the wrong ones and keeps the right ones, handing over the latter to the leavesits small workshops. And the leaves, busily toiling through the few months of their brief existence, always turn out that particular article which they and their kind alone are able to produce. 
The make of the soil is thus of great importance. It may be good or bad for the plant. It may be too dry or too damp. It may be lacking in just that description of food which is necessary for the particular manufacture of that plant. If the soil be good, the plant will be healthy, and will work with vigour; if bad, then the plant must become sickly and feeble. But still in every case each one produces, and can produce, only its own especial materials.

"Ask me why I send you here

This firstling of the infant year;

Ask me why I send to you

This Primrose all bepearled with dew.

Ask me why this flower doth show

So yellow, green, and sickly too;

Ask me why the stalk is weak

And bending, yet it doth not break;

I must tell you, these discover

What doubts and fears are in a lover." 1

\section{III-Plant Manufactures}

By far the greater part of this complicated work is carried on by the Green Leaves of plants, though not the whole of it.

One exception is in the matter of Wood. Our larger trees contain masses of wood. In the trunk is the softer sap-wood, close to the bark, full of tiny channels through which the sap journeys. And also there is the heart-wood, filling up the centre with hardened remains of channels, through which the sap no longer passes; and that part is nearly dry.

1 Thomas Carew (about A.D. 1600). 
"How does the wood come to be there at all?" one may ask; and perhaps you would answer, "Why, it grows! It is the trunk itself." Yes, it is; but it has to be made. It has to be built up, year by year, within and by itself, layer upon layer. And even there, though in a sense the leaves do not carry on the work, it is more or less due to them. For if they did not faithfully perform their share, by changing the raw sap into finished sap and sending it back through countless channels to nourish every part of the tree, no wood could grow.

Other materials, such as rubber, are made in the stems of trees, and not actually by the leaves; and the same may be said of seeds and fruits, formed in and by the flowers. Yet in all these cases the leaves lend a hand.

From early morning till evening they are at it incessantly; gathering air and water; choosing the materials that they need; working all up under the sun's rays; and turning out in the end that which it is their duty to produce.

Then at last the completed sap is ready. And the different uses of it, made by different plants-the varieties of substances brought forth-are simply amazing.

Some serve for the food of the growing plant itself. Some are meant for the support of young plants in the future. Very many are food for animals and men.

Indeed, the greater amount of food, upon which our lives depend, comes to us in this way. We get it straight from plants by eating fruits and vegetables, roots and 
stems, either cooked or uncooked. We get it by eating bread and pastry, cakes and puddings, made from the flour of wheat or oats or other such growths. We get it by eating animals which have lived on vegetable-food. We get it by eating animals that have fed on other animals which have lived on vegetable-food.

So again and again we come back to the work of leaves. Such numbers of substances, needful for the support of life, have to reach us thus!

For neither we ourselves, nor animals in general, have any power to take food-materials out of the soil, or out of the atmosphere, and to use them as food. Until they have been worked up by plants, and made ready, we simply cannot use them. We depend entirely on the Vegetable Kingdom to prepare them for us.

\section{IV-The Food THAT WE EAT}

Let us think of some of the different things that we commonly take at breakfast or dinner, and try to find at least one or two that have not been made ready for our use by any plant.

Somebody may suggest, "Salt!" And we do get that out of the sea or from rocks in the earth, ready made. But though salt is good, we can hardly call it "food." No one could live on salt for even a very short time.

What about Bread? That comes from Corn. The raw materials, gathered out of earth and air by millions and billions of Wheat-plants, are worked up by each one separately into nourishing grains; and these are ground to fine flour, and the flour is made into loaves 
of bread. But if the Wheat-plants failed to do their part, we might cry out in vain for bread.

What about Butter? That comes from the milk of cows, churned into butter by man. And cows feed largely on grass and hay; either green grass, each blade of which has worked up the raw materials from earth and air into a form which cows can digest; or hay, which is simply dried grass.

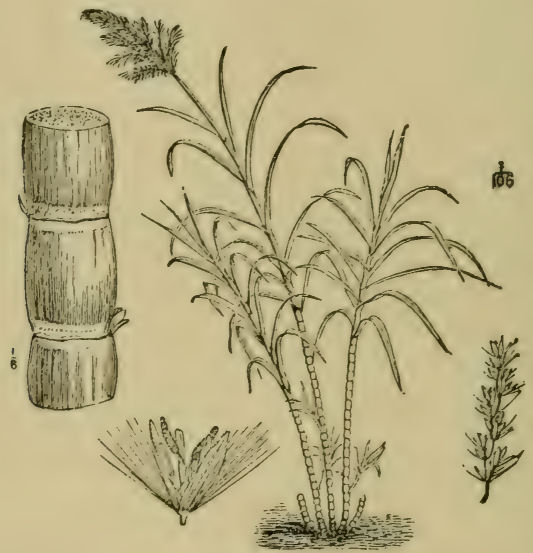

SUGAR-CANE.

What about Beef and Mutton? Just the same. Cattle and sheep live mainly on grass. Without it they would die, unless some other vegetable-food should take its place.

What about Cheese? That, again, is made from milk or cream. Without the right vegetable-food for cows we should have no milk, no cream, no cheese.

What about Sugar? Immense supplies of it come 


\section{THE POWER OF SUNLIGHT}

from a kind of grass, the Sugar-cane, which grows to a height of from eight to fifteen feet, with thick jointed stalks. In these stalks the sugar ripens, being manu-

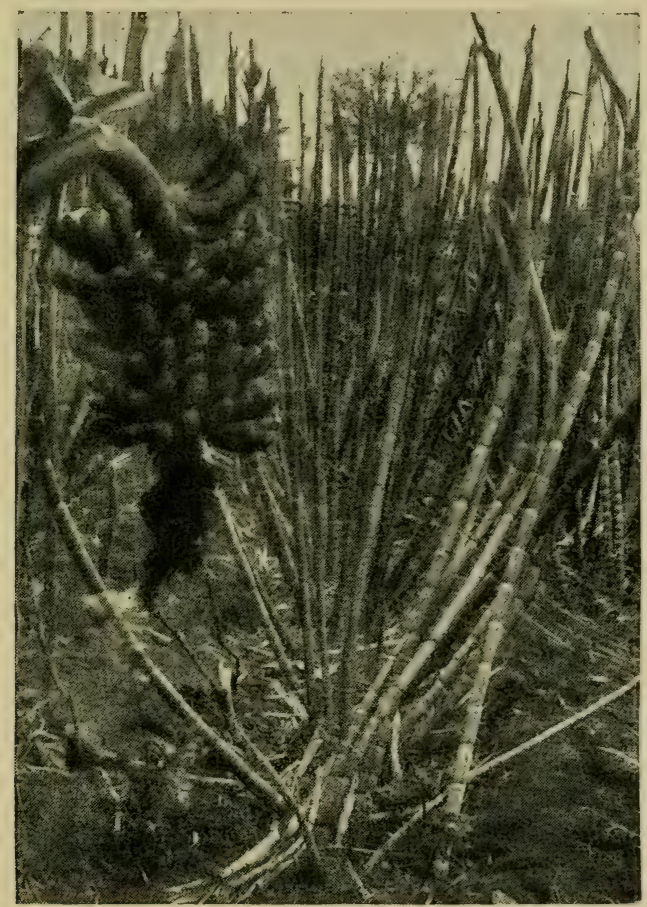

[Photo: J. da Luxe Perestrella.

BANANAS AND THE SUGAR-CANE ON CANARY ISLES.

factured there by the plants themselves. A large amount also is made from "Sugar-beet " plants, nearly related to Beetroot; and we all know what a sweet vegetable beetroot is, 
What about Rice? One of the most important of foods; not so much in Europe as in Eastern lands. The Rice-plant, like the Sugar-cane, is a kind of Grass; and it grows in water, and only in very hot countries, such as India. Its work is to manufacture those small grains, which we know well in puddings. Enormous supplies of Rice are needed; for it is the principal food of the people of India, China, and elsewhere. It has been said that more than half of the people in the world are fed mainly on Rice. And each tiny grain, of all

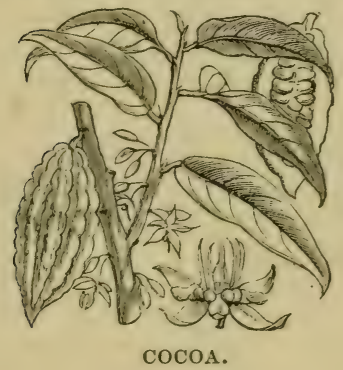
these enormous quantities, is made and shaped separately by the Rice-plant.

What about Tea? It also is grown largely in India and in China. Two or three hundred years ago tea was a luxury, used only by the very rich. Now everybody, even the poorest, must have his or her cup of tea. And it comes to us entirely through the work of leaves. In fact, as we know, tea is leaves.

What about Cocoa? The Cocoa or Cacao plant grows in warm countries, especially in Ceylon and the West Indies. It has clusters of small flowers, growing straight from the trunk, or from the larger branches, not from twigs or stalks. When the fruit ripens, a large pod, several inches long, hangs where the flowers were; and this pod holds rows of seeds or "cocoa-beans."

What about Fruits? Apples from the Apple-tree; pears from the Pear-tree; oranges from the Orangetree; dates from the Date-palm; bananas from the 
Banana-plant; strawberries from the Strawberryplant; currants from the Currant-bush; plums from the Plum-tree; peaches from the Peach-tree;-but the names are endless. All these and many many more are the work of the Vegetable Kingdom.

Then, too, the vegetables that we eat-potatoes, cauliflowers, turnips, carrots, cabbages, beans, peas, asparagus, onions - are numberless, and each one is manufactured by its own kind of plant, and by no other.

Nor is this all. When we turn to clothing, we find the same thing over again.

What about Cotton? Huge supplies of cotton are used by mankind, woven into all sorts of materials. Where does the cotton come from? Why, from the Cotton-plant, which grows abundantly in the plains of India and in other sultry

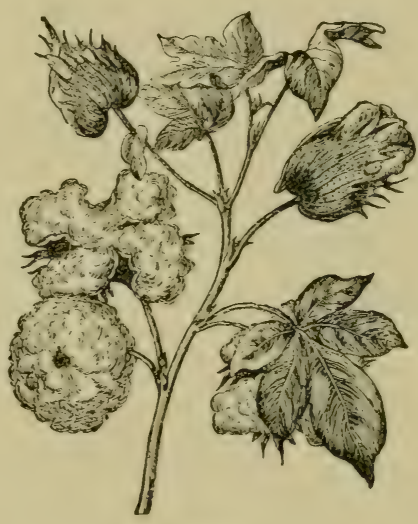

COTTON. regions. The cotton itself is a sort of soft down or fine hair, clinging to the seeds when they ripen.

What about Wool? We make from it all kinds of warm stuffs for winter wear; cloth, flannel, merino, also blankets and shawls, coats and comforting wraps of every description. The raw wool comes to us from the backs of sheep; and those sheep have fed on vegetable food. But for that food, but for the work of each small, grass-blade, the wool would never have grown. 
What about Silk? It is woven by the Silkworm, which feeds entirely on green leaves. What about Linen? It comes from the Flax-plant. And the list might be widened to any extent in other directions. What about Bass for the use of gardeners? It is procured from the Lime-tree. What about Camphor? It is distilled from the wood of the Camphor-tree.

So we see, just a little, what an immense debt we owe to the manufacturing work of plants. And I have not named a hundredth part of the whole; no, nor a thousandth part.

Not all useful to us, you may say. Very likely not. Man is not the only being on Earth to be considered. Certain growths, which are useless for ourselves, may have other uses, not known to us. At the least, when they die they help to enrich the soil.

And some which we might hastily condemn, counting them worse than useless, are not really so. There are plants which manufacture berries full of deadly poison; and if a child eats one or two of those berries, he will die. Yet that same poison, given in very tiny quantities at the right time and in the right manner, to some one who is dangerously ill, will act as a powerful medicine, and may save his life.

\section{V-OCEAN FOOD}

One thing more. How about Fishes, Crabs, Lobsters, Shrimps? Do we here owe anything to our vegetable friends?

Yes, a great deal; though we cannot speak in quite such certain terms with regard to ocean-creatures as with regard to land-animals. Ocean-life is so enormous, 
so different from life on land, that we are only beginning to understand a little about it.

So far as we know, however, the creatures there also which belong to the Animal Kingdom are not able, generally, to get their food straight from air or water or soil. They too must-generally-wait until it has been worked up for them by beings that belong to the Vegetable Kingdom. Only we cannot venture to say that with them it is always so.

You may smile at the idea of a fish having to do with air or with soil. But there is air in the sea, or a fish could not breathe. And there are soils at the bottom of the ocean, where hordes of animals live; many and curious kinds of soil.

On dry land animals feed largely on vegetables. But in the sea very few fishes feed on seaweeds. Just a small number do; while by far the greater number live entirely on animal-food.

The strong devour those that are weaker; and the weaker prey on those that are weaker still. So, stage by stage, we get down from the larger inhabitants of the ocean to those that are known as the "lower animals" of that vast region. Numberless hordes of small live things throng the middle and upper reaches; many of them of the Crayfish kind; very many only the young of bigger creatures dwelling below. And these serve as food for teeming millions of fishes; perhaps especially for such as herrings, which again nourish the larger kinds.

And on what do these "lower animals" feed-these multitudes of little restless beings? Do they depend on vegetable growths? 
Not on such seaweeds as we all know. But the whole ocean, down to a certain depth, is thronged with immense supplies of another kind of vegetable-tiny tiny specks of life, which were spoken about earlicr in this book.

Do you remember the Diatoms, and their minute ornamented shells? Small as they are, and invisible to our eyes, they yet are true plants, real vegetables. Being plants, they can only live where some amount of sunlight is able to reach them. Deep below, where utter darkness reigns, they cannot exist. But in the upper reaches of the ocean they throng in hundreds of billions, serving as food for untold myriads of animals, both small and great.

It has been curiously said in a recent work that: "Diatoms are the pastures of the seas;" 1 that, in fact, they take that place in ocean life which is taken on land by "the grass of the fields." And not Diatoms only, but many other kinds of tiny one-celled plantlets help to crowd the ocean.

But how about lower depths still, the floor of the deep, where all is darkness? Diatoms cannot live there; yet sea-creatures flourish.

As Diatoms die, their little bodies in tiny shells sink by millions to the bottom, and there form a fine "ooze" or mud. And the creatures that live on and near to ocean's floor are believed to swallow quantities of this muddy ooze, which is largely made up of Diatom remains. So in this way they also may come in for vegetable food.

Only-once more-we cannot say with the sea, as ${ }_{1}$ Conditions of Life in the Sea, by J. Johnstone, p. 77. 
with the land, that it is always thus. Some odd creatures are known to exist there-animals-which seem to have the power to prepare food for themselves, just like plants, out of the "raw materials." And they actually have in their bodies some of those curious little green particles, which on land are found in plants alone.

Other such instances may in time become known to us also. But on the whole, in the sea as well as on land, men and animals owe a heavy debt to plant-life. 


\section{PART VIII}

\section{THE WORK OF FLOWERS}

\section{I-What Flowers are for}

Now at last we come to Flowers, and to their work in life. All that we have heard so far about Roots and Stems and Leaves leads up to those lovely blooms, which are-at least in our eyes-the crowning part of the strueture. Not that they can be looked upon as its highest aim; for it is they who have to work out that aim; it is they who have to bring about the chief end and object of the plant's being.

We love them for their beauty, their wonderful forms, their colouring, their delicacy, their tenderness, their grace, their perfumes. They seem to belong to us; to be what S. Francis of Assisi would have called "Our little Sisters."

Great as is the variety found in kinds and sizes and shapes of leaves, the variety in flowers is even more astonishing.

They range in size from some so tiny as to be almost invisible, to others which are enormous. Some of these huge specimens are never to be seen in Britain; a fact that need not trouble us, for the largest are by no means always the most beautiful.

In the tropical parts of America grows a plant ${ }^{1}$

\section{An Aristolochia.}




\section{THE WORK OF FLOWERS}

which bears balloon-like flowers, so big that children sometimes draw them over their heads, for fun, like caps.

But the one which carries away the palm for size is a "Rafflesia" 1 found in the island of Sumatra.

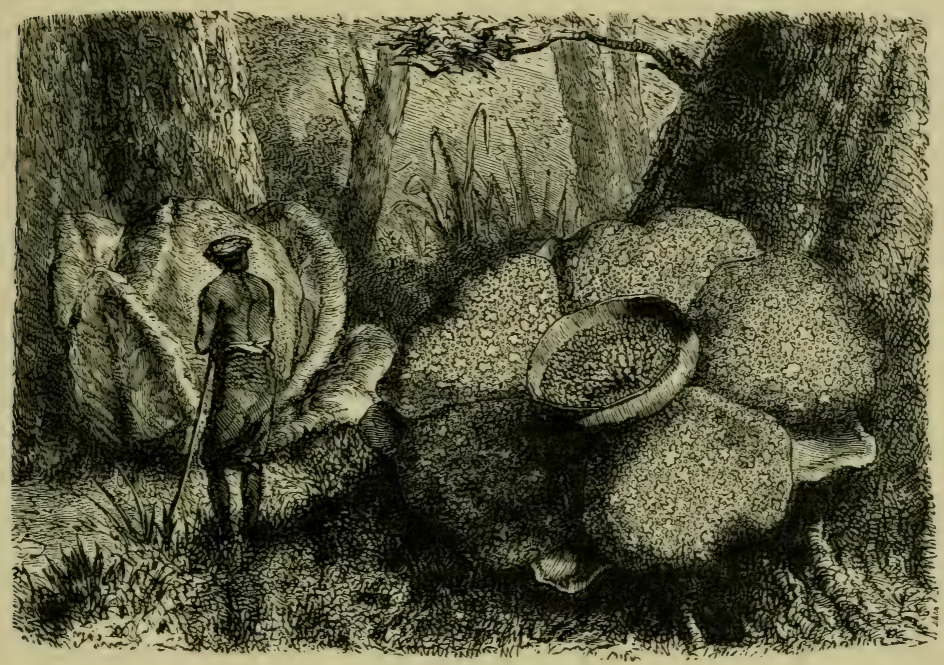

RAFFLESIA FLOWER.

This plant is a parasite; it does not draw its nourishment from the soil, but sends its roots into the trailing stem of a vine, and feeds on it. Living upon another is not a fine manner of life; and we all speak with contempt of "parasites."

The flower blooms close down on the Vine-stem, with no stalk. It is very thick and fleshy; and is said to 1 Rafflesia Arnoldi. 
be in shape not unlike an enormous Forget-me-not blossom. When fully open it measures three feet across. It has a most disagreeable smell; and we should hardly care to have one in our rooms.

One day, when walking on the Surrey Downs, I caught sight of a minute floweret at my feet, growing low in the grass. Plucking it, I had a good look through a magnifying-glass; and in a moment the wee thing, so tiny and insignificant, had changed into an exquisite flower, delicate and lovely, with pure white petals, beautifully marked, just like some grand hothouse bloom.

It is strange what shoals of lovely things are all around us in Nature, which we do not notice; which indeed often we cannot see without help from a microscope. And yet, no matter how small or how hidden away such things may be, their make and their finish are perfect. Nothing in Nature is ever "scamped" or done anyhow in a hurry, because " nobody will see!"

Between these two extremes among flowers, the very big and the very little, lie immense numbers of kinds, far beyond our power to reckon.

If we began only to talk of their shapes, their colours, their markings, we might go on for hours. And then their scents! Not all sweet, certainly. But many are delightful-such as those of Roses, Carnations, Violets, Lilacs, Heliotropes, Jessamines, Mignonettes, Lilies-ofthe-Valley.

At least five hundred different scents are known, one and all manufactured in little Plant-workshops.

It seems clear that Flowers are meant to be a joy to 


\section{THE WORK OF FLOWERS}

us. Though it is by no means only for admiration that they exist, since they like the leaves have an especial work to carry out-still they might have done that work without being so beautiful as they are. Many flowers which are not beautiful do the same work as their fairer sisters, and do it well.

But what a different world this would be, if we had no sweet little "Sister-blooms" to love and tend; if we had all that we need in the way of food and clothing through the Vegetable Kingdom, but nothing to satisfy the craving that is in our minds for beauty of form and of colouring.

"There in a meadow, by the river's side,

A flock of nymphs I chancèd to espy,

All lovely daughters of the flood thereby,

With goodly greenish locks all loose untied

As each had been a bride;

And each one had a little wicker basket

Made of fine twigs, entrailèd curiously.

In which they gather'd flowers to fill their flasket,

And with fine fingers cropt full feateously

The tender stalks on high.

Of every sort which in that meadow grew

They gathered some-the violet, pallid blue,

The little daisy that at evening closes,

The virgin lily and the primrose true,

With store of vermeil roses,

To deck their bridegrooms' posies

Against the bridal day, which was not long;

Sweet Thames; run softly, till I end my song." 1

\section{II-Pistils and Stamens}

In an earlier chapter we heard about the different Parts of a Flower. They were : the Flower-stalk; the

1 E. Spenser. 
Calix or Sepals; the Corolla or Petals; the Stamens, with their Pollen; and the Pistils.

Stamens are usually in two parts; the Filament and the Anther. The word "filament" is from the Latin for "thread"; and the filaments or stamen-stalks are often so fine and delicate as to be very much like threads.

But the really important part of a stamen is the anther; precisely as the really important part of a leaf is the blade. A leaf is still a leaf, though it has no footstalk and no stipules. And a stamen is still a stamen, though it has no filament. But a footstalk without any blade would not be a leaf; and a filament without any anther would not be a stamen.

Inside the Anther is the Pollen; and without this curious golden dust the flower could not do its work.

A Pistil, like a stamen, has more parts than one; generally three-the Stigma, the Style, and the Ovary. Some plants have only one pistil to each flower; others have two or many pistils; but each pistil may have these three parts.

By the style is meant the little stalk. The stigma is on that stalk; and the ovary is down at the bottom of it, often embedded within the flower, out of sight. That small hollow ovary is one of the necessary parts of the whole. It and the stigma are as important as the stamen-anther.

Sometimes a pistil has no style; and that does not matter. What does matter is that there must be stamens and pistil. Without these two the flower-nay, the plant itself-would be a failure. They need not, however, be always on the same flower. The pistil may 
grow on one flower, and the stamen on another. But both are needed.

Sepals and petals have their task to do, in sheltering and protecting the stamens and the pistils. Yet without either sepals or petals the flower might still be a flower.

And why?

Because the true work of a flower, that for which it lives, is-not merely to be beautiful, not merely to give forth a sweet scent, not merely to win admiration, butto bring forth fresh life, to start new plants, which in time may take the place of the old ones which die.

Seeds, it is true, are not the only mode by which plant-life can be carried on. A gardener is able to produce new plants by other means. A slip from a Rosetree, cut in a certain way and put in soil of the right kind and carefully tended, will send out roots and in time will become a Rose-tree. Or a leaf-bud may be taken and put into the stem or branch of another kindred tree, and it will grow there, sending forth a shoot, and in time bearing roses like those of the tree from which it was taken.

Such modes are called "growth by cuttings" and "budding"; and "grafting" is another plan, not unlike the last.

But these are and must be the work of a gardener. No plants can carry out such methods for themselves. In a wild state their only way of bringing fresh plants into existence is, generally, by seeding. So the manufacture of seeds really is the prime work of flowers. It is that for which they are made, and that for which they die. 
Yes; they not only live for it, but also they die for it. Until the flower fades and falls, the seed has no hope of beginning its life as a new plant.

You may remember what Keble wrote, on the subject of the work of flowers, when describing a day in early November-

"Why blowest thou not, thou wintry wind,

Now every leaf is brown and sere, And idly droops, to thee resigned,

The chaplet of the year?

"Now quiet shows the woodland scene;

Each Flower and Tree, its duty done,

Reposing in decay serene,

Like weary men, when age is run."

So each tree, each leaf, each flower, may be looked upon as just doing its duty.

\section{III-How the SEeds GRow}

Inside the small ovary of the pistil are tiny bodies, called Ovules; sometimes many, sometimes only one or two. And since it is they that are meant to grow into seeds, the question of new young plants depends on them.

The word "ovule" means "little egg"; and an ovule is, in a sense, as much the beginning of a future plant as a bird's egg is the beginning of a future young bird. The ovary is a kind of case which holds the ovules.

Each of these has to begin life as a single small cell, with its lining of living substance. That cell has power to grow other cells; and when they are formed, the one 
divides into two, and each of those two again into two more. As the numbers thus increase, they remain firmly pressed together, gradually taking shape as a tiny living ovule.

Next, the ovule has to grow into a seed. But the pistil cannot manage the whole of this work alone. It must have help.

True, it has help already. There is the eager Life of
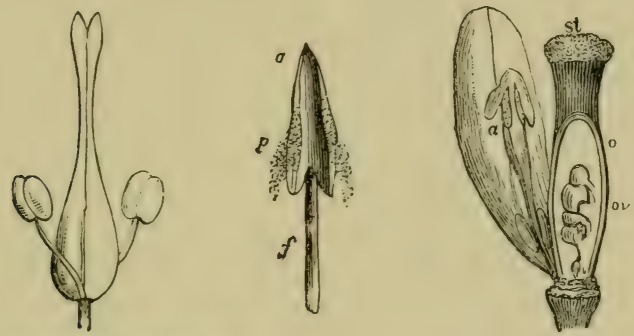

FLOWER OF THE COMIMON ASH.

A STAMEN OF THE WALLFLOWER : $f$, filament; $a$, anther; $p$, pollen. VERTICAL SECTION OF THE OVARY OF THE BARBERRY : $o$, ovary; $o v$, ovules attached to a projection called the placenta ; st, stigma ; $a$, anther.

the Plant. There are the air and water and food, taken into roots and stems, and worked into condition by the green leaves. There is the great sun, shining down by day, and giving that warmth without which no seed could ever come into being.

Yet these are not enough. Something else must happen, if the ovule is ever to become a real seed; a seed which shall have in it, not only life, but exactly that kind of life which may grow later into the same kind of plant as the one in which the seed itself grew. Sunshine, and water, and air, and food, and the 
prepared sap passing through the plant-all these must fail, unless a certain something takes place.

A little of the golden pollen from one of the stamenanthers must somehow reach the stigma of the pistil, and must send a slender tube-like growth down the style or stalk, to reach and touch the ovule below.

And then, from this meeting, this union, of a pollengrain with an ovule, a seed is formed; and in time, under right conditions, a new young plant-child of the old plant-may be expected to spring from it.

It might at first sight seem rather curious that, while this union of the two is so vitally needful, all sorts of difficulties seem to be put in the way of its coming about.

Matters would be so easy, if only the stamens of a flower were always nicely arranged just around and over the pistil of that flower. Then, when the pollen is ripe and the ovules below are ready for it, and the anthers are opening, a passing breeze and the swaying of the plant would shake down some of the loosening golden dust upon the pistil-tip, exactly where it is wanted.

But that is by no means what usually happens.

Perhaps the pistil grows very tall, standing up and away from the stamen-tips. And when the pollen falls, it drops down below, wide of the stigmas, and is blown away by the wind.

Or the stamens themselves grow long, leaving behind the short pistil-tips, and the plant droops over on one side; and again, when the pollen escapes it does not touch the pistil.

Sometimes a plant has two kinds of flowers growing 
on it; one kind having stamens only, and no pistils; the other kind having pistils only, and no stamens. This is the case with Pines; and with them the pistilflowers grow high up, the stamen-flowers low down. So the pollen as it falls, is likely to be borne away by the breeze, and none of it may reach the pistils above.

When, as often is the case, the stamen-flowers grow on one tree, and the pistil-flowers on another tree, the difficulty becomes still greater.

Yet all this is only perplexing until we find the true reason for it. A right good reason exists.

The main object throughout is clearly that pollen should reach the pistils. But-not the plant's oron pistils. That makes all the difference.

For the sake of the plant itself; for the vigour of the seed; for, if I may say so, the growth of character in the plant-race-we know it to be better that a plant should not use its own pollen, but should receive some from another plant of the same kind. And who may assert with authority that "character" is not a thing aimed at in the life of plants, even as in a far greater and higher degree it is aimed at in the life of human beings? True, in their case it is perhaps character rather of the type than of the individual. Yet even with them there is individuality; since no two plants of the same kind and under the same conditions ever grow precisely alike, or respond in precisely the same mode to their surroundings and their opportunities.

Therefore, deliberately and purposefully, and not by chance, all kinds of difficulties are put in the way of a plant using its own pollen; so that, for its own good, it is driven to seek some from elsewhere. 
And since it is tied to one spot, and cannot possibly travel for what it needs, it is compelled to make use of other means. How this is done will come later.

Many years ago the Variegated Laurel was introduced into our country from Japan; but only the pistilbearing kind came. So none of the bright red berries, admired by travellers, were seen here. After a while the other and stamen-bearing kind was brought too; and speedily red berries made their appearance all over England. This illustrates the absolute necessity for pollen, before the pistils can produce seeds.

\section{IV-Plant Storage}

As the young seed grows it needs food; and the parent-plant has to sce that the hungry young ovules and seeds are properly supplied. Shut up as they are inside the ovary, unable to get out, they can do nothing for themselves. So the roots and leaves must keep them going.

Three different kinds of plants are commonly known : those which live one year only and then die, called Annuals; those which live two years and then die, called Biennials; and lastly those which live many years, called Perennials.

The two first are alike in a single respect, that they flower only once. But the one-year kinds have a much shorter time in which to complete their task; so they are obliged to " hurry up" with it.

All that they have to do must be done in one seasonthe growth of the plant itself from a seed; the forming of roots, of stems, of leaves, of flowers, of seeds. The roots have to gather in food; and the leaves have to 
prepare it; and the finished sap has to make its way through cells and channels to every part, that the tiny beginnings of seeds may get their full share. And at the end of the summer the plant dies, quite worn out. But the seeds remain alive, ready for the next spring.

Two-year plants manage differently. In their first season they grow roots and short stems and leaves, but no flowers. They are indeed much too busy, laying in stores, to have any leisure for flowering. Thus far, their work is one of preparation. They are gathering together a supply of nutriment, ready for use in the year following; food for the flowers, food for the seeds.

With some plants much of this food is piled together in the roots, as with a Radish; the long red root of which we all know so well. But the plant did not mean it for you ! It meant that nice little reserve-store for its own use next year-if we may say that a plant in any sense " means" anything-and you have spoilt those plans, by stealing the deposit.

When nobody interferes and the plant is left to its own devices, it goes on with its preparations through the first summer. And when the following spring arrives, it begins to bud and flower. Then the root slowly shrinks and gets thinner, as its carefully husbanded provision is used for present needs.

With many plants the bulb may be said to take the place of a seed; as in the case of Crocus bulbs, Snowdrop bulbs, Hyacinth bulbs and others, which begin life with only one small seed-leaf. These bulbs also are packed full of hidden provender, enclosing the little bud from which the new plant will spring. And as the young plant 
grows, the bulb will gradually give up its stored supply, becoming smaller and smaller.

Sometimes the storage is in the leaves, instead of in roots or bulbs. We find this with a very commonplace though useful plant-the Cabbage. You know what large strong leaves it has, and how wholesome they are

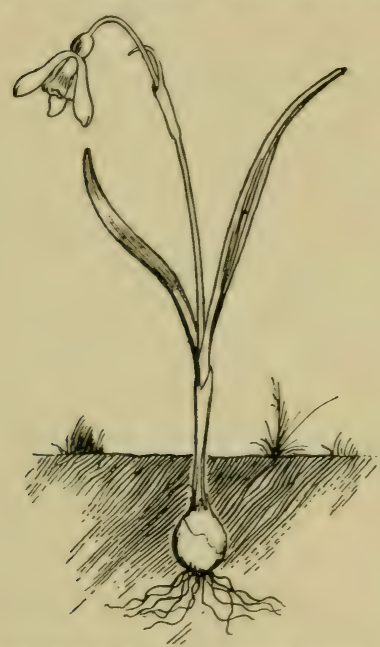

SNOWDROP. (Showing stem, flower and root.) said to be. No wonder!-for the leaves are real reservestores of food, laid by for the plant's own use.

In other cases, again, the storage is in the stem, instead of roots or leaves, as with the brown "tubers" of the potatoplant. Many people suppose them to be roots, because they are dug out of the earth. But they are really more in the nature of swelled portions of underground stems, as they have buds-the "eyes." They are big with a fine hoard of starchy nourishment, which would later have been most useful for the plant itself, if some one had not stepped in and eaten the "potato."

These storages are found, not only in biennials, but in plants of longer life. And there are also special little stores, carefully put by for the feeding of the seeds when they begin to grow.

By that time the seed will have separated itself from the parent-plant, which may or may not have died. But 
the living seed has its own little private store, packed neatly inside its hard outer coat.

Sometimes the stock of food is in the "cotyledons," and usually it is folded close about the tiny beginning of life in the seed. Either way it is at hand, ready for use, so soon as it may be wanted.

"Fair Daffodils, we weep to see

You haste away so soon;

As yet the early rising sun

Has not attained his noon.

Stay, stay,

Until the hasting day

Has run

But to the Evensong;

And having prayed together, we

Will go with you along.

"We have short time to stay as you,

We have as short a spring,

As quick a breath to meet decay

As you or any thing;

We die

As your hours do, and dry Away,

Like to the summer's rain,

Or as the pearls of morning dew

Ne'er to be found again." 1

\section{V-Making Ready for Summer}

Even in the cold dark days of winter, when growth is more or less at a standstill, when the plant is in a kind of chrysalis state, when nothing seems doing, even then we must not suppose that the seed is perfectly idle.

Inside that hard outer coat, preparation is going on. Through the winter months the seed is living, breathing,

${ }_{1}$ Robert Herrick (about A.D. 1600). 
getting into the right condition. Changes are taking place in its make, without which it would be unable later to carry out its appointed task.

This silent winter-work of seeds, of bulbs, of plants in general, is very wonderful. All outside looks dead and lifeless. No one would imagine how much activity lies beneath.

Some plants are more asleep-more like a chrysalis, in fact-than others. We know how all but lifeless a chrysalis may seem; yet it is not dead. It is only preparing for a happier future. And in the same manner the trees are not dead; the bulbs and seeds are not dead.

Many among them are already at work, very quietly, very noiselessly, yet not less truly. Down in the dark earth with some, inside the dead-looking boughs with others, leaf-buds and even flower-buds are being manufactured, are being shaped and put together, in readiness to burst out joyously when the right hour shall arrive.

By some people winter is counted a rather sad season. Not by girls and boys who do not mind cold, who can race and slide and skate. But for older people, and for lovers of gardens, it does perhaps seem rather melancholy.

Yet it is not really so. It is only Nature's night; and night is needful for those who work hard. Winter is Nature's time for rest in her Vegetable Kingdom, and for gaining fresh strength to work anew. The world around may look grey and dull and chilly; but actually it is full of hidden life, full of hope, full of growing readiness for the lovely time coming. 
Bulbs look very dead when taken out of the ground, and placed upon a shelf, or put back into the earth. Either way they have to wait, silently and patiently. To wait for what? Why-for the coming of the Sun in his power, that he may call them to a new life.

Meanwhile, though buried, they still live. They are being made ready for the presence of the Sun. They are growing, under ground, their new and glorious spring garments. When spring is here, they will be ready to respond; ready to say to the Sun : "Yes, here I am -waiting!" ready to send forth new roots, new stems, new leaves, new flowers.

This work of preparation, which goes on under ground or above ground, with seeds and bulbs and branches, takes time. Certain alterations, certain developments, inside the seed or bulb or branch, have to come about before the new growth can begin to show itself.

It was at one time thought that bulbs and seeds might start growing much earlier than they do, if only they were in the right soil, and had the right amount of warmth and moisture. It was supposed that they waited for the spring, only because of the checking cold of winter.

But this, with the greater number, was found to be a mistake. The experiment was tried; and they did not respond. They would not begin growing until the spring.

Much the same was noted with potatoes. Some potato-tubers were dug up in the autumn, and were put in a warm sheltered cellar, where the air remained always at about the same degree of warmth. For many 
months, through mild autumn days and cold days following, they lay there quietly; doing nothing that could be scen. Then spring eame. In that sheltered cellar no sunshine could enter; and the air was found to be actually colder than it had been through the winter. Yet, strange to say, those tubers began to sprout, began to send out slender shoots, bearing leaves.

Now why and how was this? If they grew then, when there was no added warmth to make them, why should they not have begun earlier?

Simply because they were not ready! They needed the winter months for all that had to be done first; for the changes that had to go on in them, before such growth could become possible. Warmth at the right time would help them. But warmth before they were ready to sprout was useless. They had to get through their preparatory work; and then-and not till then-could they carry out those tasks in life, which would be their duty to do.

It is the same with hundreds of plants, which scatter their seeds on the ground in autumn days.

There the seeds lie, to be gradually washed into the soil, where they often find at once plenty of warmth and moisture; quite enough, one would think, to make them "germinate" without delay. Yet they do not. They send no roots downward, no leaves and stems upward. They lie hidden; making ready for their future.

And perhaps a cold spring comes, much colder than the autumn was. Such cold must and does hinder advance. Yet, in spite of it, many seeds and bulbs start active life, though slowly, and begin to send forth leaves, sometimes even flowers. For now they are 
ready; they have had their time of preparation; and that makes all the difference.

In this, as in other respects, plants vary greatly. Some seeds take much longer than others in preparing. Some are more readily affected by warmth. Some will spring up at almost any time, like Mustard and Cress, under certain conditions. And the above is true of bulbs, as well as of seeds.

Spring is really a time of Resurrection.

Each bare and lifeless tree, which in the autumn "seemed to have died," 1 has only been asleep; and now, with the coming of spring sunshine, it leaps into a new and glorious life. Each bulb which "seemed to have died " and was buried in the earth, forces its flowers upward to a fresh and lovely existence. Each little seed, which looked so cold and lifeless, is found in some new form of beauty and fragrance, while still remaining itself. The individuality is unchanged. If that seed had never been sown, that plant would never have grown.

Nature holds for us many symbols, many parables, if only we will read them, as surely we are meant to do; and none more striking than this. Perhaps the most wonderful part of it is that, while so buried, while still so seemingly " dead," the bulbs and the seeds are actually at work, fashioning their own resurrection bodies in readiness for the coming springtide. May we not find here a suggestion, if not an actual prophecy, full of promise for our own future, and for the future of those who still belong to us, though out of sight-who are "not lost, but gone before" ?

${ }^{1}$ Wisdom of Solomon, iii. 2. 


\section{VI-SeEd-Scattering}

A few words must come in here about another part of the matter; and that is - the way in which seeds are scattered about and carried from place to place.

It is easy to see that if the plant-any plant-had

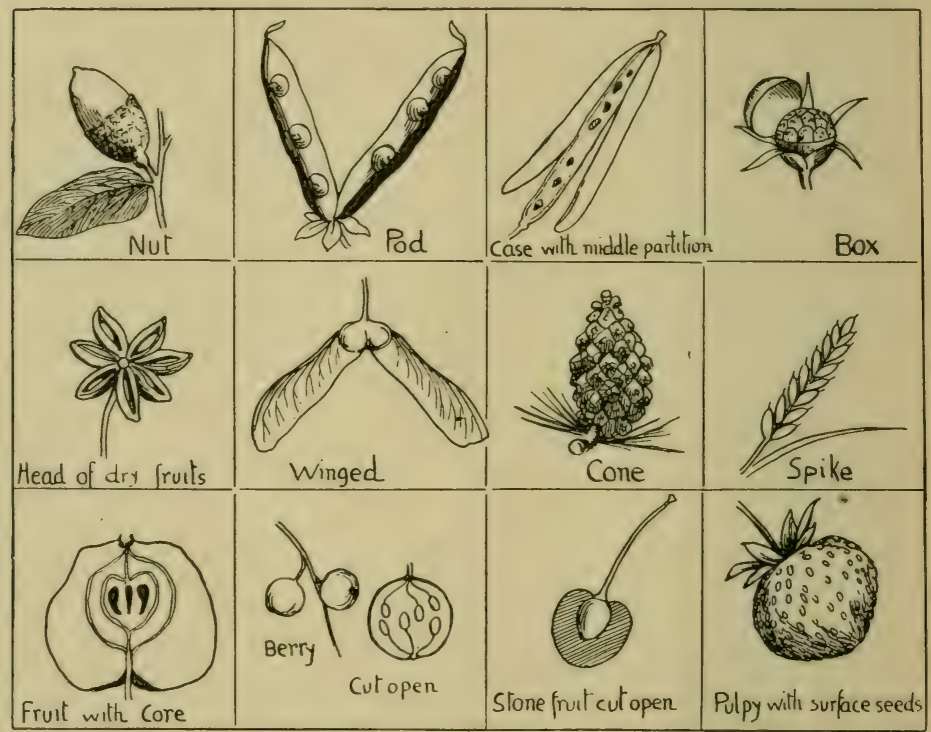

VARIETIES OF FRUIT.

to manage this work alone and unaided, failure might commonly result. The seed, on becoming ripe, would just fall from the flowers to the ground, close at hand. How could they do otherwise? Then, when the young plants grew, they would crowd round about the old plant, and would soon choke one another to death. 


\section{THE WORK OF FLOWERS}

Imagine what would happen, if all the acorns of a great Oak were to drop down within a few yards of the trunk, and all were to take root and grow up. Hundreds,

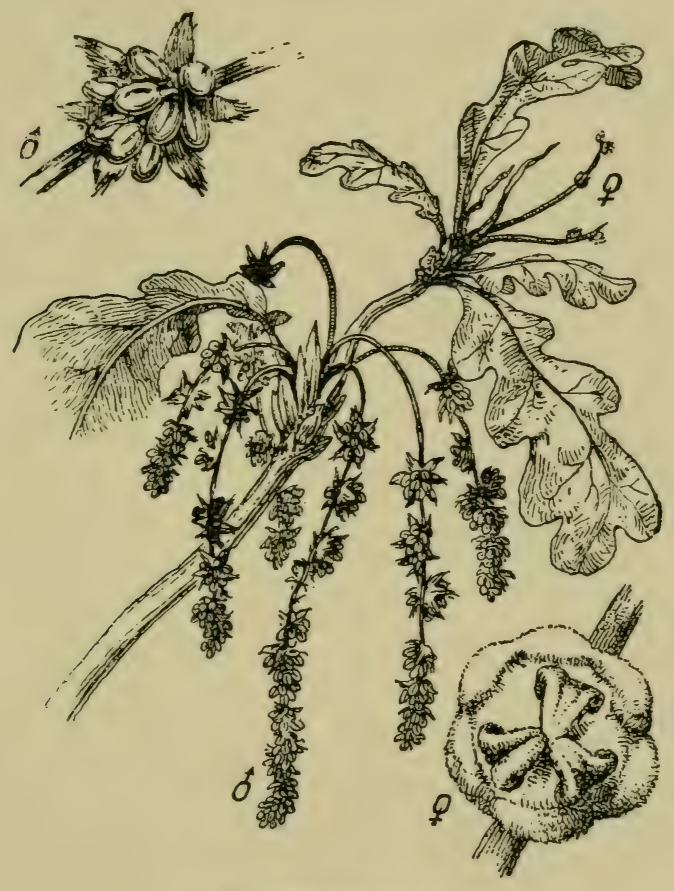

FLOWERS OF OAK.

of Male. \& Female.

if not thousands, of young Oaks might be fighting for life at one time, under the shadow of the parent-tree. And they could not thrive. Space and light and food would all be lacking. Fortunately, acorns do not so 
casily find a footing. But with many other plants "germination" is a quicker and more easy matter.

Thus the pressing need comes in that seeds should somehow travel or be taken elsewhere. And then arises the necessity for help from outside.

All do not need such help equally, since many plants

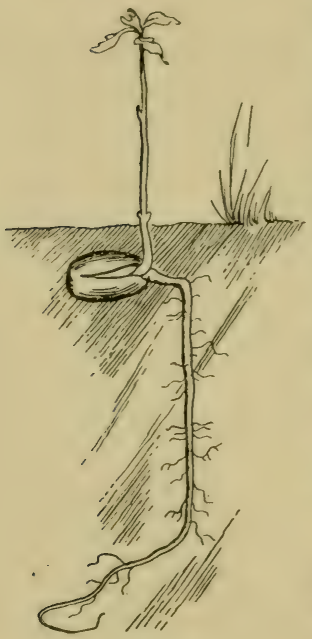

ACORN. can do a good deal for themselves. A large number come under the heading of "Sling-fruits"; a name used for those that possess a curious " expulsive force," by means of which they can sling or fling their seeds to a distance. With some, the seeds are jerked away; or they are shot off as from a catapult; or the enclosing envelope, when it breaks open, does so with an energy that tosses the contents violently to right and left.

Many plants, however, are gifted with no such clever mechanical devices, and they have to depend on outside assistance.

The winds of heaven step kindly in, and make themselves useful, especially with smaller and lighter seeds, easily carried about. Not a few are so formed as to float in the air; and one of these we all know-the Dandelion-seed, with its soft downy "attachment." Dandelion "clocks" as the children call them will rise high and fly fast before the gentlest breeze.

Seeds of this description may travel to almost any 
distance; and there are many others more or less like in kind. Some have light growths of hair, serving the same purpose; some have tails or wings or feathers; all making it possible to rise lightly and to journey far.

Water lends a hand in the work, though not so largely as wind. Naturally, the seeds of water-plants
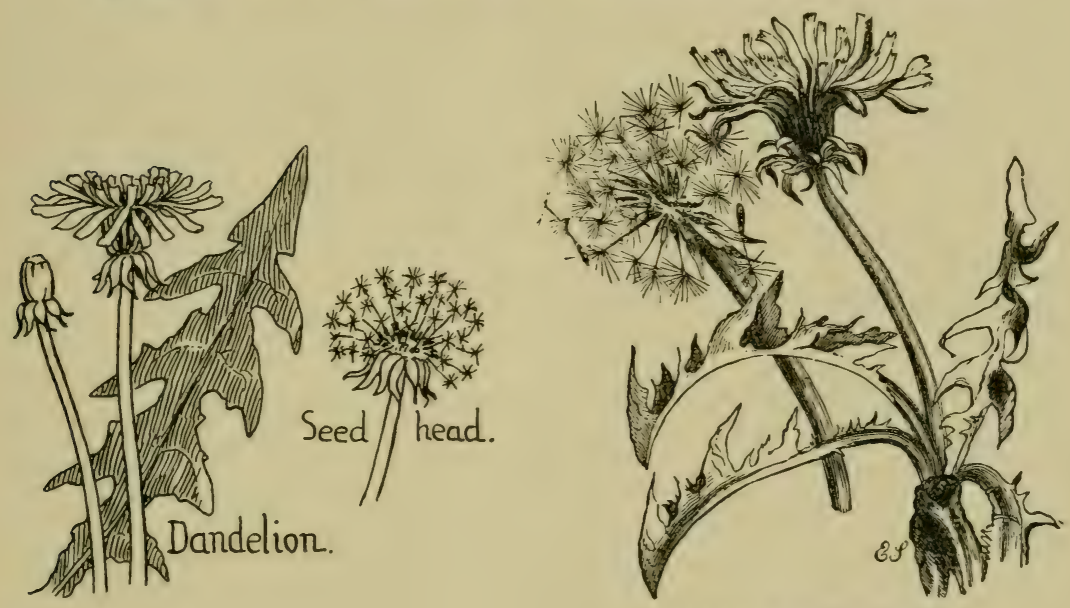

TARAXACUM OFFICINALE

(Common Dandelion).

are carried off by currents; and land-plants sometimes drop theirs into a river. Swept down towards or into the ocean, they may voyage to a distant shore, before finding a soil in which to root. But this can only happen with those which have an outer coat hard enough to keep the inside perfectly dry, from the beginning to the end of their excursions. Cocoa-nuts floating in the sea have been known to travel to far-away resting places. 
Animals also give some help. When sheep and cows and many smaller beasts press against bushes and hedges in autumn days, seeds are apt to cling fast to their hairy or woolly or furry coats, and to be carried to a good distance. Ducks, disporting themselves at the edge of a pond, and becoming half-clothed with mud, will bear away seeds in that mud, to deposit them elsewhere. Even birds flying-even some insects-give their aid in much the same fashion; one and all helping to scatter seeds broadcast. 


\section{PART IX}

\section{THE WORK OF WINDS AND INSECTS}

\section{I-Pollen to the Pistil}

SINCE anthers really are transformed leaves, and since pollen is manufactured in the anthers, these again may perhaps be called small workshops; different in kind from the green-leaf ones, yet not less important.

At one time pollen was often spoken of as "Flowerdust"; a pretty name! But with many plants, in place of being a fine powder, it was found to be sticky and in lumps, far too tiny lumps to be seen as such without a microscope.

When ripe and ready for use, the pollen has to make its escape; and this comes about in many ways. Frequently a tiny slit or hole appears first in each small sac; and the pollen-grains are no longer imprisoned. Yet even then, though the prison-door is actually open, they have no power to walk out; so they must wait for something else to happen, completing their release.

And here we touch on a very interesting matter; that of Cross-Fertilisation.

In an earlier chapter something was said about the difficulties put in the way of a plant supplying its own pistils with pollen "made on the premises,"-pollen from its own stamens; and about the need that it should 
not, for its good, for the sake of its health and vigour, be allowed to do this. It is in every way better that the pollen which reaches its pistils should come from some other plant of the same kind. If not from one of precisely the same variety, it must at least be a very near relative; otherwise the golden dust or sticky little lumps will be useless.

And just as plants, because they are fixed in one place and cannot possibly travel about, have to use outside help in scattering their ripened seeds, so at an earlier stage, they must from the same reason use outside help in exchanging their pollen, one with another.

We sometimes hear of what is called "Crossing" by gardeners. That is to say, the gardener takes pollen from one plant - from an Orchid, for instance-and puts it on the pistil of a second, not precisely the same in kind though closely connected. And from the union of these two may spring a third Orchid, partly like the one and partly like the other.

Cross-Fertilisation on the contrary is done, not like Crossing by gardeners but by the plants themselves, with outside help. Such help is commonly given by Winds, by Water, and by Insects.

A child may accidentally share in this important work, though it happens rarely. You may have seen a little boy thrust his nose into a Tiger-lily, with its gorgeous striped petals; and when he moves away-if it is the time of ripened pollen-he may have a yellow tip to his nose. Then if he should go to another Tiger-lily plant, and should put his nose into a second flower, he would prob-. ably leave a little of the yellow stuff there, on a pistil-tip. 


\section{THE WORK OF WINDS AND INSECTS 139}

So, unconsciously, he would have given his tiny help in the world-wide work of Cross-Fertilisation.

One of the chief friends of plants, as just stated, is Wind.

In some trees the catkins or stamen-flowers, with their stores of pollen, grow long and hang low; while the pistil-flowers, with their ovules, are perhaps higher up; so that the pollen from the former would not easily reach the latter. And the reason why it should be so we know: It is better for the trees that each should pass on its stores of golden dust to other trees, and should receive what is needed for its own use from those others. It is better, in fact, that each tree should not live a selfcentred and selfish life, merely to supply its own needs, but that all should "freely receive and freely give."

As their pollen is very light and dust-like, the most gentle of breezes can lift the whole supply above the tree-tops. Then, when it slowly descends, all the pistils have a fair chance of capturing enough for their requirements; while no tree is likely to receive pollen of its own manufacture, since that would soon have been borne away by the breeze.

Pollen-grains are very tiny; and the amount contained in each stamen is small; therefore naturally we do not realise what huge supplies are grown every year. In the majority of cases it quits the little enclosing sac in so gentle and unobtrusive a manner as to draw no attention.

But when a great number of trees of the same kind grow together, and when they all shed their "dust" at the same time, the effect is much more in evidence. 
For example, in a vast Pine forest, immense clouds of pollen may be seen, swept along by the wind, not only through the forest itself but far beyond, falling like a fine golden rain on trees and grasses. Of such abundant quantities only a few specks here and there may arrive on the waiting pistil-tips of kindred trees; few, that is

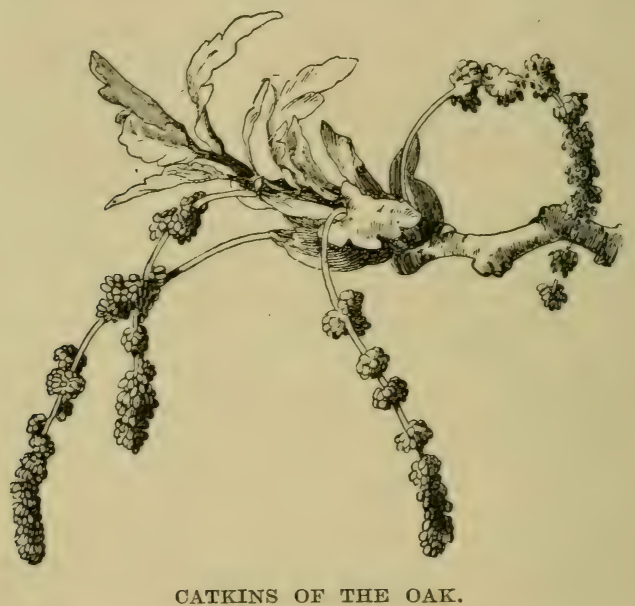

to say, compared with the tens of millions which drop where no pistil-tips are waiting. They sink to the ground, unwanted; useless failures, one might say. The matter may, however, be viewed from another standpoint.

Suppose that only just enough pollen were manufactured each year to meet the needs of all pistils, not allowing for failures. Much of it still would not reach the right spots; and this would mean many less seeds 


\section{THE WORK OF WINDS AND INSECTS 141}

brought to perfection, which in time could hardly fail to diminish sorely the numbers of our forest-trees. We usually find in Nature this wonderful fulness of supply; far more of each kind of growth than may seem to be

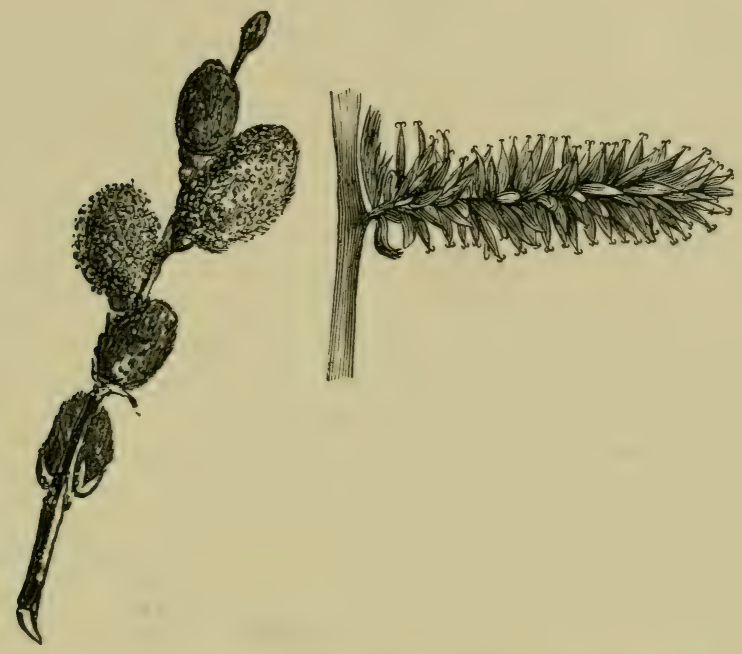

STAMINATE AND PISTILLATE CATKINS OF A WILLOW.

actually needed, so as to make sure that there will always be enough.

It means something else that is beautiful. It means that Our Father in Heaven gives with a Royal abundance. He gives like a King.

Large numbers of our trees depend almost though not quite entirely, for this work of scattering pollen, on the help that is given them by Wind. One curious instance 
is that of the Hazel-tree, the pollen of which is not ripe at the same time that the stigma is ready for it. So the pistils' only chance is the bringing of pollen from other Hazel-trees by friendly winds - from stamen-flowers which happen to have ripened a little earlier.

Oaks and Beeches, Poplars and Birches, Walnut-trees and Plane-trees, most of the Conebearing-trees and most of the Palms, have their pollen conveyed in this way from one to another, with very little other assistance. The same may be said of Grasses generally, of Rushes and Reeds, of Wheat and Oats and Barley. All these manuture pollen fine enough and dry enough to be carried with ease by moving air.

On a warm and fairly still evening in late summer, at a time when pollen is ripe, clouds of it may sometimes be seen floating over a meadow; the stigmas being then ripe to receive it. Each kind of grass must have its own particular kind of pollen; and when supplies are dealt out thus by the breeze in wholesale fashion, they naturally get a good deal of the wrong kinds. But this does not matter; for when the wrong kind is dropped on a stigma it simply takes no effect. Some of the right kind is pretty sure to find its way thither also.

Each passing breeze, as well as stronger winds, takes a share in the task; helping first to stir the flowers, thus loosening the imprisoned powder; and then carrying it where it is wanted. The number of different kinds of plants, thus regularly assisted by the winds, is said to be as much as ten thousand.

But Wind is only one of the kind friends which come to the help of plants. We have next to think about the doings of INSECTS. 


\section{THE WORK OF WINDS AND INSECTS 143}

"We were a million grasses on the hill,

A million herbs which bowed as the wind blew, Trembling in every fibre, never still;

Out of the summer earth sweet life we drew. Little blue-flowered grasses up the glen, Glad of the sun, what did we know of men?" 1

\section{II-How Doth the Busy BeE}

The story of Cross-Fertilisation, through generous offices of Bees and other Insects, reads curiously like a tale of friendly co-operation between them and Plants. Between Plants, earth-bound, fixed immovably in one spot for the term of their natural lives; and Insects, free to range hither and thither at will.

Plants require help in the work of supplying their pistils with the right pollen; and Insects require food for themselves and their young. So plants manufacture and offer tempting supplies of honey and pollen; while insects, creeping or flying in to secure that food, give the needed assistance by carrying pollen from one plant to another.

Books to any extent might be written, and in fact have been written, on that one topic alone. In this small volume no more can be attempted than to point out the general mode pursued, with a few slight instances given as examples of what goes on perpetually at floweringtime throughout the world. The subject is one well worth studying.

For, indeed, it is a marvellous story of mutual intercourse and mutual help; unconscious, we may say, on both sides; though that which is done often looks

1 From Lollingdon Downs, by John Masefield, published by William Heinemann. By permission. 
strangely-like many other things in insect-life and even in plant-life-as if both insects and plants knew in a manner, dimly, what they are about.

In any case, one fact becomes clear with daylight clearness, that all the vast work of Cross-Fertilisation is part of a great plan-a Divine plan-not, as once was imagined, putting needless hindrances in the way of success, but working steadily and systematically towards beautiful ends and ever fuller developments. The reading of it recalls to mind certain words spoken in earliest days of our world's history- "And God saw that it rwas good!"

That each helps the other is a truth undeniable. A plant cannot stir; but it can manufacture food. A bee can flit to and fro with ease, but it cannot manufacture the sweet stuff which forms the foundation for real honey. The raw material is in the flower; and the hive-bee has in its own little body a small apparatus which can transform that raw material into food for itself and for human kind.

So the plant does all it can to attract the bee-and other insects. And the bee does its utmost to satisfy its own needs, while performing friendly offices for the plant.

Most of us must often have watched a big humble-bee bustling from flower to flower; diving in and out of blossom after blossom; blundering into this one and that one in her eager search; till one is almost forced to the belief that bees are not quite so clever as one had imagined. She keeps forgetting which flower she has tried before, and she rushes again and again into the same, coming out with what sounds like a "buzz" of indigna- 


\section{THE WORK OF WINDS AND INSECTS 145}

tion at not finding what she expected. Whether all are equally dense it is difficult to say; but certainly I have at different times watehed several acting thus.

Sooner or later she generally meets with success. Then she remains for some seconds, gathering the nectar that she loves. And while so occupied, something else

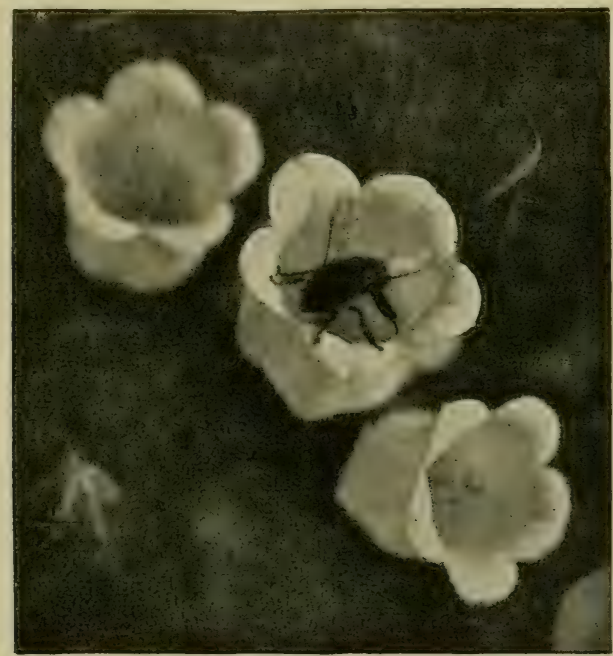

POLLINATION BY BEE.

is apt to happen. If the pollen is ripe, part of it sticks to her legs, and probably to her body as well. This she carries away to the next flower into which she plunges; and as she buzzes and squirms about, a little of it is rubbed off, to remain on the pistil or pistils of the second flower.

Such is the mode in which bees and numberless insects carry on the work which winds undertake with grasses. 
They, too, are helping forward "fertilisation," not knowing or caring about that object, any more than do the winds, but intent only on getting their food.

Through all the warm fine days of summer months this goes on. Humble-bees, honey-bees, insects in countless numbers, fly or creep and dive into flowers of all descriptions; and as they search for what they fwant, they carry off the loosened pollen, and give it over to other plants.

What the hive-bees want and search for is not always the same. Two especial needs have to be supplied: pollen, for what has been called "bee-bread," and sweet nectar, to be made into honey. When the workers leave their hive in the early morning, they seem to be "told off" for different tasks. One goes in search of pollen; another in quest of a supply of nectar; but never both at the same time.

A pollen-gatherer loads her little baskets - a curious arrangement of stiff hairs on her back pair of legs - and often gets her whole body covered as well with the golden stuff, before she returns to the hive. No light weight this, for so small a creature. Yet so soon as she is relieved of the burden by her sister-workers, she is off again for more.

But a nectar-gatherer has a lighter task. Her little baskets are useless when she goes hunting, not for honey, but for that which is to be transformed into honey. We all talk conventionally of insects getting " honey" from flowers. But honey, as we know it, is a " manufactured article" ; 1 and the "nectar " which the 1 Tickner Edwardes. 


\section{THE WORK OF WINDS AND INSECTS 147}

bee procures is a thin, sweet, watery liquid, only the raw material on which she has to work. The manufactory which does what is necessary is within her little body.

She has two small stomachs-so-called-one being the true stomach, while the other is a minute reservoir or "honey-sac," into which the sweet nectar which she sips is passed through a tube traversing her body. When she goes home with her sac full, having probably by the way used some as food, she gives over the contents to the empty sac of another bee; and by the latter it is stored in a cell. During such transferrings certain changes take place in its make, altering it from the original thin liquid into genuine honey, good for food of men.

In both these expeditions, which the bees are said to undertake by turns, perhaps on alternate days, they constantly help forward fertilisation, bearing pollen from plant to plant.

The question has been asked, "How is it that bees always carry away the right kind of pollen?" It naturally stirs up a counter question: "Do they, always?" At all events, they sometimes carry home honey-dew, instead of the right kind of nectar, for honey.

Authorities are not quite at one about this pollengathering. It has been confidently stated that they always carry one kind only at a time, and never mix different kinds; and that during a single excursion a bee will visit only one kind of flower, passing by all others. But a precisely opposite statement, founded on personal observation, is made in another and most weighty quarter. Again, in one direction we are told that, when they reach the hive the various kinds and colours of 
pollen are still kept separate in the cells; while in another direction we are informed that all the care of the bees is useless, since the different kinds of pollen are packed indiscriminately together in the cells.

A suggestion may perhaps be hazarded here that bees, or rather communities of bees, may not all follow the same plans. Some possibly may act in one way; some in another. It would be interesting to know if any evidence could be found of this.

In an earlier chapter something was said about the beauty of flowers, and the reasons why they may have been made so beautiful. Of one reason we need feel no real doubts; which is, that they might bring gladness and joy to us who live on the Earth.

But another and a very important reason, if not for their actual loveliness, yet certainly for their gay colouring, is that they may draw the attention of insects. If no insects came to visit them, we should have a sad dearth of pollen where it may be most urgently needed.

Though we can hardly suppose that insects love beautiful things as we do, simply for their loveliness, they are no doubt attracted by bright tints. Some of them are believed to possess what is called a "coloursense." In other words, they seem to know blue from yellow, pink from green. More than this, they even show signs of preferring one colour and disliking another.

It is said that a honey-bee loves a deep violet-blue, and has no objection to green or yellow, while she shows a marked avoidance of scarlet or orange-red. Whether any feeling of actual distaste is in question cannot be 
known with certainty. All we can be sure of is that, for some reason, she does not usually tackle flowers of those tints, but seems to keep away from them.

Somebody has suggested, as a possible explanation, that bees may suffer from "colour-blindness." Men are often more or less "colour-blind," and cannot distinguish certain hues, such as red from green. Possibly bees may have some such defect of vision, so that they cannot see red or orange-red blossoms; in which case, naturally, they would not go to them.

In a general way gay flowers do undoubtedly draw many insects. It is interesting to notice that those trees which depend chiefly on winds to carry about their dusty pollen, and which therefore do not need the help of insects, have usually small and dull flowers, easily overlooked. While plants which depend mainly on insect-visitors, have generally larger and brighter blooms.

Bees seem long ago to have discovered that what they want is more often to be found in the gayer flowers. How far this really has been due to "finding out for themselves," and how far to simple "instinct," it is impossible to say.

With most insects a large amount of instinct is found. By this we mean a kind of knowledge which is born with them, inherited by them, and not knowledge which is gained later through experience. But with such possession is also found a certain amount of power to learn from observation and practice. To decide in any particular instance exactly how far action has arisen from blind instinct, and how far from "finding out," is very difficult. 
Perhaps the only case known of Cross-Fertilisation being carried on by a warm-blooded animal, not an insect, is that of Humming-birds.

\section{III-Curious Contrivances}

Thus it becomes clear that, in the various plans found in Nature for the carrying of pollen from stamens to pistils, a good deal may be seen of hindering and of helping : of hindering the pollen from getting to the wrong pistils; of helping it to get to the right ones. That a flower should be fertilised by its own pollen is bad; therefore hindrances are placed in the way. That the pistils of one plant should be supplied with pollen from other similar plants is to be desired; therefore helps are provided.

A certain plant belonging to the south of Europe grows abundantly in ponds or in shallow waters of a lake; and with it may be markedly seen both the hindering and the helping. Like many others, this-the Vallisneria spiralis - has two kinds of flowers, the pistilbearing and the stamen-bearing. Its pollen is of a very sticky nature.

In mud at the bottom it has its roots; and long slender leaves grow upward, still under water. There too, the flowers quietly take shape; both kinds, pistilflowers and stamen-flowers, being sheltered safely inside sacs or bladders. Each pistil-flower is alone within its sac; and on a lengthening stem it rises and rises till the surface is reached. Then it opens out, with large petals and wide-tipped hanging pistils, to wait for the pollen which has to be brought to it. 


\section{THE WORK OF WINDS AND INSECTS 151}

After quite another fashion behave the stamen-flowers. They also take shape out of sight far below, encased in a bladder through which no damp may penetrate. But instead of only one flower, the sac contains many; and when they gain a certain stage, the enclosing sac opens to set them free. Then, in place of growing upward on a long stalk, they break short off and spring

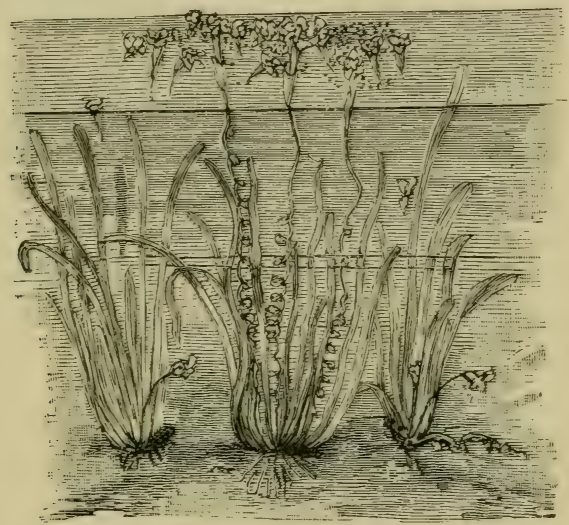

VALLISNERIA SPIRALIS.

to the surface, at the time when their pollen is just ripe.

On first arrival at the surface they are fast shut, and rounded like little globes; but soon they open, to float as tiny boats on pond or lake. Wonderful little boats, too-three flowers joined together forming one boat-supported by three outspread sepals, and so constructed as not to overturn even when blown about somewhat roughly. They have power to right 
themselves, and so to keep their precious pollen dry for use.

For use-but not for the use of those pistil-flowers which were grown on the same plant with themselves. In time these triple-boats, only two of the three having out-standing ripened anthers, as they are wafted about or even if no breeze stirs, are sure to gather round some of the pistil-flowers standing out of the water. Floating objects always do tend thus to draw together, through mutual attraction.

Some of the pollen-grains on board a tiny boat will then come into touch with one of the long drooping pistils, and will reach a waiting stigma; and, being sticky, will remain on it. Thus the needed work is done-so gracefully done too!-and Fertilisation is secured.

Nor is this all. We have scen how the pistil-flower grows upward from the bottom to the surface of the water, that its needs may be met. That being accomplished, its presence above is no longer called for. So the long stalk acts in an extraordinary manner. It shortens, coiling in a spiral, till the flower is again close to the bottom; there to ripen its seeds at leisure for the next year.

Did you ever watch a humble-bee trying to make her way into a Calceolaria flower? The entrance is rather complicated; but the bee, quite naturally, sits on the lower lip, and opens a door to herself by light pressure against the upper lip. A hidden " nectary," with plenty of sweet juice, then springs to view, "presented to the humble-bee, just like a spoon." When she has had 


\section{THE WORK OF WINDS AND INSECTS}

enough and departs, "the lower lip snaps to, and the nectary disappears from view." 1

But here also something else is pretty sure to happen. If the pollen within is ripe, she will be dusted over with it, and will leave some in flowers of a neighbouring plant.

We need not imagine that the bee understands the make of the flower, or knows that a certain pressure will cause the store of sweet stuff to come within her reach. Matters are so planned that she, taking her position at the entrance and trying to get in, will naturally exert such pressure. Still, when she has done it often, it is not impossible that she may remember how she got in before.

In much the same manner bees creep into the flowers of Foxgloves and Snapdragons. With the Wild Mustard a curious scheme is followed. The anthers are first bent towards the pistil; which might seem all right for the depositing of pollen on the stigmas. But when the pollen is nearly ripe, the stamens very curiously twist themselves round, till their faces are turned away from the pistil. Could speech say more plainly, "No, my pollen is not wanted there : it must go elsewhere, and pollen from some other plant has to come here"?

A second reason exists for this singular behaviour of the stamens. When a bee comes in for food, it so happens that the anthers as now placed-after the turnabout of the stamens-will brush her back with pollen. But if they had remained as they were before, she might have failed to carry any away. So the golden stuff which may not go to the pistils close at hand is borne away to other plants; and more bees, going first to those plants,

1 Kerner and Oliver, ii. 228. 
will bring some here instead; a very fair and wise exchange.

The Butterfly Orchis grows its pollen in two tiny lumps, close together. When a butterfly enters to feast on the sweet nectar, it oftens happens to press its forehead against these little lumps, which, being very sticky, remain attached like a new-fangled head-dress. But the visitor does not keep this burden long. Going into other flowers, it is pretty sure to press soon against a pistil-tip, leaving there part at least of the head-dress.

In all such Cross-Fertilisation work, done by winds and insects, as in the "Crossing" work of gardeners, not only is ordinary fertilisation carried on, but also the growth of fresh varieties is advanced.

Not that "Crossing" or "Cross-Fertilisation " will always account for such fresh varieties. Differences do appear from time to time, with no apparent reason; differences in size, in shape, in the form and colouring of flowers, in modes of growth. Plants are perpetually producing slight variations in their offspring; and the power to do so seems to be inborn. Fresh kinds, fresh types, are from time to time found in them, suddenly and unexpectedly.

This brings us naturally to a recollection of Darwin's favourite thought-" The survival of the fittest,"-by which he meant the survival of the strongest, of the healthiest, of the best-fitted to make their way in life. Such "survival" depends mainly on the plants' power of response and of self-adaptation to surroundings. A slight illustration of how this power works may be offered here. 


\section{THE WORK OF WINDS AND INSECTS 155}

Suppose that among a mass of Viola-plants growing together, one in particular has a greater capability than the rest to grow longer flower-stems; and that in consequence fuller sunshine is gained by its flowers than by those of any other plant in the group. As a result, those flowers will be more visited by insects, and will receive fuller supplies of pollen; so that, in the course of generations, this particular form of Viola will become more abundant than other and weaker kinds. Here at once is a very simple form of such "survival." The wonderful power seen in plants to adapt themselves to varying conditions seems sometimes to draw very near to actual animal-intelligence.

Gardeners can do a great deal for the producing of new forms; not, like insects, without understanding, but with deliberate intention. Countless new and lovely kinds have thus come into existence; and each year we have more and more of them.

Many years ago only the red form of the common Poppy was known. But the owner of a garden, where a bed of them grew, found one day among the rest a single blossom of a different hue. He at once marked it; and when it seeded he kept the seeds and sowed them apart. Then, when the young plants grew, he watched carefully till more of the unusual tints made their appearance; and again he marked these, kept the seeds, and grew fresh generations of plants, with pink and striped flowers, never seen before. They were named "Shirley Poppies," from the place where the selection occurred.

This probably was simply a natural development, a "Freak of Nature," not due to any "Crossing." 
"Evening rose from a bed of pain, And out of the west day dawned again; With outstretched fingers of falling light She touched the tree-tops and made them bright; And under the leaves, a-spark with dew, The cry of the blackbird sparkled too; And every hillock and glade and tree Was filled with the makings of melody, As the dying light streamed miles along Through murmur of water and leaf and song." 1

"And murmuring of innumerable bees," 2

1 From The Heart of Peace and Other Poems, by Laurence Housman, published by William Heinemann. By permission.

2 Tennyson. 


\section{PART $\mathrm{X}$}

SOME REMARKABLE WAYS OF PLANTS

\section{I-Plant Movements}

THE movements of plants, and of their various parts, are very curious. These alone would be enough to prove that they live. Things without life do not move and stir and turn round of themselves, any more than they grow or change in shape.

Something of the above we found in earlier chapters. We saw how a leaf or a flower will try to follow the sun in his daily journey across the sky; and this is true, not only of a leaf or a flower, for the whole plant generally is inclined to bend towards the sun, or towards the best light it can find. If we keep one in a window, and never turn the pot round, it will grow all to one side, and its shape is spoilt.

Again, we noticed how leaves and petals droop and close in dull weather, or when night is near. Not all in the same manner or to the same extent; for different kinds are as unlike in their ways as different people are unlike in theirs. Still, more or less and in one fashion or another, they all have their own little movements, regularly carried out.

Also, we saw how roots move, how the delicate tips circle about in their hunt for food. And it is the same with other parts. 
The stems, for instance-of some kinds certainly, and it may be true of all-go gently round and round, pointing a little towards the east, towards the south, towards the west, towards the north, and then toward the east again, so completing the circle, over and over again, day after day. And not only the main stem, but lesser stems which branch out from it, are believed to follow the same plan.

These movements are so very slight, so very slow and quiet, that they cannot be seen. They can only be made out by most delicate and exact measurements. Such measurements have been taken by those who have given their lives to the study of plant-life.

It is supposed, though not yet known with certainty, that each separate leaf may likewise carry on its own tiny movements, daily, in circles. Though we speak of "circles," the actual movements are believed to be, more strictly, not exact circles, but ovals-or what is known in Astronomy as "ellipses."

This fact, which probably is true of all plants, is much more markedly seen with Climbing Plants. If we examine one of them, we shall see how it twists in and out of a trellis-work or round and round the stem of another plant. And it does this in a most curious way. As the stem lengthens, its tip travels round and round in the air, hunting incessantly for something to lay hold of. Then, finding a support, it bends around that support, embracing firmly its new friend.

If you happen to live near a Hop-garden, you can, at the right season, study the growing Hops, and can see how they gradually mount and hold hard and hang in 
graceful festoons. Or you may find in the hedge a wild "Clematis,"-the "Traveller's Joy"-and again you will see much the same.

But such plants as the Bryony have extra help in climbing, for they grow tendrils, delicate spirals, which unwind and wind anew, and cling fast as they rise. The tendrils, like stem-tips, are ever going round and round, very gently, ever on the watch for a new support; and when they have come across what they need, they take resolute hold and refuse to let go.

While all stem-tips circle in this manner, they do not all move in the same direction. Those of the Scarlet Runner and of the Bindweed circle from west to east by the north; but those of the Hop and of the Honeysuckle circle from west to east by the south. It is practically the same difference as when the hands of a watch move forwards, or are made to move backwards.

Why this difference should exist we cannot say; we only know that so it is. And each plant keeps steadily to its own manner of moving, and will not consent to go the other way round, not even if it is so fastened as almost to force it to change. This has been tried; but the victim rebelled, and insisted on following the mode to which it was used.

Climbing Plants generally go upwards. They do not care to travel along a support laid flat on the ground. Some Creeping Plants grow thus; but a real Climber, if compelled to do so, gets out of health and sickly; for the life then lived is not natural to it. Mounting upward is its true nature; the nature of the life that is in it.

We may safely say that the tendrils, like other parts, are often, if not always, modified leaves. 


\section{II-Sensitive and Meat-eating Plants}

That all Vegetable Growths are more or less sensitive is pretty clear. They are sensitive to sunshine, to heat and cold, to moisture, to changes of climate and weather. We know how quickly they open their flowers to greet the sun, and how soon they droop from lack of water or of light and warmth.

By this word "sensitive" is meant generally the power to receive and to respond to impressions. It means with ourselves the power to receive light-waves, sound-waves, and any manner of touch; and to respond by the sensations of sight, of hearing, of feeling. Such sensations are often outwardly expressed by speech or movement; and a plant can respond by movement, though not by speech. These movements show us, not that the plant can actually see or hear or feel, but that it is in some way affected, that it is touched-disturbed or checked or helped-by outside influences.

A dog is standing in the road, and a motor-car spins suddenly round the corner. Instantly the dog jumps aside. That is his response to what suggests to him danger. The dog has brains and can think. He knows why he has hurried away.

A plant responds, but does not think, does not know why, which makes a very great difference. Still, the fact remains that it does respond. It is not like a rock or a stone. In its degree, it is sensitive to outer influences, to what goes on outside it and apart from itself.

And as some human beings are more sensitive, more easily stirred or startled, than others, so some vegetable growths are more quickly affected than others. A 


\section{SOME REMARKABLE WAYS OF PLANTS 161}

certain particular class is known by the name of "Sensitive Plants," because of their especially rapid response.

With one kind, a gentle wind blowing on the leaves, a few drops of rain, or even the touch of a finger, will cause a hurried folding together and drooping; much as other leaves will do slowly at the approach of night. A particular species, growing in India, is so excessively sensitive, that even a touch is not needed. ${ }^{\mathbf{1}}$ It is enough for a man simply to come near; and the slight stir of air caused by his movements will make the leaves shrink and fall, as if in alarm.

Years ago I saw in Kew Gardens a singular example. It was the Telegraph Plant from Bengal, ${ }^{2}$ a small thing in a pot, with slim pointed leaflets. Outward touch had no effect, but as we stood looking one leaflet here or another there would suddenly drop, like a railway signal falling to announce a train. Then, I was told, each would gradually rise to its old position soon to drop again. No cause was known to which these movements could be traced, but they were found to be more frequent with greater heat.

Many sensitive plants grow in tropical countries, and one of them, a Mimosa, has delicate leaves, which respond prettily on the smallest provocation. First the leaflets droop, then with speed the whole leaf-stalk falls limply. In such cases we do not find the slowness of movement common in plant-life.

By far the greater number of these curious growths belong to foreign countries. But the little Wood-sorrel

1 Oxalis sensitiva.

2 Desmodium gyrans. 
of England shows the same tendency. Its leaves will shrink slightly with rough handling, or if touched in a certain manner with the blade of a penknife.

"A Sensitive Plant in a garden grew, And the young winds fed it with silver dew, And it opened its fan-like leaves to the light, And closed them beneath the kisses of night.

"And the spring arose on the garden fair, And the Spirit of Love fell everywhere; And each flower and herb on Earth's dark breast Rose from the dreams of its wintry rest.

"But none ever trembled and panted with bliss In the garden, the field, or the wilderness, Like a doe in the noontide with love's sweet want, As the companionless Sensitive Plant.

"The snowdrop and then the violet, Arose from the ground with warm rain wet, And their breath was mixed with fresh odours, sent From the turf, like the voice and the instrument.

"Then the pied wind-flowers and the tulip tall, And narcissi, the fairest among them all, Who gaze on their eyes in the stream's recess, Till they died of their own dear loveliness.

"And the hyacinth purple and white and blue, Which flung from its bells a sweet peal anew Of music, so delicate, soft and intense, It was felt like an odour within the sense.

"Each and all like ministering angels were For the Sensitive Plant sweet joy to bear, While the lagging hours of the day went by Like windless clouds o'er a tender sky.

"And when evening descended from heaven above, And the earth was all rest, and the air was all love, And delight, though less bright, was far more deep, And the day's veil fell from the world of sleep. 


\section{SOME REMARKABLE WAYS OF PLANTS 163}

"The Sensitive Plant was the earliest

Upgathered into the bosom of rest;

A sweet child, weary of its delight,

The feeblest and yet the favourite,

Cradled within the embrace of night." 1

Another kind is marked by another sort of sensitiveness, by what looks very much like sense. There are plants which actually feed on solid animal-food. This is a remarkable exception.

In the chapters on Roots and Leaves we saw that "vegetables" in general, using the word in its widest sense, are able only to take in liquid food, or food in the form of gases. Not one of them could receive or digest anything solid. Yet here we find that rule apparently broken.

No less than five hun-

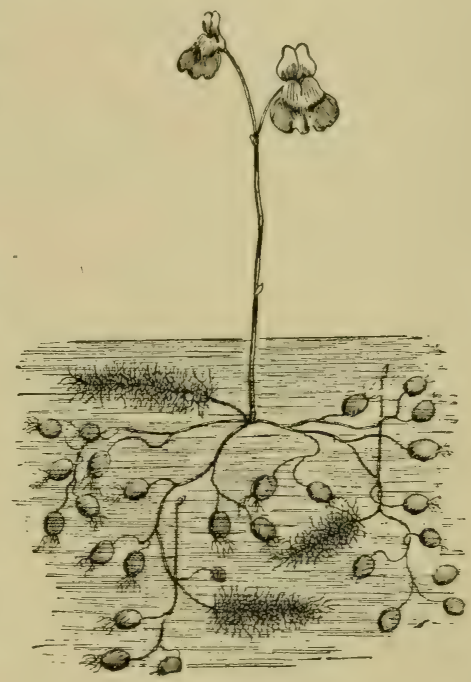

BLADDERWORT. dred kinds are known, in various parts of the world, which more or less live on animal-food, taken in the solid form. They are often called "Insectivorous Plants," because they subsist largely on insects; and also sometimes they are described as "Flesh-eating."

Such food is captured by them in many ways, and only two or three can be mentioned here.

1 Shelley. 
A large number belong to the group of Bladderworts.

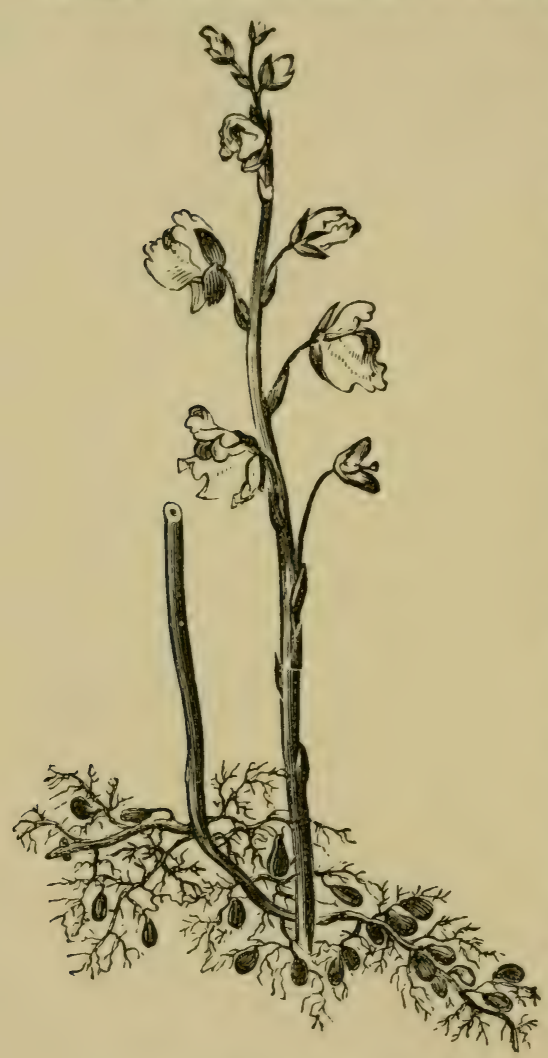

UTRICULARIA VULGARIS (Common

Bladderwort).
They live in water, and have curious little bladders, which in springtime rise to the surface, and there float, acting as traps for the unwary. Each bladder has one tiny opening, closed by valves, and it can be entered from outside, but not quitted from the inside.

Small creatures, such as the young of gnats and worms, force their way in through protecting bristles, perhaps out of curiosity, perhaps in search of food, perhaps only to escape pursuing foes-and once in they have to stay, for the valves cannot be opened from within. They may live in their prison for hours, or even for days, but in the end they die, and are digested.

Then there are the remarkable Pitcher-plants of 
California, and other tropical parts. Beautifully shaped hanging pitchers grow on them, partly filled with liquid. These, too, act as traps. Creatures fall, or fly, or creep into them, to be caught and held fast until they die, when again they are slowly digested.

One of the commonest and best-known of such plants is the Sundew, ${ }^{1}$ widely spread through North Europe and North America. It grows usually on exposed moorlands, and also in some very cold regions.

Here it is the leaves which act as traps. Each leaf lies flat on the ground, in shape slightly "trough-like" and very sticky. Any small insect alighting there is caught and held firmly, despite all its struggles.

At the first touch of a victim the leaf begins to pour out juices from the little glands, which have power to manufacture such juices, and

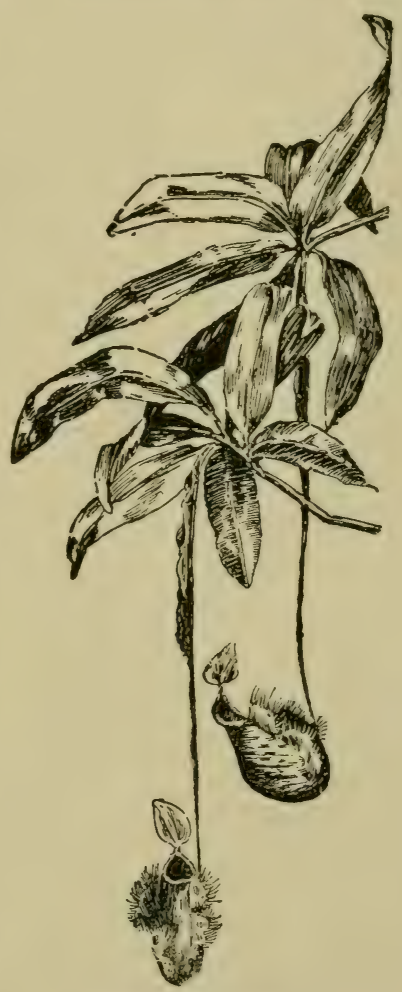

PITCHER-PLANT. its edges turn slowly and ruthlessly up, curling over so as to imprison the unfortunate prey-once more to 1 Drosera. 
serve as meat for the plant. About twenty-four hours later, if it is a quite small insect, the leaf uncurls and is ready for another victim, though digestion often takes much longer.

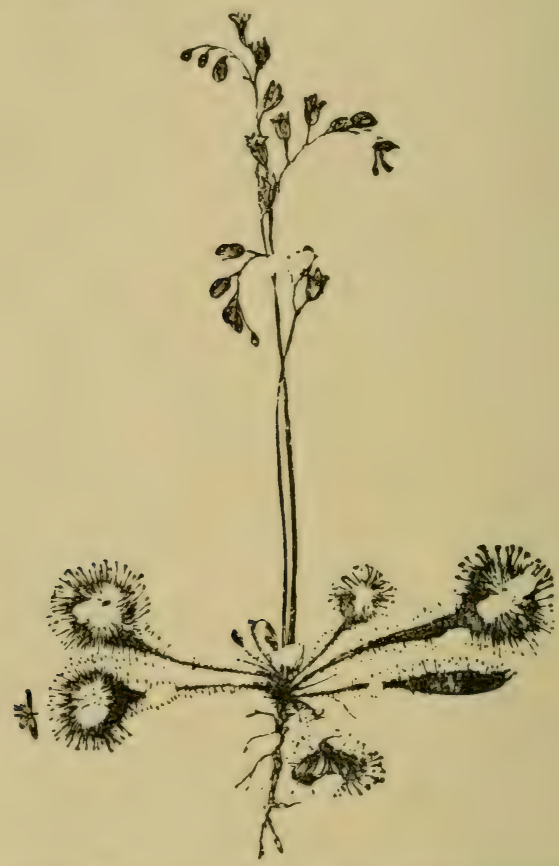

Drosera rotundifolia (Round-leaved Sundew).

A tiny scrap of meat placed there will be treated in a like manner, taken captive, well soused in juice, and gradually disposed of. Midges, ants, beetles, and small butterflies, are perhaps the commonest items of Sundew fare, though, as we have seen, it seems to like variety. 


\section{SOME REMARKABLE WAYS OF PLANTS 167}

Often seeds and pollen-grains are wafted thither, for the same purpose.

If a dragon-fly happens to be captured, that is a grand haul. One or two more leaves will then come bending over to help the captor, for extra strength is needed to hold such a vigorous captive, and more juices for his complete subjection than a single leaf can supply.

Yet another Insect-eating plant is the "Venus' Flytrap," a native of North America. Here again the leaves are the traps. Sharp spines grow on them, and when an unfortunate insect alights there, it is caught at once by the sticky outflow. Then it is closed in upon, slowly, pitilessly, the sharp spines crossing till its imprisonment is complete. Sometimes the leaf will remain tightly shut for a week, a fortnight, or even three weeks.

And these are only a few of the extraordinary "Fleshdevouring Plants" now known to botanists.

\section{III-The Health of Plants}

We often speak of plants as being healthy or unhealthy, just as we speak of human beings; and it is the simple truth that they, like ourselves, may be either well or ill, either feeble or vigorous. They suffer from illnesses and diseases, much as we do, and often from the same causes.

It may be bad air which upsets them, or want of good water to drink, or insufficient food in the soil, or not enough sunshine, or too much heat or too much cold. One kind needs what another cannot stand. So with us - "one man's meat is another man's poison."

Mention has been made earlier of growths which do not root in the ground, but drain their nourishment 
from some other plant upon which they live. Parasites of various kinds are common in the Vegetable World, and they are usually looked upon as hurtful, as bringing discase, if not death, to the tree or herb attacked.

The smallest and most abundant of these unwelcome guests are the Bacteria-tiny invisible hordes! We spoke of them as among the very lowest on the rungs of a ladder of vegetable growths. It is not certain that all the Bacteria are "vegetable" in nature, for some may be "animal," but at least very many of them are. And their numbers are simply enormous, far beyond our power to reckon.

Not much has been said, so far, about the quantities of Seeds, which can be produced by a flowering plant in one season. These quantities differ immensely, for some plants bring forth very few, perhaps one or two seeds only to a single bloom. But they are rather rare, and with others matters are widely the reverse.

For instance, a single plant has been known to grow ten thousand seeds in a year; another sixty thousand; another a hundred thousand; another seven hundred thousand; and so on.

And if each of those thousands of seeds should produce next year another ten or a hundred thousand, and each of those again the same amounts in the year after-think what it would all come to. Naturally, they do not, because many seeds must always fail, from want of water or of room to grow or some other cause.

So much for the manufacture of seeds by flowering plants. But when we go down the ladder to the swarming Bacteria, these numbers are far surpassed. Here we 
find nothing in the shape of seeds, but more generally growth by each individual dividing into two.

And very quickly it comes about! You would hardly believe, unless you already know it, how rapidly these tiny atoms of life get through what we describe as "growing up." When careful watch had been kept over some of them-of course through a microscope-it was found that in twenty minutes they had so reached maturity as to divide again.

With human beings a "generation" is supposed to last about thirty years. But with these minute beings a "generation" seems to last less than half-an-hour. And this, at such a rate of increase, means that in the course of about eight hours some sixty millions of them might come into existence, all descended from one small ancestor.

So no wonder that there are plenty, and more than plenty, of them !

Plants suffer from many different kinds of disease. But when we use the word "suffer," we do not mean that they actually endure pain. The plant, as a plant, loses health and vigour and beauty. Whether it is in the very faintest degree conscious of its loss is another question.

We all know of the Potato Disease, and many among us can remember the terrible famine in Ireland, which followed its outbreak. For at that time the poor of Ireland lived mainly on potatoes, and when they failed nothing remained.

Most of us, too, are familiar with the small round objects called "Oak-apples." But they are not apples. 
They are a disease of the Oak-tree. Such gall-growths are found on other plants as well, and they are usually due to a small living creature getting inside the stem, or branch, and staying there, while an unhealthy lump forms round it.

Often we see upon the trunk of a tree a large unsightly swelling, and this again means disease. With a tree, happily, it does not mean pain, as any such growth would with a man, but it does mean that the health of the tree is not what it should be.

One well-known parasite is an odd little red plant, called the "Dodder," which goes creeping over others, sucking its food from them, and never taking the trouble to send a root into the earth. One may often see the Dodder crawling over bushes on a common.

And though usually we look on such parasites as hurtful to the plants upon which they fasten, yet it may not be so in every case. For, with regard to the "galls" just mentioned, it has been found, curiously, that in growing thus they have sometimes caused the single flowers of the plant attacked to become double; the stamens altering into petals. You know how the single flowers of a Wild Rose may become double through cultivation. Here the same thing is believed to come about, not through a gardener's care, but through that which is more in the nature of a disease.

And this does not stand alone. A botanist, who studied the matter closely, found in certain instances that a parasite, preying on the roots of a plant, instead of doing it harm seemed actually to do it good. The plant which was preyed upon, far from being weakened, grew more strong and healthy. 
So in the Vegctable World, as in our world, it sometimes happens that those things which are looked upon as most sad may in the end bring about greater good.

\section{IV-Plant-Life in General}

We have seen in these pages some wonderful things about the Vegetable World. We have learnt a little of how its members live; how they breathe, how they feed, how they rest, how they seem to love sunshine. We have found how they differ in their ways and in their likings - if that word may be used for them-and in the kinds of soil and air and climate that they need.

Something we have noticed of what they have to do in our world: of the work of Roots, the work of Stems, the work of Leaves, the work of Flowers.

More than this, it has become clear how truly they live; how utterly they differ from things without life; how much more nearly they are related to ourselves than perhaps we have imagined.

Also we have seen how tremendously useful they are to mankind, more than useful, absolutely necessary, since apart from the marvellous tasks which they carry out we could not live. So we may well look on them with gratitude : gratitude first to Him Who gave them to us; gratitude also to themselves, our faithful servants, ever busied for our benefit. We may think of them as our small brother and sister beings, to be loved and admired and cared for.

And all the while we know so little of their real nature; of how and in what manner they do the extraordinary things that we see them do. 
Why should the roots rove hither and thither in search of the right food? Why should flowers and leaves turn persistently towards the sun? Why should the Vallisneria stalk act as it does-growing up to the watersurface for supplies of pollen, then bending and coiling downward, to be ready with ripened seeds for the next year? Where lies the connection between such actions and the unseen cause, the hidden controlling power? What is that cause-that power?

Such questions we cannot answer fully. We cannot define how far that which we call " sense" or " sensitiveness" on the part of plants is actually what we mean by the words. We only know that in many ways they behave almost as if they really had a measure of understanding.

Not of understanding like our own. Not of understanding equal to that of animals. This we cannot suppose.

But in recent years the thought has gained ground that perhaps-perhaps-in the mysterious world of plant-life a very faint measure may exist of something like "consciousness." That when they seem to shrink from a touch, when they droop and fail from lack of sunshine or of water, there may be in them the tiniest amount of something like discomfort. That when they gaze up at the sun, and appear to bask in his rays, they may have a dim sense of enjoyment, or at all events of something akin to satisfaction. We are certainly free to indulge in the fancy, and in time we may know that it is not only a fancy.

The word just used, "consciousness," needs defining. I think that what we mean by it in this connection is- 
not only being alive, but knowing that one is alive. We ourselves live, and we know that we live. A plant lives; but can we contend that in the feeblest degree it knows that it lives? There lies the real question! And though we constantly talk of plants as if they knew, as if they understood, as if they did certain things for certain ends, knowing why they so act, it is not without a touch of reservation that we quote Wordsworth's couplet-

"And 'tis my faith that every flower

Enjoys the air it breathes."

Not that the words may not be perfectly true, but that perhaps we cannot yet be sure.

To return to the main question: How do these things, these growths, movements, adaptations, changes, developments, come about? By what power, through what control, are they caused?

"Nature," we are told, does this, and brings to pass that. But the answer does not satisfy. "Nature" is not a person, is not even a power. "Nature" means simply the sum of all that we see and know to be going on around us; possibly not including inanimate rocks and stones, but certainly including animal-life and plantlife of every description, and all human life. When we speak of "Nature" working changes in plants, we might just as well speak of their doing it themselves.

Nor would this, in a sense, be wrong. Not consciously - yet actually - they do it.

Some animals, in cold northern winters, change the colour of their coats from brown to white, a protective 
act, rendering them invisible against the snow. We cannot suppose that the will of the creature works this alteration. It is due to the subconscious Life which controls the creature's body.

When your heart beats day and night persistently, it is not you-not the conscious part of you-which keeps that heart going and regulates its beating. Here, again, the unconscious or subconscious Life in you does the work. Your soul controls your body; consciously in part, unconsciously in part. The "soul" or "life" 1 may be said in a manner to know what is needful for your body, and to bring about, so far as it can, what is needed, apart from any effort of your conscious will.

In like manner the life-the soul-of an animal controls its growth and developments, and does all in its power to bring about what is required for the good of the animal, quite irrespective of the latter's will. When we talk of the "healing power of Nature," as seen in a wounded body of man or animal, it is this to which in reality we are referring.

And so too, though in a much lower degree, may we not claim for the Plant a "soul" or "life" which does its utmost to obtain all that the plant craves for or needs to keep it in health? As the "life" of the coralpolype secretes and builds the solid framework on which it dwells, so the "life" or "soul" of a plant secretes and builds the framework of that plant, controls its actions, and fosters its developments. ${ }^{2}$

1 One Greek word stands for both "soul" and "life," and may be translated by either.

${ }_{2}^{2}$ It may be asked-If plants and animals consist, like Man, of body and soul in even very limited degrees, are they to be regarded as in the same category with Man?-are they all mare 
But beyond and behind and throughout all this, as we well know, dwells ever One Supreme, "The Lord and Giver of Life," -

\section{"the Power}

That rules all action and all tides of thought, And all the secret courses of the Stars." 1

One matter, much discussed during recent years, has not yet been mentioned. This is the extraordinary fulness and abundance of Vegetable Life on Earth, together with the thought of conflict, and of the incessant struggle for existence. In other words, the way in which each seed, each plantlet, has to fight for very life, and can only prevail by getting the better of others in the strife.

No portion of Earth's surface can support more than a certain amount of vegetation; and where one seed or one plant succeeds, many others are bound to fail.

To some extent such a condition of things is inevitable. Where hundreds of seeds have ripened, only a limited number of them can become healthy and wellgrown plants. Many must fail, from lack of room and of food.

If we think once more of the acorns seen on a single Oak, we shall realise how few of them will ever become large trees. At any particular place only enough food is found in the soil to keep going a definite number of Oaks; and where one survives others must die.

Certain writers, seeing this vividly, have spoken in a

or less on the same level? No; for Man is not body and soul only; he is Body, Soul, and Spirit. Man alone was made " in the Image of God."'

1 Alfred Noyes. 
melancholy key about plants as selfishly fighting for themselves, and ruthlessly trampling out the lives of their companions. Much has been written as to the "fierce struggle" going on, and the many that perish, neglected and forgotten failures.

That is not, however, a very happy way of looking on the matter, and it may be viewed from another standpoint.

We need not blame the plants which succeed, since we ourselves imperatively need them to work for us, to purify our atmosphere, to prepare our daily food. And they have to carry out these duties, to which they are called.

As for the seeming failures - the unused seeds, the wasted acorns, the dying plantlets-they are not really wasted or useless or failures. They have their simple tasks to perform, even though they can never add to the number of our stately forest-trees.

Sometimes they serve as food for man. Sometimes they serve as food for animals. Sometimes they help to enrich the soil in which more successful growths will find a home; and so they end by becoming food for future generations of Vegetable Life.

And if many multitudes of these-of pollen-grains, of seeds, of plantlets-have to fulfil such humble ends, have to give up their little lives for others, dying unnoticed and unknown, instead of becoming what they seemed to have been made for, and what they set out to be-neither they nor we have any right to complain. It is all part of the same great Service! Many kinds of plants, and many types of service, are needed for such a "Garden" as our Earth. 


\section{INDEX}

ACORNS, 133, 175

Animal kingdom, 16, 27

Annuals, 124

Anther of stamen, 118, 137, 153

Bacteria, 71, 168

Banana-plant, 109

Banyan-tree, 27, 38

Beauty of flowers, 19-21, 148

Beech, 38

Bees, 143-8, 152, etc.

Beetroot, 107

Biennials, 124

Bindweed, 159

Bladderworts, 164

Bracts, 53

Brain of plant, 73

Bread, 105

Breathing of plants, 87-90

Bryony, 159

Budding, 119

Bulbs, 39, 125, 129

Butter, 106

Buttercup, 40, 53-4

Butterfly Orchis, 154

Calyx, 22, 56, 118

Camphor-tree, 110

Candytuft, 5

Catkins, 139

Cedar of Lebanon, 38

Celery, 58

Cells and tubes, 30, 69, 70, 78-80, 91, 93

"Character" in plants, 123

Cheese, make of, 106

Chlorophyll, 94, 113

Classification, 44-7

Clematis, 159

Climbing plants, 159

Cocoa or Cacao, 108

Cocoa-nuts, 135

Compositæ, 57

Contrivances, 150-5

Corolla, 22, 118

Cotton-plant, 109

Cotyledons, 39-42

Crocus bulbs, 125

Cross-fertilization, 137-9, 143-6, 152-4

Crossing, 138, 154-5

Daffodil, 127

Daisies, 2, 5, 7, 56, 96

Dandelion, 57,134
Date-palm, 108

Diatoms, 30-1, 112

Digestion of plants, $87-90$

Divisions or Classes, $27,36,39-42$

Dodder-plant, 170

Earth a Garden, 26

Elm, 29, 41

Families, 36, 46-9

Fern-fructification, 33-6

Ferns, 33-6

Filament, 118

Flax-plant, 110

Flowering plants, 26, 29-30, 36

Flowerless plants, 33,36

Flowers, 18-21, 114, etc.

- parts of, 21 , etc., 117 , etc.

- scents, 116

- varieties of, 114

- work of, 19, 114-36

Food of plants, $70-5$

Food, Vegetable, 14, 19, 94, 105-9

Fools' Parsley, 58

Forget-me-not, 5

Foxglove, 153

Fronds, 33-5

Frost, work of, 63

Fruits, 108-9

Genera, 47

Germination, 130

Grand St. Bernard, 62

Grasses, 36, 40, 142

Growth of plant, 10, 12

Hazel-tree, 142

Health of plants, 97, 167, 169

Hemlock, 58

Hive-bee, 146-9

Honeysuckle, 159

Hop, 159

Humble-bee, 144, 152

Insect-help, 138, 142-50

Insectivorous plants, 163

Instinct in animals, 149

Leaf-green. See Chlorophyll.

Leaves, 18, 39-42, 82-95, 100-2. See Modified leaves. colouring of, 92-4 make of, 41,85 , etc. 
Leaves, numbers of, 84 13 work of, $19,82,84,88-95,102-$

Lichens, 32

Life of plants, $14,67,81,84,92,121$, 159,174

Lilacs, 5

Lily, 40

Manufactures, 82-5, 102-10

Meat-eating plants, $163-7$

Mimosa, 161

Modifled leaves, 22-5, 159

Mosses, 33

Movements of plants, 71-3, 157-62

Narcissus, 40

Natural Orders, 47

Nature, 173

Oak, 38, 41, 84, 87, 133, 175

Oak-apples, 169

Oats, 36

Ocean-animals' food, 110-13

Onion, 96

Orange, 108

Orchids, $40,66,87,138$

Organic substance, 84

Ovary, 118,120

Ovule, $120-2$

Palms, 38, 41

Papaveraceæ, 55

Pear, 51, 108

Perennials, 124

Petals, 22, 117-9

Phlox, 5

Pistils, 23, 25, 118, 120, 122-5

Plant-manufactures, 82-5, 102-5

Plums, 109

Pollen, 23, 118, 122-3, 137-42, 146-55

Polyanthus, 5

Poppy, 155

Potatoes, 126, 129, 169

Primroses, 5 , 40

Radish, 125

Raflesia Arnoldi, 115

Ranunculaceæ, 54

Raspberry, 51

Receptacle, 51

Relationships, 36, 46-7, 48-60

Resurrection of spring, 131

Rice, 108

Roots, 18, 66-7, 157

Root-tips and hairs, $68-75$

Rose, 5, 10, 21-5, 48

Rose Family or Order, 48-52

Salt, 105

Sap, rise of, 76-81, 104

Scarlet Runners, 159
Seaweeds, 33

Seed-leaves. See Cotyledons.

Seed-scattering, 132

Seeds, 2, 19, 24, 119, 121, 126-31, 168, 175

Sensitive plants, 160-7

Sepals, 22, 51, 118-9

Shirley Poppies, 155

Silk, 110

Sleep of plants, 8, 101, 128, 157

Sling-fruits, 134

Snapdragon, 153

Snow, red, 30

Snowdrop, 125

Soils, 61-5, 72, 103

"Soul," 174

Species, 47

Spores, 35,63

Stamens, 23-5, 53, 118, 153

Stems, 18, 74, 158

Stigma, 118

Stomata, or leaf-pores, 86-8

Storage of food, 124-7

Strawberry, 50

Style, 118

Sugar-cane, 36,107

Sun, power of, $6,75,94-100,121,129-31$

Sundew, 165-7

Sunflower, 57, 96

Survival theory, 154

Tea, 108

Telegraph-plant, 161

Tendrils, 159

Tiger-lily, 138

Tips of roots, 68

Transpiration, 87,90

"Tribes," 47

Tubes. See Cells and tubes.

Vallisneria spiralis, 150-2

Variegated Laurel, 124

Vegetable kingdom, 14, 16, 27, 29, 38, $105,109,117,128,171$

Venus' Fly-trap, 167

Viola, 97-100, 155

Violets, 5

Volvox, 31

Water-plants, 135

Water-vapour, $80,87,91$

Wellingtonia, $27,37,38$

Wheat, 105

Wild Miustard, 153

Wind and water, 134-5, 141

Winter-work, 4, 74-5, 128-31

Wood, make of, 103-4

Wood-sorrel, 161

Wool, 109

Work-shops, 19, 82, 92-3, 116, 137

Worms, work of, $4,64-5$ 




\section{New York Botanical Garden Library}

QK50.G49

Giberne, Agnes/The garden of earth, a li

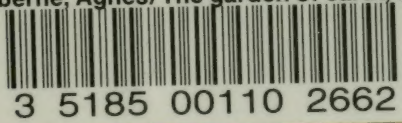


